\title{
DNFSB Recommendation 94-1 Hanford Site Integrated Stabilization Management Plan
}

Date Published

October 1995

Prepared for the U.S. Department of Energy Office of Environmental Restoration and Waste Management

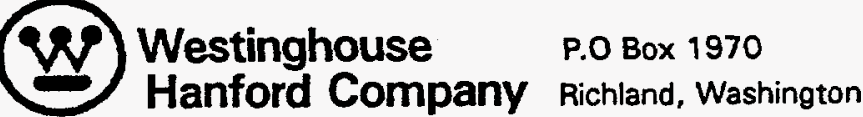

Hanford Operations and Engineering Contractor for the

U.S. Department of Energy under Contrect DE-AC06-87RL10930 


\section{DISCLAMMIR}

Portions of this document may be illegible in electronic image products. Images are produced from the best available original document. 


\section{RELEASE AUTHORIZATION}

Document Number: WHC-EP-0853, Rev. 1, Volumes 1 and 2

Document Title: $\quad$ DNFSB Recommendation 94-1 Hanford Site Integrated Stabilization Mangement Plan

Release Date: $\quad 10 / 27 / 95$

This document was reviewed following the procedures described in WHC-CM-3-4 and is:

APPROVED FOR PUBLIC RELEASE

WHC Information Release Administration Specialist:

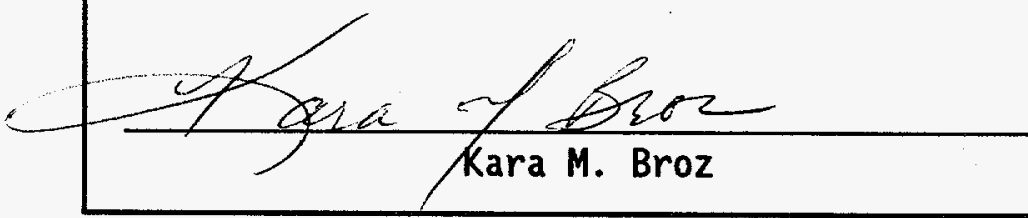


WHC-EP-0853 REV. 1

\section{DNFSB RECOMMENDATION 94-1 \\ HANFORD SITE INTEGRATED STABILIZATION \\ MANAGEMENT PLAN}

\section{EXECUTIVE SUMMARY}

The U.S. Department of Energy (DOE) has developed an Integrated Program Plan (IPP) to address concerns identified in Defense Nuclear Facilities Safety Board Recommendation 94-1. The IPP describes the actions that DOE plans to implement at its various sites to convert excess fissile materials to forms or conditions suitable for safe interim storage. The baseline IPP was issued as DOE's Defense Nuclear Facilities Safety Board (DNFSB) Recommendation 94-1 Implementation Plan (IP), which was transmitted to the DNFSB on February 28, 1995. The IPP is being further developed to include complex-wide requirements for research and development and a long-range facility requirements section. The planned additions to the baseline IPP are being developed based on a systems engineering approach that integrates facilities and capabilities at the various DOE sites and focuses on attaining safe interim storage with minimum safety risks and environmental impacts.

Each affected DOE site has developed a Site Integrated Stabilization Management Plan (SISMP) to identify individual site plans to implement the DNFSB Recommendation 94-1 IPP and to provide a basis for formulating planned additions to the IPP. The SISMPs were developed based on the objectives, requirements, and commitments identified in the baseline DNFSB Recommendation 94-1 IPP. The SISMPs will be periodically updated to reflect improved integration between DOE sites as identified during the IPP systems engineering evaluations.

This document constitutes the Hanford SISMP. This document includes the planned work scope, costs and schedules for activities at the Hanford Site to implement the DNFSB Recommendation 94-1 IPP.

Materials within the scope of this SISMP include spent nuclear fuel (SNF) and plutonium-bearing materials currently located at the Hanford Site. The Hanford Site SISMP is comprised of two volumes. Volume 1 identifies the plans for placing these materials in safe interim storage, and Volume 2 provides integrated schedules for completing the planned work scope identified in Volume 1. 
The plans identified in the Hanford SISMP will result in removal of SNF from the 105-K Basins by December 1999, consistent with the DNFSB's recommendation "that the program be accelerated to place the deteriorating reactor fuel in the $K$-East Basin at the Hanford Site in a stable configuration for interim storage until an option for ultimate disposition is chosen." The plans also result in achieving dry interim storage of the SNF by June 2000. Additionally, the plans will place Hanford Site plutonium-bearing materials in safe interim storage by May 2002.

The cost of achieving safe interim dry storage of the 105-K Basins SNF is estimated at $\$ 468$ million. This cost is based on current budget estimates and includes the costs to retrieve, transport, stage, condition and implement dry interim storage (i.e., characterize SNF, acquire facilities, etc.) and disposition 105-K Basins sludge. The projected cost to store the 105-K Basins SNF until dry interim storage is achieved is $\$ 623$ million. This cost includes operations at the 105-K Basins in addition to the costs to achieve safe interim dry storage. The \$623 million estimated cost does not include the program costs associated with 105-K Basins deactivation. These costs are based on remaining costs for the activities from the beginning of fiscal year (FY) 1996 until completion.

The cost to achieve safe interim storage of the plutonium-bearing materials is estimated at $\$ 145$ million to $\$ 160$ million. This plan assumes that DOE will reallocate resources to provide the budgets necessary to attain safe interim storage within schedule commitments. 


\section{TABLE OF CONTENTS}

1.0 INTRODUCTION $\ldots \ldots \ldots \ldots \ldots \ldots \ldots \ldots \ldots \ldots \ldots \ldots \ldots \ldots \ldots \ldots \ldots .1$

1.1 BACKGROUND $\ldots \ldots \ldots \ldots \ldots \ldots \ldots \ldots \ldots \ldots \ldots \ldots \ldots \ldots \ldots \ldots .1-1$

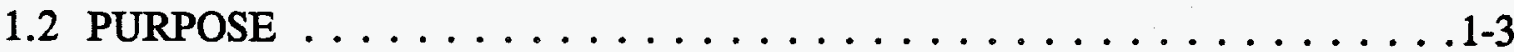

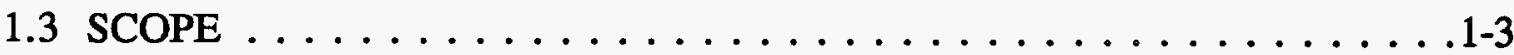

1.4 ORGANIZATIONAL RESPONSIBILITIES $\ldots \ldots \ldots \ldots \ldots \ldots \ldots \ldots$

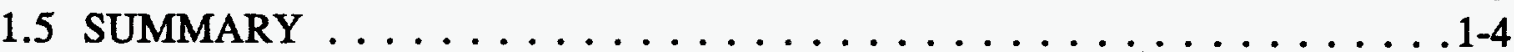

2.0 HANFORD SITE SPENT NUCLEAR FUEL $\ldots \ldots \ldots \ldots \ldots \ldots \ldots \ldots$. . . . . . . .

$2.1105-\mathrm{K}$ BASINS SPENT NUCLEAR FUEL $\ldots \ldots \ldots \ldots \ldots \ldots \ldots .2-1$

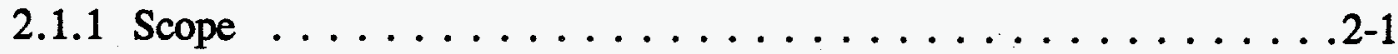

2.1 .2 Remediation Objective $\ldots \ldots \ldots \ldots \ldots \ldots \ldots \ldots . . \ldots \ldots$

2.1 .3 Remediation Process . . . . . . . . . . . . . . . 2-4

2.1.4 Schedule Objectives . . . . . . . . . . . . . . 2-9

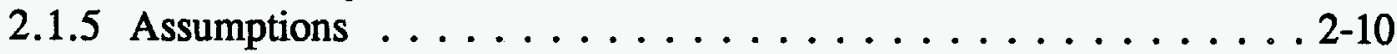

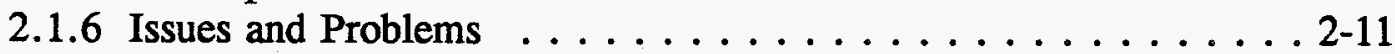

2.1 .7 Alternatives . . . . . . . . . . . . . . . . 2-11

2.1.8 Technology Development . . . . . . . . . . 2-13

2.2 OTHER HANFORD SITE SPENT NUCLEAR FUEL $\ldots \ldots \ldots \ldots \ldots$ 2-15

2.2 .1 Scope . . . . . . . . . . . . . . . . . 2-15

2.2.2 Remediation Objective $\ldots \ldots \ldots \ldots \ldots \ldots \ldots \ldots \ldots \ldots$ 2-16

2.2.3 Remediation Process $\ldots \ldots \ldots \ldots \ldots \ldots \ldots . . \ldots$. . . . . . . . .

2.2.4 Schedule Objectives . . . . . . . . . . . . . 2-22

2.2 .5 Assumptions . . . . . . . . . . . . . 2-22

2.2.6 Issues and Problems $\ldots \ldots \ldots \ldots \ldots \ldots \ldots . \ldots . \ldots .223$

2.2 .7 Alternatives . . . . . . . . . . . . . . . 2-23

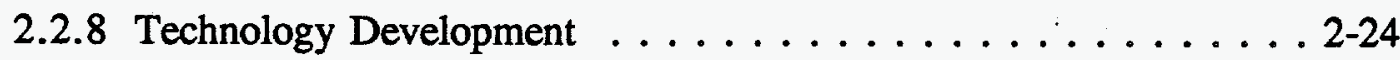

2.3 RESOURCES . . . . . . . . . . . . . . . . . . 2-24

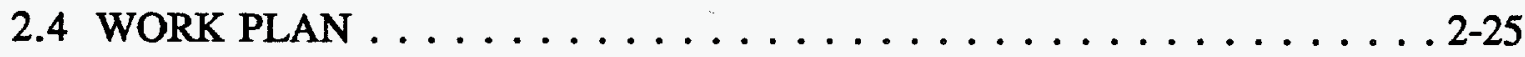

2.5 STAKEHOLDER INVOLVEMENT $\ldots \ldots \ldots \ldots \ldots \ldots \ldots \ldots \ldots$

3.0 PLUTONIUM-BEARING MATERIALS $\ldots \ldots \ldots \ldots \ldots \ldots \ldots \ldots$. $\ldots \ldots \ldots$

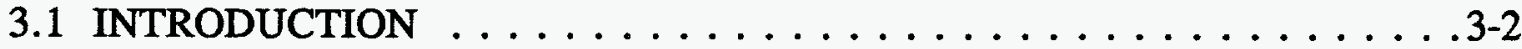

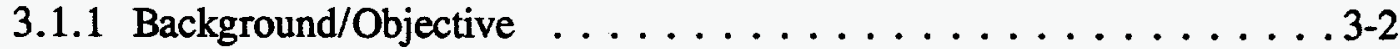

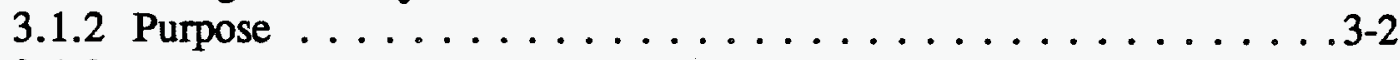

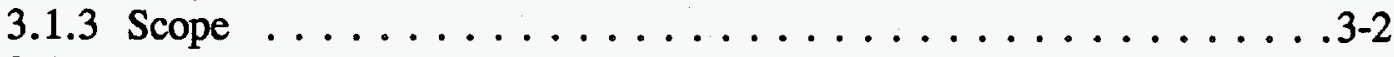

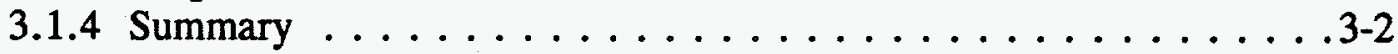




\section{WHC-EP-0853 REV. 1}

3.2 SOLUTIONS $\ldots \ldots \ldots \ldots \ldots \ldots \ldots \ldots \ldots \ldots \ldots \ldots \ldots \ldots \ldots . . \ldots \ldots \ldots$

3.2 .1 Scope $\ldots \ldots \ldots \ldots \ldots \ldots \ldots \ldots \ldots \ldots \ldots \ldots \ldots . . \ldots \ldots$

3.2.2 Remediation Objectives $\ldots \ldots \ldots \ldots \ldots \ldots \ldots \ldots \ldots . . . .4$

3.2.3 Remediation Process . . . . . . . . . . . . . . 3-10

3.2 .4 Schedule Objectives $\ldots \ldots \ldots \ldots \ldots \ldots \ldots \ldots \ldots \ldots$. . . . . . . . .

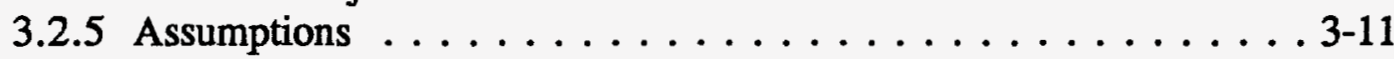

3.2.6 Issues and Problems $\ldots \ldots \ldots \ldots \ldots \ldots \ldots . \ldots \ldots$ 3-12

3.2.7 Alternatives/Impacts $\ldots \ldots \ldots \ldots \ldots \ldots \ldots \ldots \ldots$. . . . . . . . . .

3.2.8 Technology Development $\ldots \ldots \ldots \ldots \ldots \ldots \ldots$. . . . . . . . . .

3.3 RESIDUES AND OXIDES $\ldots \ldots \ldots \ldots \ldots \ldots \ldots \ldots \ldots \ldots$

3.3.1 Scope $\ldots \ldots \ldots \ldots \ldots \ldots \ldots \ldots \ldots \ldots \ldots .13$

3.3.2 Remediation Objectives ............... 3-14

3.3.3 Remediation Processes . . . . . . . . . . . . . . 3-15

3.3.4 Schedule Objectives . . . . . . . . . . . . . . . 3-16

3.3 .5 Assumptions . . . . . . . . . . . . . . 3-17

3.3.6 Issues and Problems $\ldots \ldots \ldots \ldots \ldots \ldots \ldots$. . . . . . . . . . . . . . . . .

3.3.7 Alternatives/Impacts $\ldots \ldots \ldots \ldots \ldots \ldots \ldots \ldots$. . . . . . . . . .

3.3.8 Technology Development . . . . . . . . . . . . . 3-18

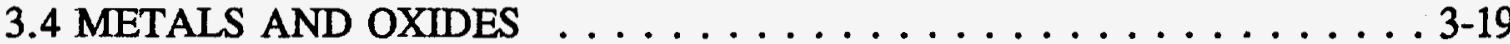

3.4 .1 Scope $\ldots \ldots \ldots \ldots \ldots \ldots \ldots \ldots \ldots \ldots \ldots \ldots . \ldots \ldots$

3.4.2 Remediation Objectives . . . . . . . . . . . . 3-19

3.4.3 Remediation Process . . . . . . . . . . . . . . . 3-19

3.4.4 Schedule Objectives . . . . . . . . . . . . . . . . 3-19

3.4 .5 Assumptions . . . . . . . . . . . . . . . 3-20

3.4.6 Issues and Problems . . . . . . . . . . . . . . 3-20

3.4.7 Alternatives/Impacts $\ldots \ldots \ldots \ldots \ldots \ldots \ldots \ldots \ldots$ 3-21

3.4.8 Technology Development . . . . . . . . . . . . . 3-21

3.5 ACTIVITIES COMMON TO ALL PLUTONIUM-BEARING

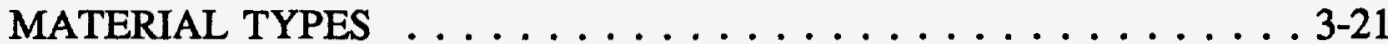

3.5 .1 Scope $\ldots \ldots \ldots \ldots \ldots \ldots \ldots \ldots \ldots \ldots \ldots \ldots \ldots \ldots \ldots \ldots .21$

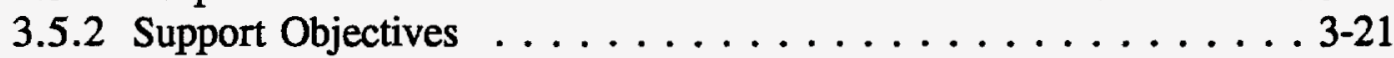

3.5.3 Support Systems Descriptions . . . . . . . . . . . . . . 3-22

3.5.4 Schedule Objectives . . . . . . . . . . . . . . . 3-22

3.5.5 Assumptions . . . . . . . . . . . . . . 3-23

3.5.6 Issues and Problems . . . . . . . . . . . . . 3-23

3.5.7 Alternatives/Impacts $\ldots \ldots \ldots \ldots \ldots \ldots \ldots \ldots$. . . . . . . . . . . . . .

3.5.8 Technology Development $\ldots \ldots \ldots \ldots \ldots \ldots \ldots$. . . . . . . . . . .

3.6 DOSE EVALUATION . . . . . . . . . . . . . . . . . . 3-24

3.7 CHARACTERIZATION OF PLUTONIUM-BEARING MATERIALS3-25 
3.8 PLUTONIUM FINISHING PLANT FINAL SAFETY ANALYSIS

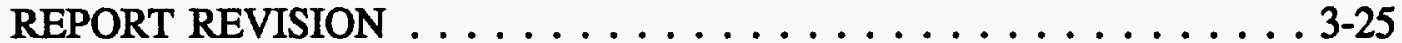

3.9 INTERNATIONAL ATOMIC ENERGY AGENCY INTERACTION . . . 3-25

3.10 WORK PLAN $\ldots \ldots \ldots \ldots \ldots \ldots \ldots \ldots \ldots \ldots \ldots \ldots \ldots \ldots \ldots \ldots .26$

3.11 PLUTONIUM VULNERABILITY CORRECTIVE ACTIONS $\ldots \ldots \ldots$ 3-26

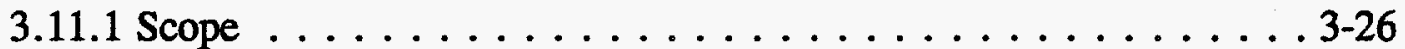

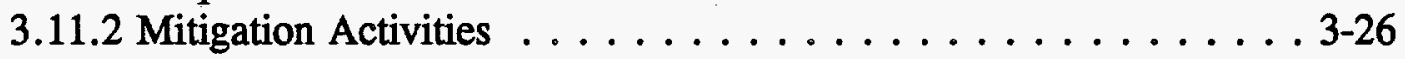

4.0 REFERENCES $\ldots \ldots \ldots \ldots \ldots \ldots \ldots \ldots \ldots \ldots \ldots \ldots \ldots \ldots . \ldots \ldots$. . . . . . . . . . .

\section{APPENDIX}

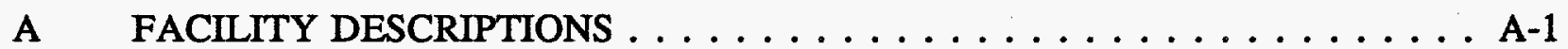

\section{LIST OF FIGURES}

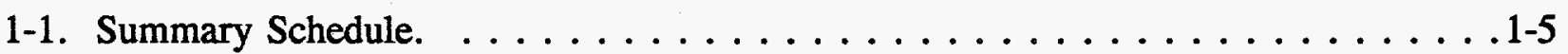

2-1. Location of Hanford Spent Nuclear Fuels. . . . . . . . . . . . . . . . . 2-2

2-2. Accelerated Fuel Removal Process. . . . . . . . . . . . . . . . . . . . 2-8

2-3. Hanford Site Spent Nuclear Fuel Flow Diagram. . . . . . . . . . . . . . 2-18

3-1. Material Flow for DNFSB 94-1 Baseline Plan. . . . . . . . . . . . . . . . 3-6

3-2. PFP Building Layout - Location of Process Areas. . . . . . . . . . . . . 3-7

\section{LIST OF TABLES}

1-1. Budget Profile . . . . . . . . . . . . . . . . . . . 1-7

2-1. Hanford Spent Nuclear Fuel Inventories. . . . . . . . . . . . . 2-3

2-2. Funding Requirements. . . . . . . . . . . . . . . . 2-26

3-1. Inventory of Plutonium-Bearing Materials $\ldots \ldots \ldots \ldots \ldots \ldots \ldots . \ldots \ldots$

3-2. Milestone Summary. . . . . . . . . . . . . . . . . . . . . 3-8

3-3. Hanford Plutonium ES\&H Vulnerabilities . . . . . . . . . . . . 3-28 


\section{LIST OF TERMS}

\begin{tabular}{|c|c|}
\hline BWR & Boiling Water Reactor \\
\hline $\mathrm{CCC}$ & Core Component Container \\
\hline CSB & Canister Storage Building \\
\hline DNFSB & Defense Nuclear Facilities Safety Board \\
\hline DOE & U.S. Department of Energy \\
\hline DOE-HQ & U.S. Department of Energy, Headquarters \\
\hline Ecology & Washington State Department of Ecology \\
\hline EIS & Environmental Impact Statement \\
\hline EPA & U.S. Environmental Protection Agency \\
\hline FFTF & Fast Flux Test Facility \\
\hline FSAR & Final Analysis Safety Report \\
\hline FY & Fiscal Year \\
\hline GPP & General Plant Project \\
\hline IAEA & International Atomic Energy Agency \\
\hline INEL & Idaho National Engineering Laboratory \\
\hline IP & Implementation Plan \\
\hline IPP & Integrated Program Plan \\
\hline ISA & Interim Storage Area \\
\hline ISC & Interim Storage Cask \\
\hline LAMPRE & Los Alamos Molten Plutonium Reactor Experiment \\
\hline LLBG & Low-Level Burial Ground \\
\hline LOI & Loss On Ignition \\
\hline LWR & Light Water Reactor \\
\hline MCO & Multi Canister Overpack \\
\hline MTU & Metric Tons Uranium \\
\hline NEPA & National Environmental Policy Act \\
\hline OSU & Oregon State University \\
\hline PFP & Plutonium Finishing Plant \\
\hline PNL & Pacific Northwest Laboratories \\
\hline PRF & Plutonium Reclamation Facility \\
\hline PUREX & Plutonium-Uranium Extraction \\
\hline PWR & Pressurized Water Reactor \\
\hline RCRA & Resource Conservation and Recovery Act \\
\hline RL & U.S. Department of Energy, Richland Operations Office \\
\hline ROD & Record of Decision \\
\hline RSB & Reactor Service Building \\
\hline SAS & Safeguards and Security \\
\hline
\end{tabular}


SISMP Site Integrated Stabilization Management Plan

SNF Spent Nuclear Fuel

SNFP Spent Nuclear Fuel Project

SPR Single Pass Reactor

TRIGA Training Reactor, Isotopes, General Atomics

TRU Transuranic

WHC Westinghouse Hanford Company

WT\% Weight Percent

WIPP Waste Isolation Pilot Plant 
WHC-EP-0853 REV. 1

This page intentionally left blank. 


\subsection{INTRODUCTION}

\subsection{BACKGROUND}

In May 1994, the Defense Nuclear Facilities Safety Board (DNFSB) issued DNFSB Recommendation 94-1 (Conway 1994), which identified concerns related to U.S. Department of Energy (DOE) management of legacy fissile materials remaining from past defense production activities. The DNFSB expressed concern about the existing storage conditions for these materials and the slow pace at which the conditions were being remediated. The DNFSB also expressed its belief that additional delays in stabilizing these fissile materials would be accompanied by further deterioration of safety and unnecessary increased risks to workers and the public.

In February 1995, DOE issued the DNFSB Recommendation 94-1 Implementation Plan (O'Leary 1995) to address the concerns identified in DNFSB Recommendation 94-1. The Implementation Plan (IP) identifies several DOE commitments to achieve safe interim storage for the legacy fissile materials, and constitutes DOE's baseline DNFSB Recommendation 94-1 Integrated Program Plan (IPP). The IPP describes the actions DOE plans to implement within the DOE complex to convert its excess fissile materials to forms or conditions suitable for safe interim storage. The IPP is being further developed to include complex-wide research and development and a long-range facility requirements section related to the IPP objectives. Consistent with DNFSB's recommendation, the IPP additions are being developed based on a systems engineering approach that integrates facilities and capabilities at the various DOE sites and focuses on attaining safe interim storage with minimum safety risks and environmental impacts.

Each affected DOE site has developed a Site Integrated Stabilization Management Plan (SISMP) to identify individual site plans to implement the DNFSB Recommendation 94-1 IPP and to provide a basis for formulating planned additions to the IPP. The SISMPs were developed based on the objectives, requirements, and commitments identified in the baseline DNFSB Recommendation 94-1 IPP.' The SISMPs will be periodically updated to reflect improved integration between DOE sites as identified during the IPP systems engineering evaluations.

The Hanford Site SISMP includes plans to address DNFSB Recommendation 94-1 concerns related to management of spent nuclear fuel and plutonium-bearing materials at the Hanford Site. The following Hanford Site-related concerns were identified in DNFSB Recommendation 94-1:

- $\quad$ "The $K$-East Basin at the Hanford Site contains hundreds of tons of deteriorating irradiated nuclear fuel from the $N$ Reactor. This fuel has been heavily corroded during its long period of storage under water, and the bottom of the basin is now covered by a thick deposit of sludge containing actinide compounds and fission products. The basin is near the Columbia River. It 
has leaked on several occasions, is likely to leak again, and has design and construction defects that make it seismically unsafe."

- "There are thousands of containers of plutonium-bearing liquids and solids at the Rocky Flats Plant, the Hanford Site, the Savannah River Site, and the Los Alamos National Laboratory. These materials were in the nuclear-weapons manufacturing pipeline when manufacturing ended. Large quantities of plutonium solutions are stored in deteriorating tanks, piping, and plastic bottles. Thousands of containers at the Rocky Flats Plant hold miscellaneous plutonium-bearing materials classed as "residuals", some of which are chemically unstable. Many of the containers of plutonium metal also contain plastic and, in some at the Rocky Flats Plant, the plastic is believed to be in intimate contact with the plutonium. It is well known that plutonium in contact with plastic can cause formation of hydrogen gas and pyrophoric plutonium compounds leading to a high probability of plutonium fires."

The plans in the Hanford Site SISMP have been developed consistent with the DNFSB recommendations, including the following recommendations directly affecting the Hanford Site:

"That the program be accelerated to place the deteriorating reactor fuel in the $K$-East Basin at the Hanford Site in a stable configuration for interim storage until an option for ultimate disposition is chosen. This program needs to be directed toward storage methods that will minimize further deterioration."

"That an integrated program plan be formulated on a high priority basis, to convert within 2-3 years the materials addressed in the specific recommendations below, to forms or conditions suitable for safe interim storage. This plan should recognize that remediation will require a systems engineering approach, involving integration of facilities and capabilities at a number of sites, and will require attention to limiting worker exposure and minimizing generation of additional waste and emission of effluents to the environment. The plan should include a provision that, within a reasonable period of time (such as eight years), all storage of plutonium metal and oxide should be in conformance with the draft DOE Standard on storage of plutonium now being made final."

Consistent with commitments in the DNFSB Recommendation 94-1 IP, schedule acceleration will result in removal of spent nuclear fuel (SNF) from the K-East Basin (105-KE Basin) by December 1999 and will result in placement of plutonium-bearing materials at the Hanford Site Plutonium Finishing Plant (PFP) into safe interim storage by May 2002. 


\subsection{PURPOSE}

This document comprises the Hanford SISMP. This document describes the DOE's plans at the Hanford Site to address concerns identified in DNFSB Recommendation 94-1. This document also identifies plans for other SNF inventories at the Hanford Site which are not within the scope of DNFSB Recommendation 94-1 for reference purposes because of their interrelationship with plans for SNF within the scope of DNFSB Recommendation 94-1. The SISMP is also used to assist DOE in formulating and maintaining planned additions to the IPP, including research and development requirements and a long-range facility requirements section (i.e., the DNFSB Recommendation 94-1 Research and Development Plan and Integrated Facilities Plan).

\subsection{SCOPE}

Materials within the scope of this SISMP include spent nuclear fuel (SNF) and plutonium-bearing materials currently located at the Hanford Site as identified in DOE's DNFSB Recommendation 94-1 IP. The Hanford SISMP is comprised of two volumes. Volume 1 provides the plans for placing the SNF and plutonium-bearing materials into safe interim storage, and Volume 2 provides integrated schedules for completion of the planned work scope identified in Volume 1.

\subsection{ORGANIZATIONAL RESPONSIBILITIES}

Multiple organizations will support implementation of planned activities identified in this SISMP. The U.S. Department of Energy-Headquarters (DOE-HQ) general organizational roles and responsibilities and interfaces with the DOE field offices for DNFSB 94-1-related activities are defined in the DNFSB 94-1 Implementation Plan (O'Leary 1995).

At the U.S. Department of Energy, Richland Operations Office (RL), the Spent Nuclear Fuel Project Division (SFD) has responsibility for the overall management, administration, and performance of the SNF Project to ensure the required levels of quality, safety, and environmental compliance are achieved within established technical, cost, and schedule baselines. The SFD is also responsible for management of the Hanford Site development of the SISMP and verifying performance to SNF related aspects of the SISMP schedule, cost, and technical baselines.

The Westinghouse Hanford Company (WHC) SNF Project is responsible for implementing the 105-K Basins path forward and integrating interim storage activities for other Hanford SNF inventories. The WHC SNF Project is also responsible for developing the Hanford Site SNF related input to the SISMP and providing contractor input on performance of SNF related schedule, cost, and technical baselines to the RL SFD. Specific responsibilities and authorities for management of Hanford Site SNF activities are identified in WHC-SD-SNFPMP-011, Hanford Site Spent Nuclear Fuel Project Management Plan (WHC 1995a). 
The RL Transition Project Division (TPD) has responsibility for management of the Plutonium Finishing Plant (PFP) that is similar to SFD's responsibilities for SNF management. The TPD's PFP Transition Project Office provides oversight on the performance of WHC with respect to schedules, costs, and technical baseline for the RL Transition Projects Division. The WHC PFP Transition Project provides the management and organization necessary for PFP to stabilize, store, and dispose of those materials covered by this SISMP until final disposition. The WHC PFP Transition Project ensures that PFP is managed in a safe, efficient, and environmentally sound manner to achieve the objectives of this SISMP. Responsibilities and standards of operation required in the performance of all work at PFP are identified in WHC-CM-5-8, Plutonium Finishing Plant Administration, Volume 1 .

The responsible RL and WHC Recommendation 94-1 Program Managers are as follows:

Spent Nuclear Fuel

RL

A. J. Colburn

509-376-6671

WHC

R. L. McCormack

509-376-7057

Plutonium Bearing Materials

$\begin{array}{lll}\text { RL } & \text { D. W. Templeton } & 509-373-2966 \\ \text { WHC } & \text { T. E. Huber } & 509-373-1503\end{array}$

\subsection{SUMMARY}

The plans identified in the Hanford Site SISMP will result in removal of SNF from the 105-K Basins by December 1999, consistent with the DNFSB's recommendation "That the program be accelerated to place the deteriorating reactor fuel in the $K-E$ ast Basin at the Hanford Site in a stable configuration for interim storage until an option for ultimate disposition is chosen." Additionally, plutonium bearing materials will be placed in safe interim storage by May 2002. A summary schedule for planned activities is provided in Figure 1-1.

The cost of achieving safe interim dry storage of the 105-K Basins SNF is estimated at $\$ 468$ million. This cost is based on current budget estimates and includes the costs to retrieve, transport, stage, condition and implement dry interim storage (i.e., characterize SNF, acquire facilities, etc.) and disposition 105-K Basins sludge. The projected cost to store the 105-K Basins SNF until dry interim storage is achieved is $\$ 623$ million. This cost includes operations at the 105-K Basins in addition to the costs to achieve safe interim dry storage. The $\$ 623$ million estimated cost does not include the program costs associated with $105-\mathrm{K}$ Basins deactivation. These costs are based on remaining costs for the activities from the beginning of FY 1996 until completion. 
Figure 1-1. Summary Schedule.

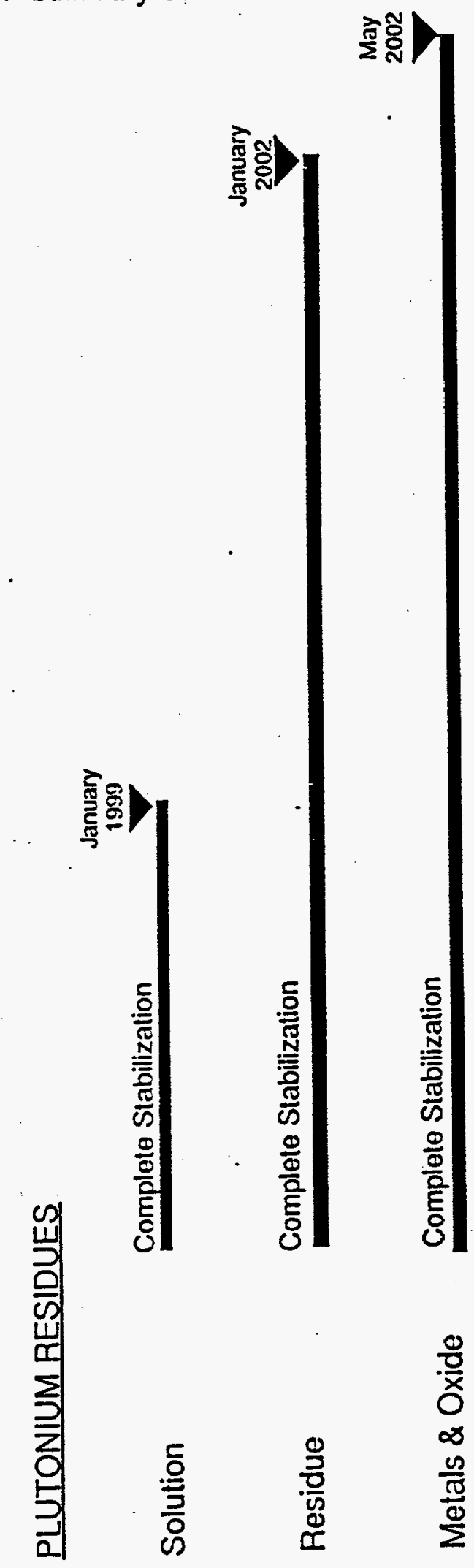


The cost to achieve safe interim storage of the plutonium-bearing materials is estimated at $\$ 145$ million to $\$ 160$ million. This plan assumes that DOE will reallocate resources to provide the budgets necessary to attain safe interim storage within schedule commitments. The budget profiles are summarized in Table 1-1. 
Table 1-1. Budget Profile (in millions of dollars).

\begin{tabular}{|l|c|c|c|c|c|c|c|}
\hline & FY 1996 & FY 1997 & FY 1998 & FY 1999 & FY 2000 & FY 2001 & FY 2002 \\
\hline 105-K Basins Total* & 134.7 & 174.7 & 122.7 & 100.4 & 79.0 & 11.0 & - \\
$\begin{array}{l}\text { - Actions to Achieve } \\
\text { Dry Interim Storage }\end{array}$ & 105.1 & 145.0 & 93.0 & 70.9 & 48.3 & 5.7 & - \\
$\begin{array}{l}\text { Other 105-K Basins } \\
\text { Project Activities }\end{array}$ & 29.6 & 29.7 & 29.7 & 29.5 & 30.7 & 5.3 & - \\
\hline $\begin{array}{l}\text { Plutonium-Bearing } \\
\text { Materials }\end{array}$ & 20.5 & 27.4 & 31.3 & 21.0 & 19.8 & 15.8 & 14.7 \\
\hline
\end{tabular}

* Actions to achieve dry interim storage of 105-K Basins SNF include fuel retrieval, transport, staging, conditioning, and emplacement into dry storage (i.e., characterization, facility acquisitions, etc.). Other 105-K Basins project activities include on-going 105-K Basins operations. Costs associated with other Hanford Site SNF management and 105-K Basins deactivation are not included in the 105-K Basins Total cost estimate. 
WHC-EP-0853 REV. 1

This page intentionally left blank. 


\subsection{HANFORD SITE SPENT NUCLEAR FUEL}

The Hanford Site's Spent Nuclear Fuel Project (SNF Project) was formed in early 1994 to manage the Hanford Site's SNF and to address the urgent need to move the SNF from its present degraded storage conditions at the 105-K Basins to safe interim storage until final disposition. Additionally, the SNF Project was chartered to integrate management of all SNF within the Hanford Site, to interface with DOE's Integrated Spent Fuel Program, and to integrate Hanford Site SNF management with DOE complex-wide SNF management.

Activities conducted to manage Hanford Site SNF inventories are focused on remedying the DNFSB Recommendation 94-1 concern at the 105-KE Basin. Consistent with SNF Project objectives and the DNFSB Recommendation 94-1 IPP systems engineering approach, plans to place other Hanford Site SNF into safe interim storage are being integrated with the 105-KE Basin plans and with Hanford Site activities that manage other legacy materials. Additionally, all Hanford Site SNF inventories are included within the scope of the DOE Integrated Spent Fuel Program, which is developing plans for integrated interim storage and technology development for all DOE-owned SNF.

Sections 2.1 and 2.2 of the Hanford Site SISMP identify DOE's plans for remedying near-term safety concerns and achieving safe interim storage of 105-K Basins SNF and other Hanford Site SNF, respectively. Issues and plans common to all Hanford Site SNF are addressed in Sections 2.3 through 2.5. Current Hanford Site SNF storage locations are shown in Figure 2-1. The SNF inventories at each facility, and current management concerns, are identified in Table 2-1.

More comprehensive descriptions of the fuel storage facilities and the fuel inventories are available in WHC-SD-SNF-TI-001, Hanford Spent Fuel Inventory Baseline (Bergsman 1994).

\subsection{5-K BASINS SPENT NUCLEAR FUEL}

\subsubsection{Scope}

The scope of this portion of the Hanford SISMP includes plans to remedy the urgent safety concerns at the 105-K Basins and place the 105-K Basins SNF into safe interim storage. The 105-KE and 105-KW Basins store approximately 2,100 metric tons of uranium (MTU) of defense (or "materials") production reactor SNF, primarily N Reactor SNF. This scope includes management of the PUREX Plant and N Basins SNF after transfer to the 105-K Basins. Transfer of the PUREX Plant and N Basins SNF inventories to the 105-K Basins is discussed in Section 2.2. 
Figure 2-1. Location of Hanford Spent Nuclear Fuels.

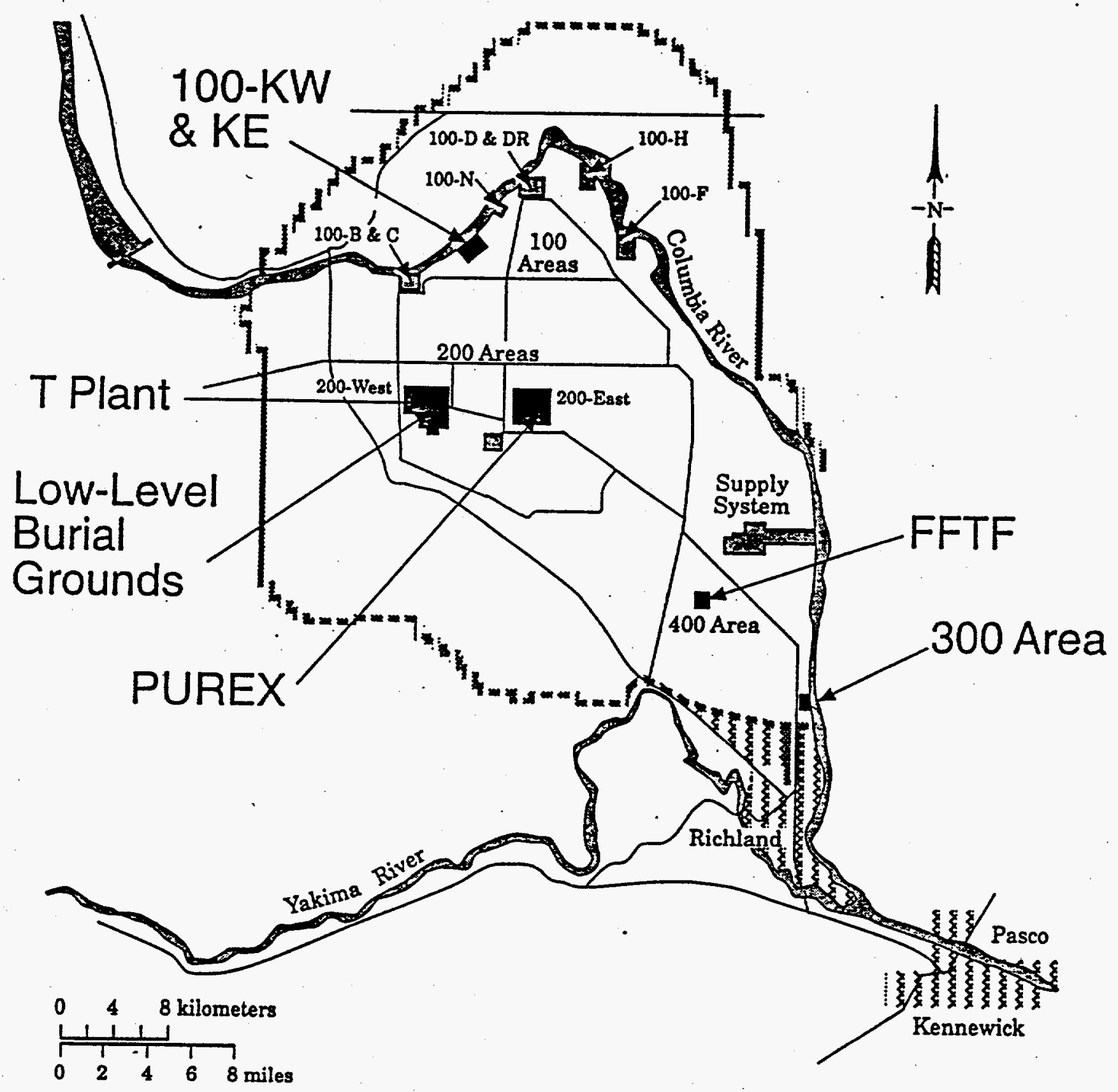


Table 2-1. Hanford Spent Nuclear Fuel Inventories.

\begin{tabular}{|c|c|c|c|}
\hline $\begin{array}{l}\text { Material } \\
\text { Group }\end{array}$ & Storage Location & $\begin{array}{l}\text { Quantity } \\
\text { (Metric Tons of } \\
\text { Heavy Metal) }\end{array}$ & Material/Packaging Concerns \\
\hline $\begin{array}{l}\text { Materials Production Fuels } \\
\text { - N Reactor } \\
\text { - Single-Pass Reactor }\end{array}$ & 105-KE Basin & $\begin{array}{r}1145.7 \\
0.4\end{array}$ & $\begin{array}{l}\text { Seriously deteriorated storage conditions; lack of } \\
\text { containment; corroding fuel; seismic vulnerability; aging } \\
\text { facility }\end{array}$ \\
\hline $\begin{array}{l}\text { Materials Production Fuels } \\
\text { - N Reactor } \\
\text { - Single-Pass Reactor }\end{array}$ & 105-KW Basin & $\begin{array}{r}954.1 \\
3.0\end{array}$ & Corroding fuel; seismic vulnerability; aging facility \\
\hline $\begin{array}{l}\text { Research Reactor Fuel } \\
\text { - Fast Flux Test Facility }\end{array}$ & $\begin{array}{l}\text { Fast Flux Test } \\
\text { Facility }\end{array}$ & 11.0 & $\begin{array}{l}\text { No significant material concern; facility deactivation requires } \\
\text { alternate storage }\end{array}$ \\
\hline Materials Production Fuels & PUREX Plant & N/A & Material transferred to $105-\mathrm{KW}$ Basin on $10 / 12 / 95$. \\
\hline $\begin{array}{l}\text { Special Case } \\
\text { - Shippingport }\end{array}$ & T Plant & 15.8 & $\begin{array}{l}\text { Aging facility; inefficient wet storage; facility mission } \\
\text { necessitates alternate storage }\end{array}$ \\
\hline $\begin{array}{l}\text { Miscellaneous Special Case and } \\
\text { Research Reactor Fuels }\end{array}$ & $\begin{array}{l}324,325,327 \\
\text { Buildings }\end{array}$ & 2.3 & $\begin{array}{l}\text { Dispersible material clean-up and facility vulnerability } \\
\text { corrective actions necessitate alternate fuel storage; safety } \\
\text { authorization not to current standards }\end{array}$ \\
\hline $\begin{array}{l}\text { Specialty Fuels } \\
\text { - TRIGA Fuel }\end{array}$ & 308 Building & 0.02 & Facility deactivation requires alternate storage \\
\hline $\begin{array}{l}\text { Specialty Fuels } \\
\text { - LAMPRE Fuel } \\
\text { - Univ. of Washington Fuel }\end{array}$ & $\begin{array}{l}\text { Plutonium Finishing } \\
\text { Plant }\end{array}$ & $\begin{array}{r}0.008 \\
8.4 \times 10^{-5}\end{array}$ & LAMPRE fuel packaging likely required for interim storage \\
\hline $\begin{array}{l}\text { Specialty Fuels } \\
\text { - TRIGA Fuel }\end{array}$ & $\begin{array}{l}\text { Low-Level Burial } \\
\text { Grounds }\end{array}$ & 0.02 & $\begin{array}{l}\text { Material buried with TRU waste in solid waste management } \\
\text { system. Retrieval in parallel with solid waste retrieval } \\
\text { planned to minimize personnel exposure/risks. }\end{array}$ \\
\hline TOTAL & Hanford Site & 2,132 & \\
\hline
\end{tabular}




\subsubsection{Remediation Objective}

The objectives of the plans in this SISMP, in regard to management of 105-K Basins SNF inventories, are:

1) Resolve the safety and environmental concerns associated with the deteriorating SNF in the 105-K Basins, including those identified in DNFSB Recommendation 94-1 and in the November 1993 document, DOE Spent Fuel Working Group Report on Inventory and Storage of the Department's Spent Nuclear Fuel and other Reactor Irradiated Nuclear Materials and the Environmental, Safety, and Health Vulnerabilities (DOE 1993); and

2) Attain safe, environmentally sound, and economic dry interim storage of the 105-K Basins SNF.

Safe dry interim storage for the 105-K Basins SNF will be attained when the SNF is stored in a manner that satisfies dry interim storage requirements for DOE-owned SNF as defined in the Office of Spent Fuel Management's Functions and Requirements Document

(DOE 1994b) and that achieves nuclear safety equivalent to comparable Nuclear Regulatory Commission (NRC) licensed facilities.

\subsubsection{Remediation Process}

Fuel removal from the 105-K Basins and implementation of safe dry interim storage will be achieved consistent with the general approach identified in the October 1994 WHC report, WHC-EP-0830 (Fulton 1994), as refined by the integrated process strategy for K Basins SNF approved by RL in July 1995 (DOE 1995a). Sludge will be dispositioned consistent with the RL approved K Basins sludge disposition strategy (DOE 1995b), contingent on regulatory approval. Near-term safety and environmental concerns at the 105-K Basins will be addressed in parallel with long-term actions to achieve dry interim storage.

The primary steps of the remediation process are as follows:

- The 105-K Basins SNF will be desludged and placed in racks within MultiCanister Overpacks (MCO's), vacuum dried at low temperature to remove free water. The "cold vacuum dried" SNF will be shipped to 200 East Area for storage in the MCO's at the Canister Storage Building (CSB), which was originally designed and construction initiated for storage of vitrified high-level waste from the Hanford Waste Vitrification Plant. The SNF will also be vacuum dried at a higher temperature to remove bound water and reactive sites on the surface of the SNF will be oxidized, as necessary, to reduce reactivity. The initial "cold vacuum drying" step will satisfy requirements for SNF removal from the 105-K Basins, consistent with the December 1999 commitment. The subsequent "hot vacuum conditioning" step will further improve the safety posture and economics of storage at the CSB for the interim 
storage period. The location and timing of the "hot vacuum conditioning" step is currently being defined, with the goal that "hot vacuum conditioning" be performed as early as practical to minimize SNF handling requirements.

- The 105-K Basins sludge will be retrieved, characterized, and transferred to the 200 Area tank farms for disposition with tank farm waste, contingent on characterization results. The sludge will be managed as SNF until the determination is completed that the sludge satisfies tank waste acceptance criteria.

Storage at the CSB will be in a manner that results in nuclear safety equivalent to comparable NRC licensed SNF storage facilities.

The actions are contingent on the outcome of on-going National Environmental Policy Act (NEPA) review and will be revised, if necessary, to ensure consistency with decisions arrived at in the NEPA review process.

\subsubsection{Preparation}

During the preparation period for fuel removal, near-term actions are being completed to improve the safety and environmental protection posture of the 105-K Basins in parallel with actions to remove the SNF and achieve safe dry interim storage. The following activities have been completed since issuance of DNFSB Recommendation 94-1 or will be completed in the near-term to improve the safety and environmental protection posture at the $105-\mathrm{K}$ Basins:

- Installation of seismic isolation barriers (e.g., cofferdams) between the 105-KE Basin and the discharge chute to isolate the basin from the suspected leak site located in the unreinforced construction joint in the discharge chute. This action minimizes the potential for environmental release of contaminated sludge either directly through the leak into the ground or by airborne release, should the basin be drained as a consequence of a seismic event and the sludge dry to a powder. This action also addresses concerns about fuel dryout and possible pyrophoric ignition leading to radioactive material releases. Maintaining the fuel under water prohibits pyrophoric ignitions. Similarly, installation of seismic isolation barriers at the 105-KW Basin reduces environmental and safety risks, although the consequences of leakage should be less than at the 105-KE Basin due to fuel and sludge containment and water quality at the 105-KW Basin.

- Development and implementation of the path forward for sludge removal from the 105-K Basins. The sludge contained in the fuel canisters is primarily the result of fuel corrosion, while the vast majority of the sludge on the basin floors is believed to consist of blow sand, structural material oxides, and 
concrete spallation products. The path forward will address removal of the entire sludge inventory based on material characteristics.

- Establishment and maintenance of a formal Conduct of Operations program at the 105-K Basins to improve safety of ongoing operations.

- Completion of essential facility systems recovery actions necessary for continued safe operations and personnel protection, such as electrical, potable water, fire protection, and maintenance systems.

- Reduction of personnel exposure in keeping with as-low-as-reasonablyachievable (ALARA) practices by improving dose reduction measures and reducing the radioactive source term from cesium-contaminated concrete basin walls and pipe runs.

- Removal of debris from the $\mathrm{K}$ East Basin such as unused canisters and discarded tools. This waste will be cleaned and compacted prior to shipment to the solid waste management area to minimize the waste volume.

- Improvement of water cleanup, including minimizing transuranic (TRU) loading of the ion exchange modules and providing redundant systems to ensure that adequate ion exchange capability is always available.

For SNF removal, the following activities will be completed at the 105-K Basins:

- Acquisition of systems required for SNF removal, including SNF retrieval, desludging, and "cold vacuum drying" systems.

- Characterization of SNF to support both SNF and sludge removal. The characterization will provide data that supports assessment of fuel condition, the degree of hydriding, and the makeup of the sludge. The data will also be used to support safety analyses for transport of the fuel and development of fuel conditioning.

- Operational readiness preparations for SNF removal activities at the 105-K

Basins. Because some SNF removal activities are similar to other recent activities (i.e., installation of the barrier doors, gas/liquid sampling, SNF characterization shipments, etc.), the readiness review process will be streamlined to minimize duplication of previous reviews. The readiness review process is being formulated to satisfy the intent of DOE Order 5480.31 and enable completion of the review process within schedule constraints. The readiness process will maximize the use of acceptance testing and operational testing. The testing will include a demonstration of the activity using dummy fuel elements once the equipment is installed in the basin. The demonstration will be conducted in the $105-\mathrm{KW}$ Basin so as to minimize the dose and allow 
for minimum decontamination of the equipment, if removal is required. Readiness preparations will address staffing and training requirements.

Major acquisitions will be completed to support the 105-K Basins path forward, including: the CSB; the fuel transportation system; the MCO's; and the "hot vacuum conditioning" system. Projects have been initiated for each of these subprojects. Consistent with the IPP, the start-up of the systems will satisfy the intent of DOE Order 5480.31. The draft plan for start-up of the CSB is identified in Brown (1995). An integrated startup operations group is being organized to conduct readiness activities for the CSB in conjunction with other path forward activities. The group is currently formulating appropriate readiness activities.

To ensure that these systems/facilities are acquired and operations completed within technical and schedule commitments identified in the IPP, DOE will take the following actions:

- Establish a dedicated DOE project office for executing the 105-K Basins SNF path forward and maximizing delegation of authority to the project office;

- Expedite project authorizations, including consolidation of key decisions;

- Establish a focused regulatory team and independent review team to streamline the process for establishing a safety authorization basis for the new storage system and achieving safety equivalence to comparable NRC-licensed facilities. The safety equivalence will be accomplished by applying technical requirements based on those applied by the NRC to comparable licensed facilities and by adopting appropriate features of the NRC licensing process, in addition to applicable DOE Orders and requirements.

- Expedite document preparation and DOE reviews required to complete the NEPA review process.

The NEPA review requirements for SNF removal from the 105-K Basins and actions to achieve dry interim storage will be addressed by the Environmental Impact Statement for Management of SNF from the K Basins at the Hanford Site, Richland, Washington (K Basins EIS). Including both steps in the $\mathrm{K}$ Basins EIS will enable acceleration of the second step that would not be possible with the two step NEPA review process identified in WHC-EP0830.

\subsubsection{Production}

Fuel removal will be initiated in December 1997 and completed in December 1999. The production phase will include operational activities to retrieve, dry, and transport the SNF and emplace the SNF in dry storage. Sludge removal will be completed by December 2000. "Hot vacuum conditioning" will be completed as soon as practical after December 1999. 


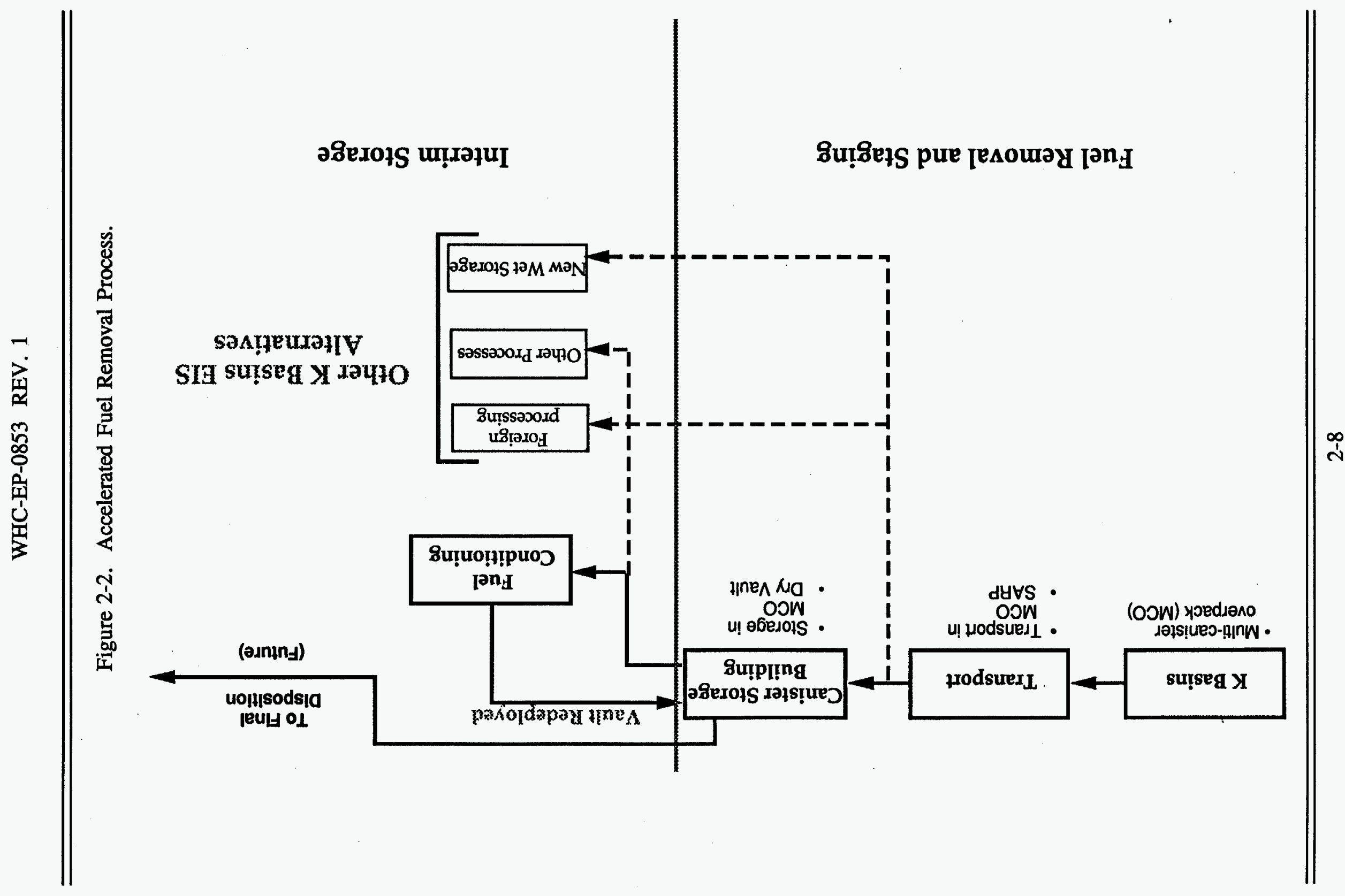




\subsubsection{Schedule Objectives}

The schedule objective for relocating 105-K Basins SNF to safe, compliant storage is December 1999 or earlier. In addition to this primary schedule objective, other schedule commitments will be or have already been fulfilled in accordance with the IPP.

The following IPP schedule commitments have been satisfied since issuance of DNFSB Recommendation 94-1:

- Develop potential funding options and an acquisition strategy as appropriate by the end of March 1995.

- Issue Notice of Intent for K Basins EIS in March 1995.

- Complete cofferdam installation in K West Basin by February 1995 and in K East Basin by April 1995.

- Start fuel characterization in hot cells by April 1995.

- Initiate sludge retrieval demonstration in conjunction with cofferdam installation by April 1995.

- Issue a K Basins integrated schedule by May 1995 that includes the following:

- $\quad$ Complete NEPA process;

- $\quad$ Submit project validation package;

- $\quad$ Initiate development for $\mathbf{N}$ Reactor fuel conditioning process;

- $\quad$ Finalize site identification and initiate site characterization for facilities;

- $\quad$ Place contract(s) for necessary equipment and facilities;

- $\quad$ Begin fuel removal from K Basins;

- Design MCO's;

- $\quad$ Begin MCO manufacture;

- $\quad$ Start and complete construction of CSB;

- $\quad$ Start and complete construction of conditioning facility;

- $\quad$ Start and complete fuel conditioning;

- $\quad \mathrm{K}$ Basin fuel in dry storage.

Additional schedule commitments identified in the IPP that have not yet been completed are as follows:

- Issue K Basins EIS Record of Decision by December 1995.

- Initiate removal of SNF from the K Basins by December 1997. 
In addition to the IPP commitments, agreements entered into by DOE with stakeholders will also be satisfied. Notably, enforceable milestone M-34-02 of the Hanford Federal Facility Compliance Order and Consent Agreement (Tri-Party Agreement) (Ecology 1994) will be satisfied. The Tri-Party Agreement is comprised of agreements made between DOE, the State of Washington Department of Ecology (Ecology) and the U.S. Environmental Protection Agency (EPA) with considerable public involvement. Milestone M-34-02 commits to the following:

- Initiate negotiations with Ecology and EPA on incorporation of transition activities, including stabilization of the basins, consistent with Section 3.1 of the Tri-Party Agreement and the Record of Decision regarding long-term storage and ultimate disposition of the irradiated fuel. DOE will submit a signed Tri-Party Agreement change request proposing milestones for: (1) removal of fuel and sludges from the K-Basins, and (2) stabilization of the basins by June 1996.

Additional schedules are identified in the October 1994 document, Plan of Action to Resolve Spent Nuclear Fuel Vulnerabilities (Phase III) (DOE 1994a).

The schedule provided in Volume 2 is an update of the integrated schedule that was completed before May 1995 and identifies the completion dates for all items identified in the seventh bullet, except where items were completed prior to issuance of the schedule. The schedule provides for completing activities to attain dry interim storage by June 2000 .

\subsubsection{Assumptions}

The scope, schedule, and costs identified in the Hanford Site SISMP for 105-K Basins SNF plans are based on several key assumptions:

- The technical scope and approach to implement the path forward for fuel removal from the 105-K Basins will be consistent with the general technical approach in the Westinghouse Hanford Company (WHC) report WHC-EP-0830, with the exception that both steps of the path forward will be completed under a single NEPA review.

- The K Basins EIS Record of Decision will be consistent with the plans identified in this SISMP.

- The CSB will be used for staging and storage of the 105-K Basins SNF.

- Budget and manpower resources will be available in support of critical path activities.

- Current onsite transportation requirements identified in U.S. DOE RL 5480.3 will not change. 
- Resource Conservation and Recovery Act (RCRA) permitting and Nuclear Regulatory Commission (NRC) licensing (or NRC review) will not be required for new storage or conditioning systems required to implement the 105-K Basins path forward.

- Current safeguards and security requirements identified in DOE Order 5333.2 will not change.

\subsubsection{Issues and Problems}

Critical issues that must be resolved to identify or implement actions at the Hanford Site and items that could limit schedule performance for 105-K Basins SNF include:

- RCRA applicability to 105-K Basins SNF and sludge must be finalized. The 105-K Basins path forward assumes that RCRA is not applicable to the fuel and sludge associated with the fuel. Schedule impacts would occur if the planning basis is not correct.

- The detailed regulatory criteria for attaining safe, compliant dry interim storage must be finalized. A regulatory review team and an independent review process have been established to support finalization of detailed regulatory criteria.

- The K Basins EIS schedule requires issuance of the Record of Decision in a nine month period after publishing the notice of intent. A stream-lined review process and delegation of authority to the Hanford Site manager for the EIS is needed to support the aggressive schedule. Any schedule delays from the EIS preparation and/or review process could delay the removal of SNF from the 105-K Basins.

- Hanford Site SNF must be characterized and process development supported sufficiently to evaluate and implement management options.

- Onsite transportation requirements must be maintained to enable onsite transport of SNF within schedule objectives.

- Adequate funding levels and funding stability for SNF management must be established.

\subsubsection{Alternatives}

A formal systems engineering process is being used to establish and maintain a technical baseline for SNF management. The functions and requirements developed by the Hanford Site systems engineering process are based on site-specific requirements and high-level SNF management requirements established by the DOE Office of Spent Fuel Management. The 
Hanford SNF Project technical baseline and functions and requirements are identified in WHC 1995c.

The systems engineering process resulted in identification of the following alternatives for the 105-K Basins fuel removal path forward:

Alternative 1: Alternative 1 overpacks the fuel stored in the 105-KE Basin and maintains storage of overpacked fuel at 105-KE Basin and encapsulated fuel at 105-KW Basin until a fuel conditioning and interim storage system is available. For comparison purposes, the fuel conditioning process is assumed to be based on repackaging and passivation of the fuel once it is received in the Fuel Conditioning Facility. The repackaged/passivated fuel is then transferred to an interim storage facility that is assumed to be based on a vault storage concept. This alternative also includes upgrading the existing 105-K Basins (retrofit and life extension).

Alternative 2: Alternative 2 overpacks the fuel stored in both 105-K Basins and transfers the overpacked fuel to a wet pre-interim (an existing facility modified for wet storage), or to a new wet storage facility. The fuel is stored in this wet storage facility until a conditioning and interim storage system is available. For comparison purposes, the fuel conditioning process is assumed to be based on a fuel passivation concept proposed by a DOE independent technical assessment team. The process transfers the fuel from the overpacks selected for the pre-interim wet storage to the package configuration developed for the passivation system, within the pre-interim wet storage facility. The repackaged fuel is then transferred to the Fuel Conditioning Facility for passivation. The passivated fuel is then transferred to the dry interim storage facility that is based on a vault storage concept. In this alternative, the principal driver is the prompt removal of the SNF from the 105-K Basins to another location for some period of pre-interim wet storage.

Alternative 3: Alternative 3 uses the passivation process identified in Alternative 2, without pre-interim wet storage. This alternative offers a possible method of early SNF conditioning with a potential for early achievement of interim dry storage. The SNF processing may be performed within a new addition to the $105-\mathrm{K}$ Basins or at a location associated with the dry interim storage facility.

Alternative 4: In this alternative, custody of the packaged SNF is transferred to a foreign enterprise that assumes responsibility for transoceanic transport and for processing to stable residues (conditioned wastes). In the preferred configuration, the residues are returned to the Hanford Site for interim dry storage to await final disposition. Alternative 4 includes packaging $\mathbf{N}$ Reactor SNF, assumes shipping the fuel to the British Nuclear Fuel Laboratories' Sellafield Plant located in the United Kingdom, and assumes processing the fuel at the Sellafield Plant and return of the residues to the Hanford Site for interim dry storage. The low- and intermediate-level wastes would be retained in the United Kingdom. Primary options within this alternative include: (1) shipping of unencapsulated damaged fuel in a British Nuclear 
Fuel Laboratories' cask instead of containerization of damaged fuel prior to cask loading; and (2) retention of conditioned waste/residue in the United Kingdom instead of returning it to the Hanford Site for interim dry storage.

The 105-K Basins path forward alternatives were evaluated using a multi-attribute decision process as described in the Westinghouse Hanford Company report WHC-EP-0830 (Fulton 1994). The evaluation process included scoping analyses of cost, schedule, safety and regulatory drivers; normalization of key assumptions and the bases for comparison; independent assessments by outside experts; and the use of decision analysis techniques to assure a comprehensive, balanced treatment of the pros, cons and uncertainties associated with the various alternatives. An important aspect of this process was the identification of vulnerabilities, their potential impacts and how they might be mitigated. For example, the impacts on related issues such as disposal of the water and debris, worker exposure, minimizing the cost and risks of continued operations in the 105-K Basins, etc., were considered in selecting the recommended path forward.

The evaluation process resulted in selection of the path forward identified in the Hanford Site SISMP, which combines the best attributes of the various alternatives to accelerate fuel removal from the 105-K Basins. DOE formal approval of the path forward is documented in Lytle (1994). Subsequent assessments have resulted in refinements to plans defined in the path forward, as reflected in the work scope, costs and schedules identified in the SISMP. Notably, the integrated process strategy (WHC 1995b) was developed to define an integrated approach for fuel removal, transport, staging, conditioning, and dry storage of the 105-K Basins SNF.

Alternatives considered in the 105-K Basins path forward decision process will not enable fuel removal from the 105-KE Basin within 2-3 years, but will satisfy schedule commitments identified in the IP. Actions to improve the safety posture at the basin, such as installation of seismic isolation barriers, will reduce the risk of continued storage beyond three years.

\subsubsection{Technology Development}

Preliminary technology development needs for the 105-K Basins SNF are identified in the Hanford Spent Nuclear Fuel Project Technology Acquisition Plan (WHC DRAFT). To the extent practical, technology will be acquired through the use of commercially available technologies, including technologies from foreign and domestic sources.

The focus of the technology development activity will be developing fuel handling and conditioning process(es) for dry storage of defense production reactor SNF, because of the system specific activities required to place this SNF in a stable form for interim storage. Detailed technology development needs are being further refined and verified through the 
systems engineering process and incorporated into revisions of the Technology Acquisition Plan. Identified technology activities include the following:

- Hydride phenomena and ignition theory application- Chemical reactivity, including ignition theory will be modeled for accident analyses associated with fuel handling and conditioning processes to support a systems engineering approach directed toward storage methods. Fuel pyrophoricity concerns will be addressed to assist in establishing optimum safety authorization bases for activities to achieve dry storage of the 105-K Basins SNF.

- Chemical corrosion and hydrogen generation- Evaluations will be completed to understand the effects of chemical corrosion and hydrogen generation on achieving and maintaining safe dry interim storage. The evaluations will be used as a basis for refining the conditioning process, will systematically evaluate potential sludge and fuel particle corrosion or other reactions in waste tanks, and will assist in establishing safety authorization bases for SNF and sludge management.

- Vacuum drying and conditioning process modeling and demonstration- Process phenomena that define water removal, process time, ignition accidents of uranium metal, and long-term stability of the 105-K Basins SNF will be analyzed and tested. Thermal-hydraulic modelling results will support the definition of acceptable product criteria and processing limits.

Activities will utilize technical analysis and experience to the extent practical. Fuel characterization and process development will be used to provide information that cannot otherwise be obtained. Technology development activities will be integrated with development activities at other DOE complexes through the DOE Integrated Spent Fuel Program's Technology Integration Plan (DOE 1994b).

The cost of technology development for the 105-K Basins SNF is approximately $\$ 2.9 \mathrm{M}$, and is included within Table 2-2. If technology development is unsuccessful, more conservative designs would be required, and could potentially increase project costs. 


\subsection{OTHER HANFORD SITE SPENT NUCLEAR FUEL}

\subsubsection{Scope}

Plans to attain safe interim storage for Hanford Site SNF that is currently located at facilities other than the 105-K Basins (i.e., "other SNF") are included in the SISMP for information, due to the potential for utilizing common facilities with DNFSB Recommendation 94-1 materials at the Hanford Site and other DOE sites. The facilities where the other SNF inventories are currently located and the respective facility missions are as follows:

- The T Plant, which serves as a beta-gamma decontamination facility and provides other solid waste management services in addition to storage of Shippingport Pressurized Water Reactor (PWR) Core 2 fuel.

- The Fast Flux Test Facility (FFTF), which provided testing capability for the U.S. fast breeder reactor program, notably irradiation and evaluation of different types of fuel assemblies and materials for fuel assembly construction. The FFTF also produced materials such as medical isotopes. The FFTF test mission recently ended and the facility is currently developing deactivation plans.

- The 308 Building, in the 300 Area of the Hanford Site, which was used for the manufacture and assembly of FFTF fuel and test assemblies. The building contains a small reactor known as the Neutron Radiography Facility. The reactor (a Mark I Training Reactor, Isotopics, General Atomics [TRIGA]) was operated intermittently from the late 1970 s until May 1989 and was used as the neutron source for radiographic non-destructive testing of FFTF fuel. The 308 Building is now being deactivated.

- The 325 Building Shielded Analytical Laboratory (and 325-A Radiochemical Facility), which support process demonstration and analytical chemistry requirements for a variety of DOE programs.

- The 324 Building, which is a shielded chemical processing laboratory used for development of chemical processes from laboratory to pilot scale and for examination and mechanical testing of irradiated specimens. The 324 Building contains laboratory, support facilities, and office space.

- The 327 Building, also known as the Post-irradiation Testing Laboratory (PITL), which provides shielded, ventilated, and specially equipped laboratories for physical and metallurgical examination and testing of irradiated fuels, concentrated fission products, and structural materials. The long-term mission of the facility is not certain. Near-term activities at the 327 Building include SNF characterization. 
- The Plutonium Finishing Plant in the 200 West Area, which supported plutonium metal production for the defense program. PFP is described in Section 3.0. SNF at PFP is currently stored at the $2736-Z B$ storage vault and in a storage module in the yard area.

- The 200 Area Low-Level Burial Ground (LLBG), which supports management of solid waste materials at the Hanford Site. The SNF at the LLBG is being managed consistent with requirements for remote-handled transuranic waste per DOE Order 5820.2A.

Legacy defense production reactor SNF (i.e., N Reactor and Single-Pass Reactor SNF) was previously stored at the Plutonium-Uranium Extraction (PUREX) Plant. The PUREX Plant SNF inventory was shipped to the 105-KW Basin in October 1995 and will be managed consistent with the other 105-K Basins SNF inventory.

Additionally, up to 0.5 metric tons heavy metal of N Reactor SNF may be remaining in the sludge at the floor of the $\mathrm{N}$ Basins. SNF recovered during $\mathrm{N}$ Basins deactivation will be transferred to the 105-KW Basin for consolidated management with other N Reactor SNF.

The inventories and storage concerns associated with the other Hanford Site SNF inventories were identified previously in Table 2-1. A brief description of the facilities is provided in Appendix A.

\subsubsection{Remediation Objective}

The objectives of the plans in this SISMP for other Hanford Site SNF inventories are to:

1) Complete interim actions to remove fuel from existing facilities to support current facility missions and corrective actions to vulnerabilities identified in the November 1993 document, DOE Spent Fuel Working Group Report on Inventory and Storage of the Department's Spent Nuclear Fuel and other Reactor Irradiated Nuclear Materials and the Environmental, Safety, and Health Vulnerabilities (DOE 1993); and

2) Attain safe, environmentally sound, and economic interim storage of all Hanford Site SNF pending establishment of a national SNF strategy and criteria for final disposition of DOE-owned SNF.

Interim actions will be performed and vulnerability corrective actions completed as identified in the October 1994 DOE document, Plan of Action to Resolve Spent Nuclear Fuel Vulnerabilities (Phase III) (DOE 1994a). Safe interim storage for the other Hanford Site SNF inventories will be attained when these materials are stored in a manner that satisfies dry interim storage requirements for DOE-owned SNF as defined in the Office of Spent Fuel Management's Functions and Requirements Document (DOE 1994b). 


\subsubsection{Remediation Process}

The near-term management and interim storage activities will be integrated to minimize SNF handling and resultant exposure and waste generation. Actions to attain safe interim storage of other Hanford SNF inventories will be performed as described in the following sections (see Figure 2-3).

These actions include near-term consolidation of most SNF currently in the 300 and 400 Areas at the 400 Area Interim Storage Area (ISA) outside of FFTF to support deactivation missions and vulnerability corrective actions at the FFTF, 308 Building, and 324/325/327 Buildings.

After construction of the CSB, a 200 Area ISA will be installed adjacent to the CSB. The SNF at the 400 Area ISA and most 200 West Area SNF will be transferred to the 200 Area ISA to minimize storage costs and enable deactivation of 400 Area facilities. The CSB will be used to transload SNF for transfer off-site, as final disposition is implemented.

Consistent with the DOE Integrated Spent Fuel Program's draft Interim Storage Plan, the planning basis assumed in the SISMP is as follows: Hanford defense production reactor SNF will remain at the Hanford Site; FFTF sodium-bonded SNF will be transferred to Argonne National Laboratory-West (ANL-W) in 1997 or 1998; other FFTF SNF will be transferred to INEL between 2008 and 2011; and other Hanford Site SNF will be transferred to INEL between 2000 and 2010, and likely after 2005. Based on a recent Consent Order from the United States District Court for the District of Idaho, the planning basis draft Interim Storage Plan will be modified in the near future (Idaho 1995). The Hanford SISMP will be revised to reflect the new planning basis at that time. It is anticipated that the new planning basis will delay shipment of the sodium-bonded FFTF SNF to ANL-W until after December 2000 and delay shipment of other non-defense production reactor SNF off-site until implementation of final disposition.

\subsubsection{FFTF SNF}

The FFTF SNF inventory will be removed from in-sodium storage at the FFTF to enable facility deactivation. The SNF will be transferred from FFTF to one of three near-term locations dependent on the SNF characteristics.

Sodium bonded FFTF SNF will be shipped to ANL-W in T-3 Casks for consolidation with similar SNF. The DOE Certificate of Compliance (CoC) for the T-3 Cask is being amended to accommodate full assemblies or an increased number of pins to curtail the number of shipments to ANL-W. The total number of shipments will be eight, consisting of six assemblies and two pin containers.

The remaining FFTF SNF will be washed in the FFTF Interim Examination and Maintenance (IEM) Cell to remove sodium. The assemblies will then be placed in unshielded Core Component Containers (CCC's) made from stainless steel and Inconel ${ }^{\oplus}$. A 


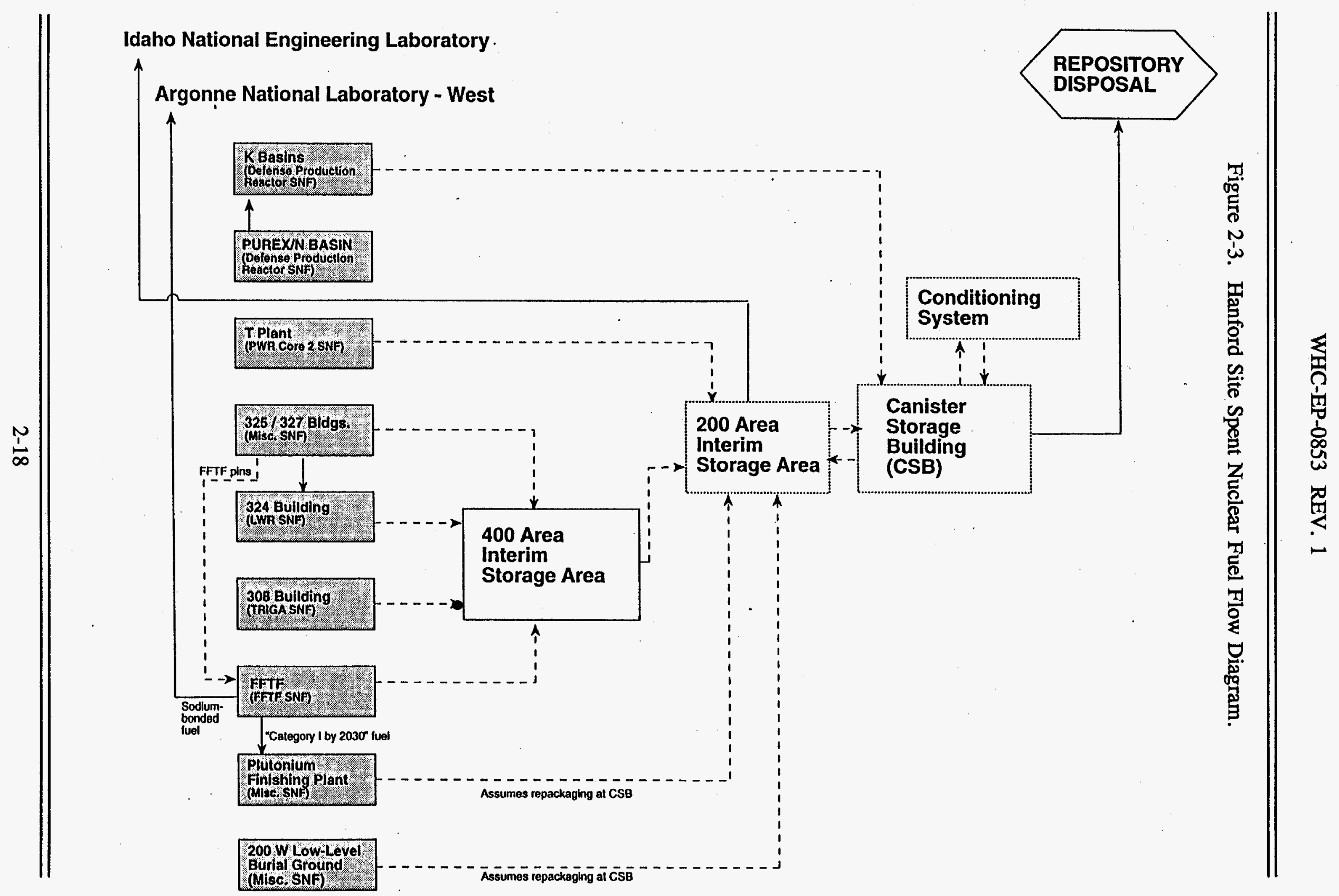


bottom loading shielded fixture called the Solid Waste Cask will be used to remove each CCC from the IEM Cell and take the CCC to the adjacent Reactor Service Building (RSB), where each CCC will be inserted into an FFTF Interim Storage Cask (ISC) that has been previously loaded into the Cask Loading Station.

A CCC is designed to hold six assemblies or pin containers. By removing the stainless steel end portion of an assembly, a seventh assembly will be added to each $\mathrm{CCC}$, provided that the decay heat of the SNF placed in the CCC does not exceed 1,500 watts. Only six pin containers may be placed in a CCC. Approximately 50 ISC's will be required by implementing this approach.

An ISC consists of a steel inner container bonded to concrete shielding using weld studs. The ISC's will function as secondary confinement. After each ISC is closed, the ISC will be inerted and moved to the adjacent 400 Area ISA, except for two ISC's that will be placed inside the protected area at PFP to satisfy safeguards requirements. The 400 Area ISA pad is surrounded by a locked fence and lighting fixtures.

The initial ISC was delivered to the 400 Area ISA in June 1995 and loading of this prototype cask is scheduled for late 1995. The last ISC is scheduled to be placed on the 400 Area ISA pad in late 1998. The ISCs will subsequently be transferred to the 200 Area ISA for storage until transfer off-site.

Assuming the FFTF SNF is shipped offsite, the 100 ton bridge crane, Solid Waste Cask, and Cask Loading Station will be removed from the FFTF RSB and installed in the CSB. An offsite transportation cask will be acquired for the CCC. Once this cask receives a DOE CoC and is fabricated, the CCC's will be removed from the ISC's, placed inside the transportation cask and shipped to INEL. The empty ISC's will be shipped to INEL and subsequently reloaded with the CCC's.

\subsubsection{308 Building Annex SNF}

Six NRF TRIGA ${ }^{\oplus a s k s ~ a r e ~ c u r r e n t l y ~ b e i n g ~ f a b r i c a t e d ~ f o r ~ b o t h ~ t r a n s f e r ~ a n d ~ s t o r a g e ~ o f ~ t h e ~}$

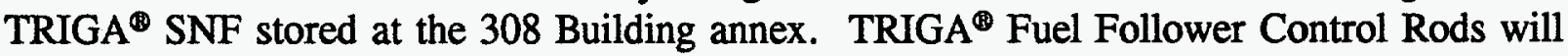
be shipped and stored in two DOT $6 \mathrm{M}$ containers that are currently being procured. The NRF TRIGA Casks and DOT 6M containers will be stored in a vault module at the 400 Area ISA.

All shipments from the 308 Annex to the vault at FFTF are scheduled to be complete by January 1996. The NRF TRIGA Casks were designed with the intention of securing a DOE $\mathrm{CoC}$ to enable shipment of the casks to INEL without repackaging. The DOT 6M casks are specification packages, and can be used for offsite shipment. The concrete vault will provide enhanced shielding during storage to meet the 400 Area ISA fence line maximum dose rate requirement of $0.5 \mathrm{mrem} / \mathrm{hr}$. 
Current plans are to transfer the NRF TRIGA casks, DOT $6 \mathrm{M}$ containers and vault to the 200 Area ISA consistent with the FFTF SNF.

\subsubsection{324/325/327 Building SNF}

The two BWR assemblies and five PWR assemblies and miscellaneous pins and pieces stored primarily in the 324 Radiochemical Engineering (RE) Cells will be encapsulated and transferred to dry storage casks. Encapsulation is required because the cladding on the fuel cannot be verified to be intact and will be contaminated with cesium and strontium from a melter experiment upset condition. LWR SNF pins and pieces from the 325 and 327 Building hot cells will be transferred to the 324 Building RE Cells for decontamination and inclusion in the encapsulation. The fuel will be transferred to storage casks in the RE Cells' Air Lock and shipped to the 400 Area ISA for storage.

Pacific Northwest Laboratories (PNL) is currently procuring casks that will be qualified for both shipping and storage of the LWR SNF. The casks will be shipped to the 400 Area ISA for storage. PNL has accelerated activities to complete removal of the B Cell SNF by the end of 1996. The casks will later be relocated to the 200 Area ISA consistent with the FFTF SNF and subsequently shipped to INEL.

FFTF pins and pieces remaining at the 327 building will be returned to FFTF for disposition with the remainder of the FFTF SNF.

\subsubsection{T Plant SNF}

The planning basis for the 72 Shippingport PWR Core 2 assemblies stored at T Plant assumes that the SNF will be retrieved and placed in storage casks at the 200 Area ISA by December 2000 and later transferred to INEL. Use of a dual purpose storage and shipping cask is being considered along with storage in the CSB to reduce life-cycle costs. Because this SNF is compatible with storage and transport systems certified for commercial PWR SNF, dual purpose systems being developed for commercial SNF will be considered for use to minimize life-cycle handling of the SNF.

\subsubsection{PFP SNF}

Three dissimilar fuel types are or will be stored at PFP: LAMPRE SNF, FFTF SNF, and University of Washington High-Enriched Uranium SNF. Because of physical differences, the storage systems for each of these SNF types will vary. The planning basis assumes that these SNF inventories will remain at PFP until transport to INEL.

Currently, the LAMPRE SNF is packaged in three EBR-II casks, which have primarily been used as on-site transportation casks. The SNF was initially managed as Remote-Handled Transuranic material and has only recently been relocated to the protected area at PFP. The three casks are stored inside a concrete vault to provide an additional security barrier and 
supplement the casks' lead shielding. A review of the cask for continued dry storage until transfer to INEL will be completed by September 1996.

For transport to INEL, the LAMPRE SNF will be repackaged. The repackaging would occur at the CSB or the SMF (Shielded Material Facility) Hot Cell Air Lock in the 324 Building, where this SNF was repackaged when it arrived at the Hanford Site. A review of the existing storage cask will be completed by September 1996 to determine if repackaging is required prior to shipment to INEL. The current planning basis assumes that repackaging into NRF TRIGA casks will be completed at the CSB or 324 Building and the SNF subsequently returned to PFP for storage until transfer to INEL in the same package.

A small amount of highly enriched uranium fuel from the University of Washington is stored in a 55 gallon drum inside the 2736-ZB Building, also located in the protected area. This SNF will be repackaged prior to transport and shipped to INEL at the same time as the LAMPRE SNF.

The ISC's containing FFTF SNF designated for storage at PFP will be transported to an outdoor location inside PFP's protected area for storage on a precast concrete pad. This transfer is expected to take place by November 1998, but may be sooner depending on the staging of fuel for cleaning in the FFTF IEM Cell and the completion and approval of the onsite Safety Analysis Report for Packaging. To ship to INEL, the FFTF SNF will be transferred to the CSB, transloaded for off-site shipment, and the fuel and ISC transported in a similar manner as the remainder of the FFTF SNF.

\subsubsection{Burial Ground SNF}

The thirteen drums of Oregon State University (OSU) TRIGA SNF are buried under four feet of soil in Trench 7 of the 218-W-4C Burial Facility of the 200 West Area LLBG in TRIGA $^{\oplus}$ Standard Fuel Element Storage Drums. Each drum contains either six or seven TRIGA $^{\oplus}$ elements for a total of 90.

The SNF at the LLBG will be exhumed simultaneous with solid waste retrieval, which is currently anticipated in 2005. The NRF TRIGA ${ }^{\circledR}$ Cask designed for the 308 Building annex SNF will be used for interim storage and transport of the OSU TRIGA ${ }^{\circ}$ SNF once the drums are exhumed.

The OSU TRIGA fuel will be repackaged at either the CSB or the 324 Building, consistent with the LAMPRE SNF. The casks will be staged at the 200 Area ISA until transport to INEL. 


\subsubsection{Schedule Objectives}

Schedule objectives to achieve safe interim storage of other Hanford Site SNF include removal of SNF from the following existing storage facilities to support the Hanford Site cleanup mission:

- $\quad$ Fast Flux Test Facility. Complete activities to offload FFTF fuel currently stored in sodium to dry storage casks and ship sodium bonded SNF to INEL by October 1998 to enable facility deactivation.

- 308 Building. Complete activities to enable removal of the TRIGA fuel currently stored in the 308 Building reactor pool by September 1996 to enable deactivation of the facility. The fuel will be removed from the pool and transferred to dry storage.

- 324/325/327 Buildings. Complete packaging and transfer of 324 Building B Cell SNF to storage casks by December 1996. Complete removal of remaining SNF inventories currently in the buildings by September 1999.

- T Plant. Complete activities to remove SNF from T Plant by December 2000 to support the $\mathrm{T}$ Plant solid waste management mission.

Additional schedules are identified in the October 1994 document, Plan of Action to Resolve Spent Nuclear Fuel Vulnerabilities (Phase III) (DOE 1994a).

\subsubsection{Assumptions}

The scope identified in the Hanford Site SISMP for other Hanford SNF inventories are based on several key assumptions:

- Budget and manpower resources will be available in support of critical path activities.

- Current onsite transportation requirements identified in DOE-RL Order 5480.3 will not change.

- RCRA permitting and NRC licensing (or NRC review) will not be required for new storage systems for other Hanford Site SNF.

- $\quad$ Current safeguards and security requirements identified in DOE Order $\mathbf{5 3 3 3 . 2}$ will not change.

- The "Regionalization by Fuel Type" alternative identified in the SNF \& INEL EIS will be implemented, consistent with the DOE Integrated Spent Fuel Program's draft Interim Storage Plan. 


\subsubsection{Issues and Problems}

Critical issues that must be resolved to identify or implement actions at the Hanford Site, and items that could limit schedule performance, include the following:

- The applicability of RCRA to the SNF must be finalized. If RCRA is applied in the future, the path forward for management of these materials may be impacted.

- Regulatory authorities and licensing/permitting plans must be established. Licensing and/or permitting activities are likely critical path items. Regulatory jurisdiction could impact facility/storage criteria, near-term management, fuel conditioning, and fuel characterization requirements.

- Onsite transportation requirements must be maintained to enable onsite transport of SNF within schedule objectives. Offsite transportation capabilities must be developed to implement shipments to INEL.

- Adequate funding levels and funding stability for SNF management must be established.

- National SNF NEPA reviews must continue to progress on schedule and legal actions not impact implementation of actions identified in the SISMP. These NEPA reviews include: (1) the Environmental Impact Statement on a Proposed Policy for the Acceptance of United States Origin Foreign Research Reactor SNF; and (2) the SNF and INEL EIS.

- Programmatic ownership of materials after removal from current storage systems must be defined.

\subsubsection{Alternatives}

A formal systems engineering process is being used to establish and maintain a technical baseline for SNF management as described in Section 2.1.6. The systems engineering process scope includes other Hanford Site SNF inventories. Alternatives will be evaluated, when needed, using the systems engineering process.

Alternatives that have been identified, and in some cases dismissed, for other Hanford Site SNF include:

- Retaining fuel as-is in current facilities until issuance and implementation of the SNF and INEL EIS Record of Decision; 
- Locating the SNF on a common staging pad in the 200 Area or 400 Area to enable storage until the SNF and INEL EIS Record of Decision is implemented; and

- Utilizing the CSB for storage of other SNF;

- Repackaging and staging SNF storage within the current storage facilities until the SNF and INEL EIS Record of Decision is implemented.

As a planning basis, transfer of non-defense production reactor SNF from the Hanford Site to INEL is assumed, consistent with the SNF and INEL EIS "Regionalization by Fuel Type" alternative. Because of shipping logistics, the plan assumes storage of most of the FFTF SNF that is not sodium-bonded, the 308 Building SNF, and the 324/325/327 Building SNF at the 400 Area ISA and subsequent relocation to the 200 Area ISA prior to shipment off-site. To satisfy physical security requirements, the remaining FFTF SNF, the PFP SNF are planned for continued storage at PFP until transfer to INEL.

Current planned actions and potential alternatives will be evaluated based on requirements established in the Hanford Site Spent Nuclear Fuel Project (SNFP) Technical Baseline. Current planned actions will be supported, modified, or alternative approaches implemented based on the results of the evaluation. Transport and storage logistics for potential off-site shipments will be considered in conjunction with the DOE Integrated Spent Fuel Program Interim Storage Plan, which is currently being modified.

\subsubsection{Technology Development}

Technology development will be required to support ultimate disposition of other Hanford Site SNF. However, readily available commercial technologies are sufficient to achieve safe interim storage of most of this SNF. Technology development will be limited primarily to qualifying the defense production reactor SNF at the 105-K Basins, as described in Section 2.1.8, for dry storage. Detailed technology development needs will be finalized through the systems engineering process. Technology development activities will be integrated with other DOE complex development activities through the DOE Integrated Spent Fuel Program's Technology Integration Technical Working Group and documented in the DOE Spent Nuclear Fuel Technology Integration Plan (DOE 1994b).

\subsection{RESOURCES}

Funding will be required to support expense-related activities and acquisition of four major systems related to the $105-\mathrm{K}$ Basins path forward. Actions to implement interim storage of other Hanford Site SNF inventories are not within the scope of DNFSB Recommendation 94-1 and, therefore, the associated costs are not identified in the SISMP. 
Funding requirements to meet DNFSB Recommendation 94-1 IPP commitments for the 105-K Basins SNF are shown in Table 2-2. The total project costs, including continued 105-K Basins operations and maintenance, are also identified for reference purposes.

\subsection{WORK PLAN}

Cost and technical baselines for the activities defined in the Hanford SISMP will be monitored on a monthly basis, and variance reports will be submitted to RL by the Spent Nuclear Fuel Project on the seventh of each month. The variance report will cover any variation between the baseline and actual schedule for DNFSB Recommendation 94-1 commitments or actions that affect those commitments. Explanation of the variance and plans for necessary corrective action will be provided. The technical baseline is subject to formal change control.

The baseline schedule is provided in Volume 2 of the SISMP. DNFSB Recommendation 94-1 commitments are identified.

\subsection{STAKEHOLDER INVOLVEMENT}

Hanford Site stakeholders are involved in decisions related to Hanford Site SNF management through three separate, but related, venues:

- The Office of Spent Fuel Management's stakeholder involvement program, which deals primarily with higher-level SNF management policy issues;

- NEPA review public involvement activities, particularly those that will support Hanford Site-spetific SNF management, but also public involvement meetings for the EIS on a Proposed Policy for the Acceptance of United States Origin Foreign Research Reactor Spent Nuclear Fuel and the SNF and INEL EIS;

- The Hanford Site SNFP's site-specific stakeholder involvement program, which has focused significantly on the 105-K Basins path forward decision process.

The major Hanford Site stakeholders include: three major tribal governments (the Yakama Indian Nation, the Nez Perce Tribe, and the Confederated Tribes of the Umatilla Indian Reservation); the Hanford Advisory Board, which is primarily comprised of representatives from key Northwest public interest groups; and Hanford Site regulators, notably the State of Washington Department of Ecology and the U.S. Environmental Protection Agency. During the 105-K Basins fuel removal path forward decision process, input was requested from several stakeholder organizations, including the three major tribal governments and the Hanford Advisory Board's Major Safety and Waste Management Issues Working Group. 


\begin{tabular}{|c|c|c|c|c|c|c|c|c|c|c|}
\hline \multirow[b]{2}{*}{ Activity } & & \multicolumn{8}{|c|}{ ( $\$ S$ in millions) } & \multirow[b]{2}{*}{ Notes } \\
\hline & & FY 96 & FY 97 & FY 98 & FY 99 & FY 00 & \multicolumn{2}{|c|}{ FY 01} & TOTAL & \\
\hline Project & Expense & $\begin{array}{ll}\$ & 9.3 \\
\end{array}$ & $\$ 10.5$ & $\$ 10.0$ & $\begin{array}{ll}5 & 9.8\end{array}$ & $\begin{array}{l}\$ 8.0 \\
\end{array}$ & 3 & 4.4 & $\begin{array}{|ll|}S & 52.0 \\
\end{array}$ & \multirow{3}{*}{$\begin{array}{l}\text { Includes projoct integration and administration, } \\
\text { regulatory support, and public involvement. }\end{array}$} \\
\hline \multirow[t]{2}{*}{ Integration } & Capital & $\$$ & $s-$ & $\$$ & $\$$ & $\mathbf{s}$ & 3 & $\cdot$ & 5 & \\
\hline & Total & 9.3 & 10.5 & 10.0 & 9.8 & 8.0 & 5 & 4.4 & 52.0 & \\
\hline Systems & Expense & $\begin{array}{ll} & 15.2 \\
\end{array}$ & 11.1 & 8.7 & 2.6 & 1.5 & 3 & 0.0 & 39.1 & \multirow{3}{*}{$\begin{array}{l}\text { Includes systems engineering, process engineering, } \\
\text { technology acquisition, charnaterization, } \\
\text { technology program integration, and EIS support. }\end{array}$} \\
\hline \multirow[t]{2}{*}{ Integration } & Capital & $\$$ & - & $\$$ & $\$$ & $\$$ & 3 & - & $\$$ & \\
\hline & Total & 15.2 & 11.1 & 8.7 & 2.6 & 1.5 & 4 & 0.0 & 39.1 & \\
\hline \multirow{3}{*}{$\begin{array}{l}\text { MCO } \\
\text { System Acquisition }\end{array}$} & Expense & 2.7 & 6.2 & 28.3 & 10.8 & $\mathbf{s}$ & 3 & - & 48.0 & \multirow{3}{*}{$\begin{array}{l}\text { Includes design, fabrication, testing, qualification } \\
\text { and safety/regulatory documentation. }\end{array}$} \\
\hline & Capital & $s$ & $\$$ & $\$$ & $\$$ & $\$$ & 3 & - & $\$$ & \\
\hline & Total & 2.7 & 6.2 & 28.3 & 10.8 & $\$$ & 9 & - & 48.0 & \\
\hline \multirow{3}{*}{$\begin{array}{l}\text { Cask } \\
\text { Transportation System }\end{array}$} & Expense & 1.5 & 1.6 & 0.5 & - & $\$$ & 5 & - & 3.6 & \multirow{3}{*}{$\begin{array}{l}\text { Includes design, fabrication, testing, qualification } \\
\text { and safety/regulatory documentation. }\end{array}$} \\
\hline & Capital & 5.9 & $\$ 13.2$ & 1.2 & $s$ & $s$ & $s$ & - & 20.3 & \\
\hline & Total & 7.4 & $\$ 14.8$ & 1.7 & $s$ & $\$$ & 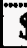 & $=$ & 23.9 & \\
\hline \multirow{3}{*}{$\begin{array}{l}\text { K Basin Material } \\
\text { Removal/Clean-Up }\end{array}$} & Expense & \& $\quad 25.2$ & $\$ 28.6$ & 16.4 & 19.2 & 20.5 & $s$ & 0.6 & s 110.5 & \multirow{3}{*}{$\begin{array}{l}\text { Includes fuel removal system acquisition; fiuel removal } \\
\text { operations; sludge debris, and } \\
\text { water removal system acquisition and operations; and } \mathrm{K} \\
\text { Basins facilities. }\end{array}$} \\
\hline & Capital & $s$ & s & $\mathbf{s}$ & $s$ & $s$ & s & - & & \\
\hline & Total & 25.2 & 28.6 & 16.4 & 19.2 & 20.5 & 5 & 0.6 & $\begin{array}{ll}\$ & 110.5\end{array}$ & \\
\hline \multirow[t]{3}{*}{ Canister Storage Building } & Expense & 1.7 & 5.6 & 8.9 & 9.4 & 5.7 & 3 & 0.7 & \begin{tabular}{|l|l|}
$\$ \quad 32.0$ \\
\end{tabular} & \multirow{3}{*}{$\begin{array}{l}\text { Includes acquisition of Canistor Storage } \\
\text { Building and operating costs through } 2001 .\end{array}$} \\
\hline & Capital & 38.7 & 39.1 & 1.7 & $\$$ & $s$ & 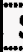 & - & $\$ 79.5$ & \\
\hline & Total & 40.4 & $\$ 44.7$ & 10.6 & 9.4 & 5.7 & 5 & 0.7 & $\$ 111.5$ & \\
\hline \multirow{3}{*}{$\begin{array}{l}\text { Fuel Conditioning } \\
\text { System(s) }\end{array}$} & Expense & 1.8 & $\begin{array}{ll}\quad 2.4 \\
\end{array}$ & 6.3 & 19.1 & $\$ 12.6$ & 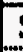 & - & $\begin{array}{|ll|}\$ \quad 42.2 \\
\end{array}$ & \multirow{3}{*}{$\begin{array}{l}\text { Includes acquisition of conditioning system(s) } \\
\text { \& operations costs. }\end{array}$} \\
\hline & Capital & 3.1 & $\$ \quad 26.7$ & 11.0 & $s$ & $s-$ & 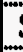 & - & 40.8 & \\
\hline & Total & 4.9 & $\begin{array}{ll}\text { \$ } 29.1 \\
\end{array}$ & 17.3 & 19.1 & 12.6 & s & - & $\$ \quad 83.0$ & \\
\hline \multirow{3}{*}{$\begin{array}{l}\text { Subtotal for K Basin } \\
\text { Spent Fuel } \\
\text { Path Forward }\end{array}$} & Expense & 57.4 & $S \quad 66.0$ & 79.1 & 70.9 & $\$ \quad 48.3$ & $s$ & 5.7 & S 327.4 & \multirow{6}{*}{$\begin{array}{l}\text { Includes surveillanco, maintenance, muclear material } \\
\text { management \& eccountability, training. } \\
\text { and readiness reviow. }\end{array}$} \\
\hline & Capital & 47.7 & S 79.0 & 13.9 & $s$ & $\$$ & 3 & - & $\begin{array}{|ll|}S & 140.6 \\
\end{array}$ & \\
\hline & Total & $\begin{array}{|ll|}S & 105.1 \\
\end{array}$ & $S \quad 145.0$ & 93.0 & 70.9 & 48.3 & $s$ & 5.7 & S 468.0 & \\
\hline \multirow[t]{3}{*}{ K Basin Operations } & Expense & 29.6 & 29.7 & 29.7 & 29.5 & 30.7 & & 5.3 & $\begin{array}{ll}\$ & 154.5\end{array}$ & \\
\hline & Capital & 5 & $\$$ & $s$ & $s$ & $s$ & 9 & - & $\$$ & \\
\hline & Total & $\$ 29.6$ & \begin{tabular}{|l|l|}
5 & 29.7 \\
\end{tabular} & 29.7 & 29.5 & 30.7 & 9 & 5.3 & $\$ 154.5$ & \\
\hline \multirow{3}{*}{$\begin{array}{l}\text { Subtotal with K Basin } \\
\text { Operations }\end{array}$} & Expense & $\begin{array}{ll}5 \quad 87.0 \\
\end{array}$ & $\begin{array}{l}S \quad 95.7 \\
\end{array}$ & $\begin{array}{ll} & 108.8 \\
\end{array}$ & S 100.4 & 579.0 & s & 11.0 & S 481.9 & \\
\hline & Capital & $\begin{array}{ll}\quad 47.7 \\
\end{array}$ & $S 79.0$ & $\begin{array}{ll} & 13.9 \\
\end{array}$ & $s-$ & $\$$ & 3 & - & $\begin{array}{ll} & 140.6 \\
\end{array}$ & \\
\hline & Total & \begin{tabular}{|lll}
$S$ & 134.7 \\
\end{tabular} & \begin{tabular}{|l|l|l|}
$S$ & 174.7 \\
\end{tabular} & $S 122.7$ & $S 100.4$ & 579.0 & s & 11.0 & $S 622.5$ & \\
\hline
\end{tabular}

Dath is from Multi Your Program Plan (MYPP) submittal detod $9 / 95$ for the Hanford Spent Nuclear Fuel Projoct. Budget associated with deactivation of the

K Basins \& Fuel Conditioning Facilities and non-K Basins Hanford SNF is not included in this thble. 
The input was used to compile a listing of public and tribal values that was incorporated as criteria in the 105-K Basins path forward decision process. Stakeholder feedback on the decision was also requested. Significant stakeholder involvement in implementation of the path forward will continue. 
WHC-EP-0853 REV. 1

This page intentionally left blank. 


\subsection{PLUTONIUM-BEARING MATERIALS}

This portion of the Hanford SISMP covers the stabilization and storage or disposal of plutonium-bearing material in inventory at the Westinghouse Hanford Company-operated facilities at the Hanford Site and those materials (non-waste) arising from terminal cleanout of Hanford Site facilities. The work is in response to Defense Nuclear Facilities Safety Board Recommendation 94-1, dated May 26, 1994. This SISMP also includes specific corrective actions identified in the Plutonium Vulnerability Management Plan (DOE 1995c).

For stabilization considerations, plutonium-bearing material has been grouped into the following three categories:

- Solutions

- $\quad$ Residues and Oxides ( $<50$ weight percent [wt\%] Pu)

- Metals and Oxides ( $>50 \mathrm{wt} \% \mathrm{Pu})$

The Plutonium Finishing Plant (PFP) can stabilize and store or dispose of as transuranic waste all of these materials in the current inventory, and from the Hanford Site's terminal cleanout operations, with additions of glovebox-scale processing capability. Some development work will be required, depending on the final selection of stabilization technology. The current capability at PFP is small, limited to two muffle furnaces in one glovebox currently stabilizing plutonium residues at about 20 to 30 items per month.

Processing enhancements needed to complete the Hanford Site stabilization program in response to Recommendation 94-1 by May 2002 have been identified; these enhancements are covered in more detail in this SISMP. The SISMP also covers specific corrective actions from the Plutonium Vulnerability Management Plan. The capability from the PFP processing systems would be available for other U.S. Department of Energy sites and/or other Hanford Site requirements, if necessary, after completion of this program.

Preliminary resource-loaded schedules and funding profiles are included in this SISMP. A total of $\$ 130$ to $\$ 160$ million above routine facility operational costs over 7 years will be required to execute this plan. Four site specific concerns have been identified:

- Radiological dose to personnel associated with the work

- Availability of experienced personnel

- NEPA and RCRA compliance and permitting constraints

- Interaction with the International Atomic Energy Agency (IAEA) 


\subsection{INTRODUCTION}

\subsubsection{Background/Objective}

The Hanford Site has completed its production mission and is now beginning its new mission of environmental restoration. Part of the new mission is to stabilize and suitably store or dispose of all plutonium-bearing material. This includes plutonium-bearing material in storage at the PFP and material arising from terminal cleanout at PFP and other Hanford Site facilities.

\subsubsection{Purpose}

The purpose of this portion of the SISMP is to develop the approach that will be used at the Hanford Site for the stabilization and safe storage of plutonium-bearing material. The SISMP will also identify processing capabilities at the Hanford Site that could be available to support cleanup at other DOE sites.

\subsubsection{Scope}

The SISMP encompasses WHC held plutonium-bearing materials at the Hanford Site, and excludes the items currently held by Pacific Northwest Laboratories (PNL). Coordination with PNL is currently underway and it is expected that PNL activities will be included in the next semiannual revision of this document. Table 3-1 shows that the WHC material totals about 4 metric tons, net weight, of plutonium distributed among approximately 8,038 items. The items constitute a wide range of chemical and physical properties, including metals, oxides, ash, sludges, solutions, combustibles, and other residues.

Necessary storage capability for the stabilized material from the processing operations is also included in the SISMP. The storage of the FFTF unirradiated fuel assemblies is addressed in this plan but no actions are required. These assemblies are considered stable and suitable for 50 -year storage as is.

\subsubsection{Summary}

This program plan addresses the stabilization and repackaging of two groups of plutonium materials:

(1) Materials which have a plutonium assay $>50 \mathrm{wt} \%$ plutonium, and

(2) Materials which have a plutonium assay $<50 \mathrm{wt} \%$ plutonium.

Materials which are $>50$ wt\% plutonium will be stabilized and packaged to specifications in the DOE Standard - Criteria for Safe Storage of Plutonium Metals and Oxides (DOE-STD3013-94). Materials which are <50wt\% plutonium are outside the scope of this DOE storage standard. DOE is currently developing a standard for the $<50 \mathrm{wt} \%$ plutonium materials. Until this standard is issued, Hanford will continue to stabilize these residues to 
WHC-EP-0853 REV. 1

Table 3-1. Inventory of Plutonium-Bearing Materials.

\begin{tabular}{|c|c|c|}
\hline Material Type & No. of Items & $\mathrm{Pu}$ in $\mathrm{Kgs}$ \\
\hline \multicolumn{3}{|c|}{ Metals and Oxides addressed by DOE-STD-3013-94 } \\
\hline Metal & 352 & 736 \\
\hline Oxides $>50 \mathrm{wt} \% \mathrm{Pu}$ & 2647 & 1849 \\
\hline Subtotal & 2999 & 2585 \\
\hline \multicolumn{3}{|c|}{ Materials to be converted to meet DOE-STD-3013-94 } \\
\hline Solutions & 459 & 335 \\
\hline Polycubes & 251 & 34 \\
\hline Subtotal & 710 & 369 \\
\hline \multicolumn{3}{|c|}{ Materials to be addressed by the Residue Standard } \\
\hline Oxide $<50 \mathrm{wt} \% \mathrm{Pu}$ & 553 & 91 \\
\hline Mixed Oxides & 2296 & 323 \\
\hline Alloys & 125 & 34 \\
\hline Ash & 551 & 81 \\
\hline Slag and Crucible & 266 & 43 \\
\hline Sources & 214 & 24 \\
\hline Compounds & 27 & 4 \\
\hline Other/Miscellaneous & 107 & 6 \\
\hline Other Combustibles & 22 & 1 \\
\hline Subtotal & 4161 & 607 \\
\hline \multicolumn{3}{|c|}{ Materials stored in exception to either standard } \\
\hline Fuel Pin Assemblies & 168 & 714 \\
\hline Grand Total & $8038^{*}$ & $4274^{*}$ \\
\hline
\end{tabular}

* Figures do not include plutonium held by PNL (approximately $3 \mathrm{kgs}$ ) 
the stabilization criteria in DOE-STD-3013-94 $\left(1000^{\circ} \mathrm{C}\right.$ and $0.5 \%$ LOI). These materials will then packaged for safe interim storage per Hanford's existing packaging standard pending the implementation of the DOE standard packaging system.

Capability does not currently exist to package any materials to the requirements established in the DOE storage standard, however some capabilities (two muffle furnaces) do exist to stabilize materials as specified in this storage standard. In addition, more stabilization capabilities will be established prior to the earliest date that packaging capabilities utilizing containers specified in the DOE storage standard can be established. The ability to quickly establish these packaging capabilities are limited by the need for: (1) development of the technology and automated equipment for loading material into and sealing the boundary container, and (2) modification of the existing storage vault to accept the required storage containers. Hanford will work closely with the DOE complex in the development, consolidated procurement, and implementation of the DOE standard packaging system.

Stabilization activities must proceed on an aggressive schedule in order to accomplish 94-1 programmatic goals, consequently it is not possible to wait for the necessary packaging capabilities to be established. An interim packaging capability will be established such that stabilized material can be packaged in such a way that restabilization is not necessary at the time it is eventually placed and sealed inside a boundary container. In order to move forward with stabilization activities, it is proposed that a new Hanford material container will be designed to store stabilized materials in the interim period. The new material container will be sealed without plastic or organics in order to meet specifications of the DOE storage standard, and will be designed to be placed directly into a boundary container. In the interim time period before boundary container loading can be accomplished, the new material container will be packaged into existing containers for placement into the existing vault, using standard Hanford bag out and packaging procedures. When capabilities for loading and storing boundary and primary containers are established, the material containers can be loaded into the packaging glovebox and then placed into boundary containers without the use of any organic material. The seal on the material containers will ensure that the material has not been re-exposed to any glovebox atmosphere, and that it has maintained the necessary characteristics established during the stabilization processing.

Most plutonium materials in storage at Hanford will be evaluated for potential discard to WIPP to avoid unnecessary costs, handling, and personnel exposure. It is anticipated that many low assay materials may be discardable, along with some materials of small quantity which would require special processing for safe long term storage. For materials which are not discardable, the baseline plan is to utilize three primary processes to stabilize materials prior to packaging for storage. These are:

(1) thermal stabilization in muffle furnaces for non combustible solids and sludges, with the option to install a continuous system for stabilization of oxides (both greater than $50 \mathrm{wt} \%$ and less than 50wt\%)

(2) thermal stabilization in a pyrolysis furnace for combustible solids, and

(3) denitration of solutions in a vertical calciner. 
Current process capability consists of two muffle furnaces in Glovebox HC-21C for thermal stabilization. Up to 9 additional muffle furnaces will be installed in gloveboxes HA-21I, $\mathrm{HA}-20 \mathrm{MB}$, and in one additional glovebox in room 235B. The exact location of the continuous calciner has not yet been determined. The thermal stabilization process will be used to treat sludges and reactive solids first, and then be used to process the interim stable portion of the inventory.

Combustible solids, mainly polycubes, will be treated in a pyrolysis furnace. It's design will be based upon a system previously used for treating this material, with modifications to improve off gas handling capability. The location of the replacement system has not been determined but is likely to be collocated with the other stabilization activities in room $235 \mathrm{~B}$.

Plutonium-bearing solutions will be processed in a vertical calciner, utilizing a direct denitration process. A prototype is currently being fabricated and installed in a PFP Process Support Laboratory (PPSL) glovebox with development activities scheduled to be completed later this year. The denitrator may require an additional thermal stabilization step to meet storage standards, but considerations are being given to the possibility of raising the calciner operating temperature to meet the standard in a single step. Work is also underway to identify what pretreatment would be required for solutions that are not directly suitable for denitration, such as concentrated filtrate.

A summary material flow diagram for the baseline material stabilization process is given in Figure 3-1, and a building layout showing tentative glovebox location is shown in Figure 3-2. Process and equipment development support for these activities are being provided by the PPSL.

Preliminary schedules show completion of stabilization processing, repackaging, and storage of all materials in the year 2002. Table 3-2 shows a matrix of the scheduled milestones and their relationship to the resolution of the concerns raised in DNFSB Recommendation 94-1. This schedule is based upon expedited funding resources and shift operations for 24 hours/day, 5 days/week. Activities to be accomplished within the first three years include:

(1) stabilization of 220 liters of chloride and miscellaneous solutions,

(2) stabilization of 46 items of incinerator ash,

(3) development of a new Hanford material container,

(4) evaluation of plutonium materials in inventory for discard, and

(5) completion of necessary PFP NEPA activities.

Uncertainties exist with respect to acquiring adequate amounts of technical personnel for providing the necessary engineering work, and the ability to automate planned operations to assure acceptable exposure limits are not exceeded. 


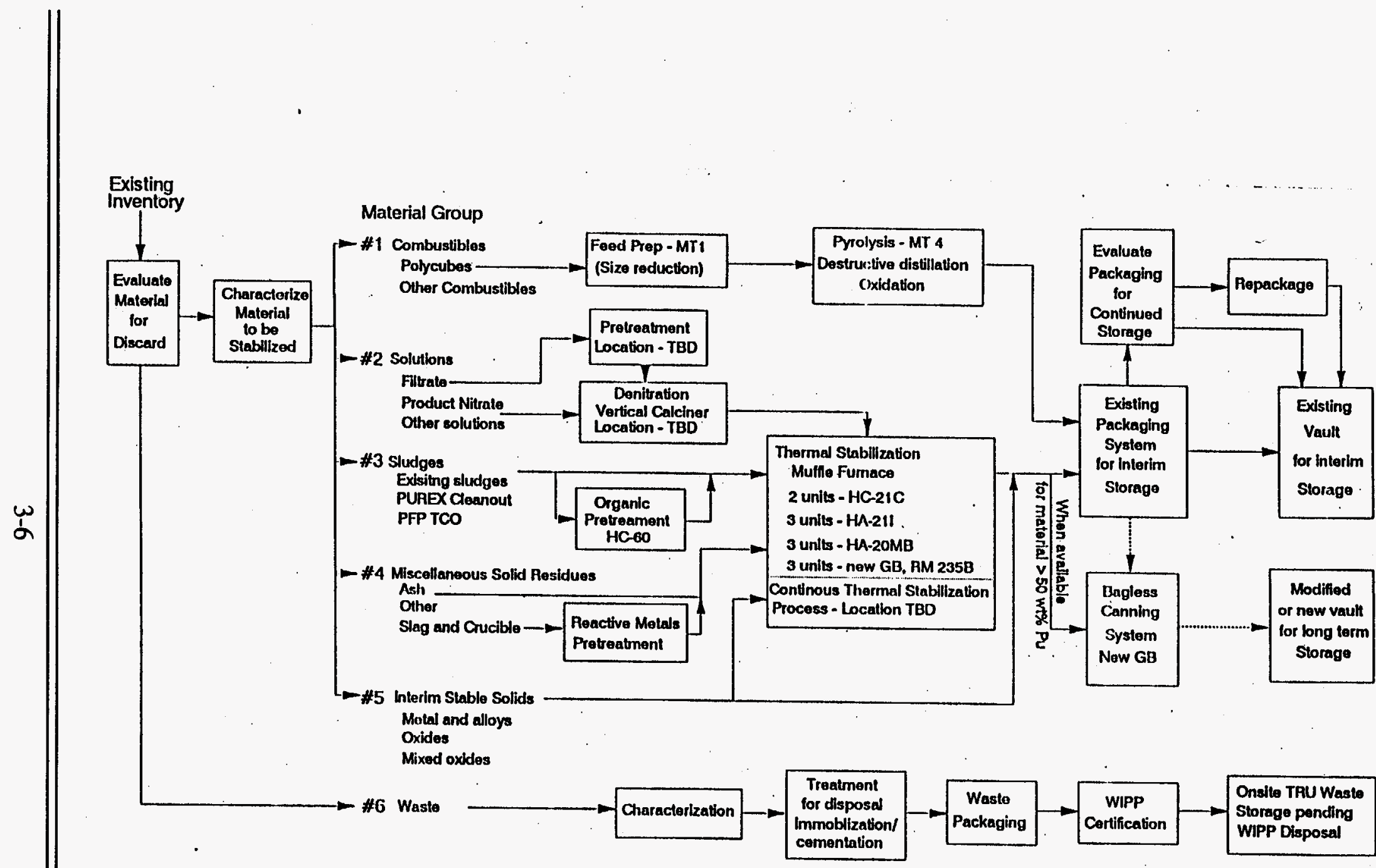


Figure 3-2. PFP Building Layout - Location of Process Areas.

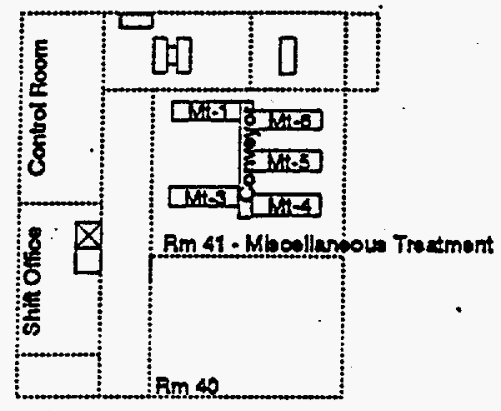

4 Floot - 236-Z Bullding

Location of Pyrolysis Procoss Area

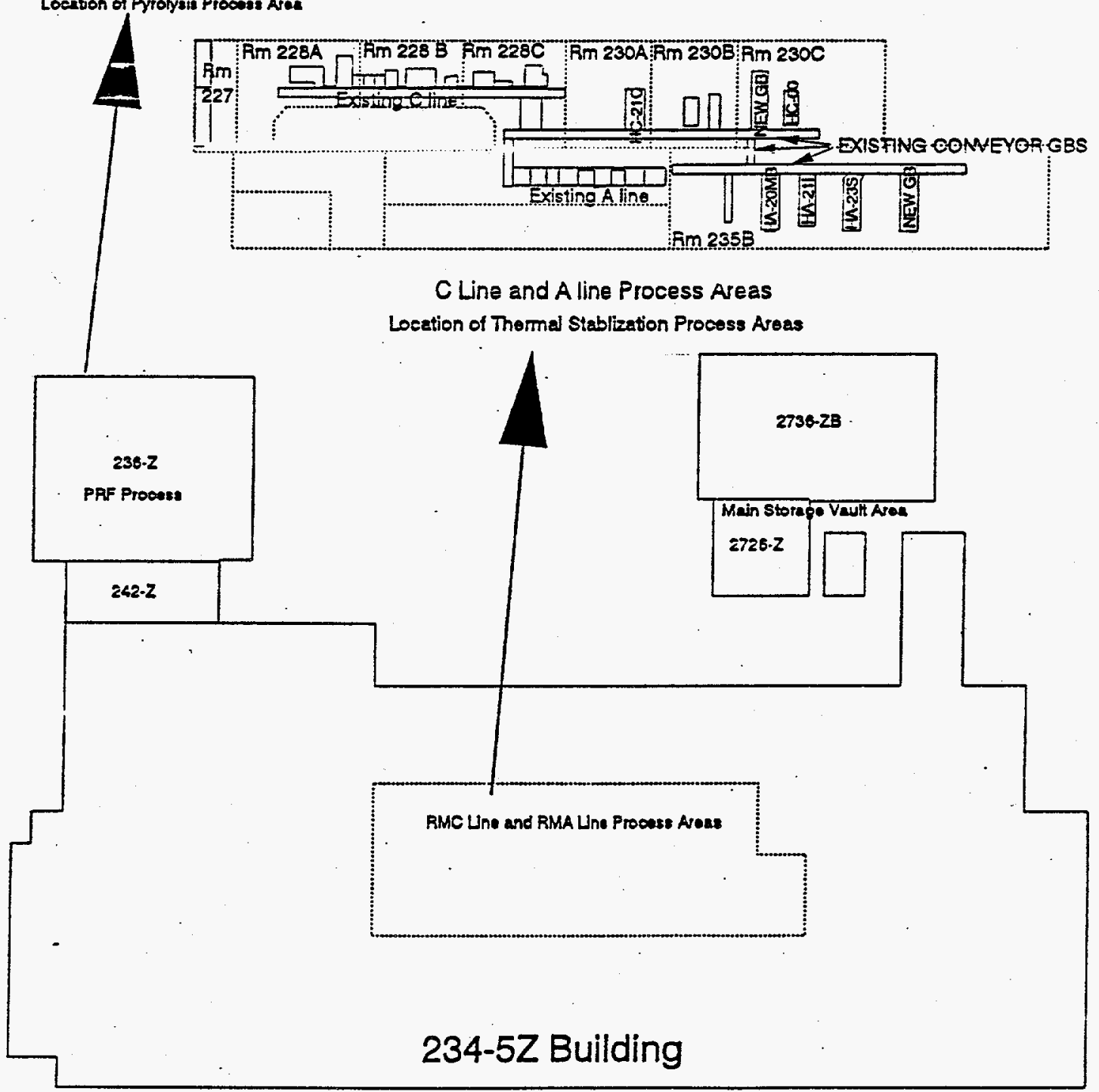


Table 3-2. Milestone Summary.

\begin{tabular}{|c|c|c|}
\hline Activity & Milestone & Comments \\
\hline Issue Material Characterization Plan & March 1995 & Completed March 1995 \\
\hline $\begin{array}{l}\text { Initiate and complete transfer of PUREX } \\
\text { solutions to tank farms for disposal. }\end{array}$ & August 1995 & $\begin{array}{l}\text { IP-3.1-023 \& IP-3.1-024; } \\
\text { Completed April 1995. }\end{array}$ \\
\hline $\begin{array}{l}\text { Start engineering studies of a new } \\
\text { repackaging line at Hanford }\end{array}$ & September 1995 & $\begin{array}{l}\text { IP-3.2-028; Completed July } 1995 \\
\text { The studies have been replaced by the } \\
\text { consolidated procurement effort. }\end{array}$ \\
\hline Stabilize sludge residue inventory. & September 1995 & IP-3.3-031; Completed June 1995. \\
\hline Submit discard limit request & September 1995 & $\begin{array}{l}\text { For U.S. Department of Energy, } \\
\text { Headquarters (DOE-HQ) approval }\end{array}$ \\
\hline Stabilize high-risk solutions & September 1995 & $\begin{array}{l}220 \text { liters (27 items) containing chlorides } \\
\text { and fluorides in PFP Process Support } \\
\text { Laboratory. IP-3.1-015 }\end{array}$ \\
\hline Verify venting of solution containers & December 1995 & IP-3.1-014; Completed May 1995. \\
\hline Stabilize high-risk incinerator ash & March 1996 & $\begin{array}{l}\text { IP-3.3-032; } 46 \text { items of reactive } \\
\text { incinerator ash }\end{array}$ \\
\hline $\begin{array}{l}\text { Complete solution technology development } \\
\text { at PFP }\end{array}$ & March 1996 & $\begin{array}{l}6 \text { stabilization methods under evaluation. } \\
\text { IP-3.1-021 }\end{array}$ \\
\hline Feasibility of Calciner Modification & March 1996 & $\begin{array}{l}\text { Impacts decision on use of new vs. } \\
\text { existing development model }\end{array}$ \\
\hline Provide Hanford storage container & May 1996 & $\begin{array}{l}\text { Organic-free container suitable for } \\
\text { insertion into DOE Standard boundary } \\
\text { container }\end{array}$ \\
\hline Issue Dose Evaluation Study & June 1996 & Impacts design of process systems \\
\hline PFP EIS-ROD & June 1996 & IP-3.1-016 \\
\hline Begin processing solutions at PFP & June 1997 & $\mathrm{IP}-3.1-022$ \\
\hline $\begin{array}{l}\text { Project Validation New Packaging and } \\
\text { Storage System }\end{array}$ & July 1997 & CDR \& cost estimate completed \\
\hline $\begin{array}{l}\text { Complete detailed design, equipment } \\
\text { procurement, and installation of a new } \\
\text { repackaging system at Hanford }\end{array}$ & December 1998 & IP-3.2-029 \\
\hline Complete stabilizing remaining solutions & January 1999 & $\begin{array}{l}\text { IP-3.1-017; } 4,800 \text { liters, } \\
450 \text { items of solution }\end{array}$ \\
\hline Start restabilizing high assay oxides at PFP & July 1999 & IP-3.2.033 \\
\hline Begin stabilization of polycubes. & July 1999 & IP-3.3-028 \\
\hline $\begin{array}{l}\text { Train staff, prepare procedures, perform } \\
\text { operational readiness testing (prior to } \\
\text { commencing operations) }\end{array}$ & September 1999 & IP-3.2-030 \\
\hline
\end{tabular}


WHC-EP-0853 REV. 1

\begin{tabular}{|l|l|l|}
\hline \multicolumn{1}{|c|}{ Activity } & \multicolumn{1}{|c|}{ Milestone } & \multicolumn{1}{|c|}{ Comments } \\
\hline $\begin{array}{l}\text { Commence repackaging operations at } \\
\text { Hanford }\end{array}$ & October 1999 & IP-3.2-031 \\
\hline Complete stabilize reactive solid residues & January 2000 & $\begin{array}{l}\text { IP-3.3-026; Sand, slag, \& crucible, and } \\
\text { poorly characterized items }\end{array}$ \\
\hline Complete metal repackaging at Hanford. & September 2000 & IP-3.2-032 \\
\hline Complete stabilization of polycubes. & January 2001 & IP-3.3-029 \\
\hline Complete stabilize remaining residues & January 2002 & $\begin{array}{l}\text { Items currently meeting Hanford Site } \\
1.0 \text { wt\% LOI at 450 C }\end{array}$ \\
\hline Complete stabilize high-assay oxides & January 2002 & $\begin{array}{l}\text { Items currently meeting Hanford Site } \\
1.0 \text { wt\% LOI at 450 C C }\end{array}$ \\
\hline $\begin{array}{l}\text { Complete recovery of non-waste plutonium } \\
\text { Ianuary 2002 }\end{array}$ & $\begin{array}{l}\text { Approximately 56 kg of plutonium is } \\
\text { held up in process systems and support } \\
\text { equipment }\end{array}$ \\
\hline $\begin{array}{l}\text { Complete thermally stabilize and } \\
\text { repackage all plutonium oxide to meet the } \\
\text { metal and oxide storage standard. }\end{array}$ & May 2002 & IP-3.2-018; IP-3.2-034 \\
\hline $\begin{array}{l}\text { Complete stabilizing and packaging all } \\
\text { remaining residues. }\end{array}$ & May 2002 & IP-3.3-033 \\
\hline
\end{tabular}

\subsection{SOLUTIONS}

\subsubsection{Scope}

The scope of this portion of the Hanford SISMP, addressing remediation of solutions, is the current inventory of plutonium-bearing solutions at PFP and PUREX. The inventory at PFP consists of approximately 4,804 liters of solution: 4,564 liters of nitrate solutions; 220 liters of chloride and miscellaneous solutions; and 20 liters of organic solutions. These solutions are in 10-liter containers in storage in the 234-5Z Building. Of these, the 220 liters of chloride, fluoride-contaminated, and miscellaneous solutions are being used for developmental testing and are scheduled to be stabilized by the end of 1995 . The chloride and fluoride solutions are considered to be the greatest risk to container integrity, and therefore are receiving early attention.

All covered solutions at PUREX have been discarded to Hanford waste tanks.

\subsubsection{Remediation Objectives}

The objective is to transform the current inventory of solutions to a stable form suitable for 50-year storage. Additionally, this remediation effort will ensure that the solution containers are properly vented until they are emptied and stabilized. The product form for the stabilized solutions will be plutonium oxide fired to the temperature $\left(1000^{\circ} \mathrm{C}\right)$ necessary to meet the DOE standard for 50-year storage. Most of the stabilized material will be $>50 \mathrm{wt} \%$ 
plutonium necessitating ultimate packaging to the DOE Standard, DOE-STD-3013-94. Concurrent with the development of a packaging system that will comply with DOE-STD-3013-94, Hanford Site personnel will develop a material container that will ensure the stabilized plutonium-bearing materials in the Hanford container will remain suitable for overpack in the DOE-STD-3013-94 boundary container without repackaging. This involves the development of a food-pack-style container of proper size that is free of organics and is hermetically sealed.

Consideration will be given to immobilizing and discarding the 20 liters of organic solution as well as other miscellaneous solutions that are not compatible with the planned processing capability without extensive pretreatment.

\subsubsection{Remediation Process}

Hanford Site laboratory personnel are currently performing developmental testing of equipment and processes to determine the appropriate method for stabilizing the solutions. of greatest interest are direct calcination using a continuously operating vertical calciner, and a batch-operated precipitation/filtration/thermal stabilization process. The vertical calciner may also need a downstream thermal treatment step to meet the $1000^{\circ} \mathrm{C}$ criterion, and the plan assumes that all of the vertical calciner product will be treated in a muffle furnace. An engineering study will be conducted in close concert with the above development program to determine the appropriate process improvements and to select the location within the 234-5Z Building.

All liquid waste generated from the solution stabilization process will be routed through existing systems and disposed of to the Hanford Site waste tanks in accordance with the current waste tank acceptance criteria.

\subsubsection{Schedule Objectives}

Schedule details for solution stabilization are shown in Appendix B of Volume 2 of this report. The current developmental testing effort is projected to be completed in March 1996 with the first tests of the vertical calciner starting in June 1995. Tests on the precipitation/filtration process are already underway. The engineering study will begin concurrently with the start of vertical calciner testing; completion is expected in December 1995. Design of the selected system will proceed concurrently with the public review and comment period on the draft PFP NEPA document(s), starting November 1995.

Procurement and installation of the selected system will begin upon issuance of the approved NEPA documentation, June 1996. Initial startup of the new system is anticipated in July 1997 with a projected throughput of 275 liters of feed per month reached by January 1998. With this throughput, stabilization of the solutions is projected to be completed in January 1999. Concurrent with the denitration of the solutions will be additional thermal treatment of the calciner product (if required) using the existing muffle furnaces. The discardability of 
economics of storage versus disposal. Current U.S. Department of Transportation regulations (49 CFR 172 and 173) make shipment of solutions to another site nonviable.

\subsubsection{Technology Development}

Work in the PFP Process Support Laboratory, to be completed by the end of March 1996, will develop and demonstrate the technology to be used at PFP for stabilization of aqueous plutonium solutions.

\subsection{RESIDUES AND OXIDES ( $<50 \mathrm{wt} \%$ Pu)}

\subsubsection{Scope}

This material category includes the following:

- Plutonium residues and wet solids left over from operations of the Plutonium Reclamation Facility (PRF), generated from cleanout of process gloveboxes and equipment, or recovered during the terminal cleanout of process support equipment and ductwork (up to $56 \mathrm{~kg}$ of plutonium could be recovered). Material recovered to date is currently stored in gloveboxes at buildings $234-5 Z$ and $236-Z$. This category also includes plutonium-bearing material generated as a result of cleanout of other Hanford Site plutonium facilities such as the PUREX Plant.

The backlog inventory of low-organic ( $<2 \mathrm{wt} \%$ organic) sludge residues at the PFP ( 236 items) has been stabilized to $1000^{\circ} \mathrm{C}$ and $0.5 w t \%$ LOI using muffle furnaces (NOTE: five items had anomalies with LOI testing. Two had gains on ignition and three had high LOIs between 0.5 to $1.0 \mathrm{wt} \%$ ).

High-organic sludges ( $>2 \mathrm{wt} \%$ organic) may be generated during terminal cleanout of the PRF and will either have to be hydrolyzed for organic destruction before thermal stabilization or limited to small furnace batches because of their explosion hazard. A safety appraisal is needed to determine the safe batch size. Much of the material arising from terminal cleanout work at PFP and PUREX will be immobilized and discarded as waste, but some sludge may have sufficient plutonium content to warrant stabilization and recovery. The stabilization process would be the same as for the other sludges, with or without hydrolysis, as appropriate. The stabilization of fluoride bearing residues is being evaluated. The primary concern associated with the thermal stabilization of these materials is corrosion of equipment and the acceptable form required in the to-be-issued residue standard. The process planning at this time assumes, conservatively, thermal stabilization of all the terminal cleanout material.

- Plutonium-bearing residues such as sand, slag, and crucible, incinerator ash, and other miscellaneous dry residues from prior process operations, some containing fluorides, that are not considered stable for long-term storage. Vault storage has been 
allowed through special exemptions and special packaging in the existing Hanford Site storage criteria. The inventory of these residues includes approximately 1,625 items with a bulk weight of about $1,893 \mathrm{~kg}$. These items are in the 234-5Z, 2736Z, and 2736-ZB Building storage vaults.

- Combustible solids including PFP's current inventory of polycubes and miscellaneous plutonium-bearing solids such as rags, filter media, paper, and plastics, as well as any such material generated from the ongoing cleanout of the plant. The inventory of combustible solids includes approximately 251 items containing 1,800 polycubes of various sizes with approximately $34 \mathrm{~kg}$ of plutonium, total. The miscellaneous combustible solids are contained in 22 items of $64 \mathrm{~kg}$ bulk weight. The miscellaneous combustible solids include high-efficiency particulate air filters, contaminated insulation, graphite composites, etc. These items are not an imminent hazard because they are not susceptible to spontaneous combustion, and they are packaged and stored in such a way as to allow proper venting.

- All other solid, plutonium-bearing residues containing less than $50 \mathrm{wt} \%$ plutonium. This includes about 2,200 items with about $3,000 \mathrm{~kg}$ bulk weight of oxides which are interim stable based on their previous thermal treatment. This material is currently stored in the $2736 \mathrm{Z}$ and $2736 \mathrm{ZB}$ Vaults.

- FFTF unirradiated fuel pins and assemblies in storage at PFP.

\subsubsection{Remediation Objectives}

The objective of this remediation is to transform the plutonium-bearing residues to a stable plutonium oxide form suitable for long-term storage. Most of the residues have low plutonium content ( $<50 \mathrm{wt} \%$ plutonium) and will not come under the DOE Standard (DOE-STD-3013-94) for 50-year storage. The DOE is currently developing a standard for the stabilization and storage of plutonium residues. Current drafts of the standard support the Hanford approach for stabilization using thermal treatment. Hanford is currently using the DOE-STD-3013-94 requirements $\left(0.5 \mathrm{wt} \%\right.$ loss on ignition at $\left.1000{ }^{\circ} \mathrm{C}\right)$ for these residue materials.

Until the DOE standard packaging system is available for use at PFP, packaging and storage will be according to Hanford Site criteria, modified to include use of an organic-free material container, starting in May 1996. Significant consideration will be given to disposal of the lowest plutonium assay items as TRU waste. Analyses are underway to determine discard limits of plutonium-bearing residues based on the relative costs of processing and vault storage versus discard and disposition as TRU waste.

The unirradiated FFTF fuel pins and assemblies are considered acceptable as-is for long term storage. No further actions are envisioned for these materials. 


\subsubsection{Remediation Processes}

The current process for stabilization of plutonium-bearing sludge residues is thermal treatment in one of two muffle furnaces located in Room 230-A of the 234-5Z Building. Figure 3-2 shows the location of the existing and proposed process equipment. Furnace temperatures are regulated to first vaporize volatile material at low temperature $\left(\sim 200^{\circ} \mathrm{C}\right)$ and then to raise temperatures ultimately to $1000{ }^{\circ} \mathrm{C}$ for final stabilization to the desired end point. After a minimum 1-hour soak at the maximum temperature (approximately $10 \%$ of the sludge items and the majority of the reactive incinerator ash items require up to a 3 hour soak time), the material is allowed to cool in a controlled environment and packaged to existing Hanford Site criteria.

High-organic sludge residues will require pretreatment prior to stabilization. The pretreatment process, hydrolysis, is partially installed in glovebox HC-60 (room 230-C). Complete installation, testing, and readiness review are required prior to startup.

Most of the other residues will be stabilized by thermal treatment in muffle furnaces. Some of the material will require a two-stage heating cycle to drive off volatiles at a lower temperature before increasing the temperature to the $1000^{\circ} \mathrm{C}$ end point. After a minimum 1-hour soak at the high temperature, the material will be allowed to cool in a controlled environment and packaged to Hanford Site's criteria, including use of an organic-free material container starting in May 1996.

The polycubes will require a different process to decompose and separate the polystyrene from the plutonium oxide. The polycubes will be cut into pieces (with a maximum size of approximately $65 \mathrm{~cm}^{3}\left(4 \mathrm{in}^{3}\right)$, resulting in approximately 2,700 polycube pieces) and then treated in a two-stage pyrolysis furnace that will be set up to decompose and vaporize the polystyrene, burn off the residual carbon, and stabilize the residual plutonium oxide. This process is essentially the same as that previously used for polycube stabilization (located in glovebox MT-4 of the 236-Z Building) until it was shut down for an offgas problem. Figure 3-2 shows the location of this existing glovebox. The unit to be utilized for the stabilization outlined in this plan is likely to be located in room 235B of the 234-5Z Building. The system will have to be revamped to improve the flow characteristics of the inert gas from the glovebox into the decomposition furnace and to improve its offgas treatment capability.

If discarding of the miscellaneous combustibles is not practicable, thermal stabilization, leaching or acid washing will be considered. Any resulting solutions would be stabilized using the solution process discussed above.

Many of the items currently stored in PFP's vaults are not fully characterized. Specifically, there is a lack of information regarding the non-plutonium constituents. Some characterization will be required to stabilize or discard this material. Upgrades to the PFP laboratory have been identified to provide characterization capability, and these upgrades are included in Section 3.4. 
The FFTF unirradiated fuel is already stable and packaged to 50-year criteria so no effort other than storage of the containers is required.

\subsubsection{Schedule Objectives}

Details for stabilization of sludges and other miscellaneous solid residues are shown in Appendix B of Volume 2 of this report. The operation of the existing two muffle furnaces (covered by an approved environmental assessment) is ongoing. The stabilization of the original inventory of 236 low organic sludges was completed in June 1995. Because of their past history of container pressurization, 46 items of reactive incinerator ash will be stabilized now that the sludge stabilization campaign has been completed. Present NEPA documentation for operating the furnaces allows both sludge and the incinerator ash to be stabilized by March 1996. Stabilization of the 46 items of reactive incinerator ash is ongoing (milestone IP-3.3-032; complete stabilization by March 1996). The furnaces will then be available to process other material once NEPA documentation in the form of a revised Environmental Assessment is completed.

Sludges recovered from the terminal cleanout activities will be stabilized in the same year they are generated, starting in October 1995, using the two existing furnaces, supplemented as necessary with new furnaces coming into service in July 1996. Operations on sludge stabilization, in connection with terminal cleanout, will continue until the end of the PFP cleanout program in January 2005.

Six new muffle furnaces will be installed in existing gloveboxes HA-21I and HA-20MB in Room 235-B of Building 234-5Z, three furnaces to a glovebox. The six furnaces will be ready for operation beginning in July 1996. Figure 3-2 shows the location of these gloveboxes. With a three-shift operation, these six furnaces have a throughput capacity of about $1,400 \mathrm{~kg}$ of bulk solids per year. An additional three furnaces are projected to be installed in room 235-B of the 234-5Z Building and will be ready for operation in August 1997. Eleven furnaces are expected to bring the total processing capacity to about $2,500 \mathrm{~kg}$ per year. This sequence of furnace capacity increases would permit completion of stabilization of miscellaneous solid residues in 1998. The schedule would improve depending upon the amount of miscellaneous solid residues that can be discarded as TRU solid waste.

Details for stabilization of the polycubes are shown on the attached schedule. The pyrolysis furnaces will be revamped and ready for full operation at a capacity of about 2,000 polycube pieces per year starting by March 1999 . The campaign is expected to be completed by January 2001. Based on the current schedule for completion of the new packaging, loadout, and storage capability, June 1998, most of the product can concurrently be packaged and stored to the DOE standard.

The miscellaneous combustibles will be evaluated for discard as waste with a request for discard being forwarded to RL for approval by September 1995. Those items approved for discard will be packaged, and discarded as TRU solid waste within 90 days of receipt of discard authority. Those not approved for discard will be further evaluated to determine the 
proper stabilization process. The process selection process is expected to take nine months, with a determination completed by July 1996.

The PFP Analytical Laboratory is expected to be upgraded. Additional instrumentation will be provided to support necessary analyses in characterization of miscellaneous solid residues and process support of the stabilization operations. The laboratory upgrade is expected to be complete by September 1997.

\subsubsection{Assumptions}

The following assumptions are made in developing the portion of the SISMP for residues.

1. Dose rates associated with the residue stabilization effort will be manageable given the WHC/DOE administrative limit of 1,500 mrem exposure per year. A dose evaluation, discussed below, will be completed to confirm this assumption or to identify the changes needed to achieve an acceptable dose.

2. Most of the miscellaneous solid residue material will be low plutonium assay. The material will be stabilized to $1000^{\circ} \mathrm{C}$ with a $0.5 \mathrm{wt} \%$ LOI, necessary for compliance with the DOE Standard DOE-STD-3013-94 (pending the issuance of a residue standard). The stabilized material will be packaged to the DOE standard as soon as the DOE Standard packaging system is available at PFP.

3. Operations will be on a 24-hour-per-day, 5-day-per-week basis, and personnel and funding will be provided to support this level of effort.

4. Facility modifications needed for packaging and storage of plutonium containers to DOE Standard DOE-STD-3013-94 and the residue standard currently under development are scheduled to be operational by June 1998. This will permit most of the polycube material to be packaged and stored to the DOE Standard as it is produced.

\subsubsection{Issues and Problems}

The following issues and problems have been identified that could affect the ability of the residue stabilization program to meet its program objectives.

1. Until the processing and terminal cleanout activities are fully defined and an integrated system dose evaluation is completed in June 1996, worker exposure cannot be accurately determined. Results of the dose evaluation may identify a need for additional shielding, automation, or an entirely new system to meet the WHC/DOE administrative guideline of 1,500 mrem per year.

2. An upgrade of the PFP Analytical Laboratory is needed to facilitate characterization of the plutonium-bearing material for processing or disposal, to provide better process 
control of the various stabilization operations, and to meet WIPP and RCRA criteria for TRU waste.

3. DOE approval of a strategy to discard a significant fraction of the miscellaneous solid residue as TRU solid waste will expedite completion of the stabilization effort. A rationale and supporting economic analysis will be submitted in September 1995 to promote this strategy. Currently, approval for discard rests with DOE-HQ. Moving this authority to the Field Office would hasten discard. At the same time, space allocations in the WIPP must be made to ensure that a new problem is not created.

\subsubsection{Alternatives/Impacts}

A detailed evaluation of processing alternatives was conducted in association with the Environmental Assessment conducted for the current sludge stabilization effort. This evaluation concluded that no reasonable alternatives are available to thermally treating plutonium-bearing sludges for stabilization. For safety reasons, high-organic bearing sludges will have to be treated for organic destruction by hydrolysis before furnace treatment. Restraints imposed by the DNFSB Recommendation 94-1 schedule preclude development, design, and construction of a new, customized process system. Shipment of the material to another DOE site for processing is currently not possible due to the reactive nature of the material under present shipping regulations. Much of the plutonium-bearing material in inventory at PFP, including sludges, can most economically be discarded as TRU solid waste. Engineering analyses, currently underway to further this discard alternative, will be submitted to RL by September 1995 for approval.

The only viable alternatives for miscellaneous solid residues are thermal stabilization and vault storage, and treatment and discard as TRU solid waste. Characterization of the residues may indicate pretreatment requirements such as grinding to support requirements for calcium metal stabilization, but no other mainline process, such as a new, specialty processing facility, is available within the time constraints of this program.

Redesign and modification of an existing continuous calciner is discussed in the metals and oxides section of this report. The projected schedule for this system may make it infeasible for supporting the miscellaneous solid residues. The continuous calciner may, however, result in elimination of the need for the new glovebox and the associated three furnaces. The decrease in capacity resulting in eliminating these three furnaces would be more than compensated for by the increased capacity of a continuous system.

\subsubsection{Technology Development}

The ongoing stabilization (sludges and ashes) effort will provide muffle furnace technology to support stabilization of other plutonium-bearing materials. Hydrolysis of organic-bearing materials has been practiced at PFP and elsewhere and needs no specific development. Coordination with LANL is ongoing to determine the viability of thermal stabilization of sand, slag, and crucible as well as fluoride bearing items. The current technology for 
pyrolysis of polycubes is adequate to direct the design of modifications to the existing system and provide a safe and reliable operation.

\subsection{METALS AND OXIDES}

\subsubsection{Scope}

This material category includes the PFP's current inventory of plutonium metals and oxides material of greater than $50 \mathrm{wt} \%$ plutonium that meets the Hanford Site's existing storage criteria (stabilized to $450{ }^{\circ} \mathrm{C}$ with a $1.0 \mathrm{wt} \% \mathrm{LOI}$, also called interim stable). This category covers approximately 2,999 items, containing approximately $2,600 \mathrm{~kg}$ of plutonium, will require additional stabilization and repackaging. While the majority of PFPs metals have a heat output that mandates they be transformed to oxides, a portion of the metals will only require repackaging.

\subsubsection{Remediation Objectives}

The objective is to transform the plutonium metal and oxide materials to a stable form, typically oxide, suitable for 50-year storage. This will be done concurrently with the treatment and repackaging of the interim stable residues. The material in this category has a plutonium content of $>50 \mathrm{wt} \%$ and is covered by DOE Standard DOE-STD-3013-94. This material will either be stabilized and repackaged to the DOE criteria or simply repackaged to the DOE criteria depending on its level of stability.

\subsubsection{Remediation Process}

Stabilization will be done in muffle furnaces after stabilization of the sludges and reactive solid residues (an evaluation will be conducted during FY 96 to determine if there is justification based on dose or cost effectiveness to use a continuous calciner).

Re-stabilization of the oxides would require only the high-temperature soak period in the furnace, and the throughput of the nine new furnaces would increase to about $2,300 \mathrm{~kg}$ per year on this material. Processing through a continuous calciner would stabilize up to 2,600 $\mathrm{kg}$ of bulk material per year. As with the other material, the stabilized product from the oxide feed would be allowed to cool in a controlled environment and then would be packaged to DOE Standard DOE-STD-3013-94. Material processed before the new packaging system was operational would have to be repackaged.

\subsubsection{Schedule Objectives}

Evaluation and thermal modeling of the two existing continuous calciners at PFP are scheduled to start in September 1995 with a feasibility determination completed by March 1996 with the objective of selecting one of these for supporting the stabilization effort. Redesign of the existing calciner (either HC-9B or RADTU) is expected to take approximately nine months. Concurrent with the redesign would be the cleanout of the 
existing system, safety analysis, and applicable NEPA activities. Procurement of required hardware is expected to take an additional three months. Installation and testing would take six months, followed by a three-month readiness review. Startup of the system is therefore possible no earlier than July 1998.

If it is not feasible for the existing continuous calciners to be modified, a new system would be evaluated and line item funding would need to be reprogrammed. During the period between when the residue stabilization activity ends and a continuous calciner is available for operation, starting in January 1999 stabilization of the oxides would proceed in the muffle furnaces.

Stabilization or repackaging of metals will be completed by September 2000 . The oxides will be re-stabilization upon the completion of stabilization of the reactive residues (FY 98) with completion in early 2002. Material processed after June 1998 will be packaged and stored to DOE standard criteria. A small amount of metal and oxides, processed before June 1998, will have to be repackaged to the DOE standard.

\subsubsection{Assumptions}

The following assumptions are used in the development of the management plan for the metal and oxides schedule.

1. The DOE project to provide the packaging and storage capability per DOE Standard DOE-STD-3013-94 will be completed in time to allow a June 1998 startup date at PFP. This is an expedited schedule requiring close management and appropriate resource availability.

2. Information from the inventory characterization will be available to permit timely decisions regarding disposition of the various items of metal and oxides.

\subsubsection{Issues and Problems}

The following issues and problems have been identified that could affect the ability of the stabilization program for metal and oxides to meet its objectives.

- Until the processing activities are defined and an integrated system dose evaluation is completed in June 1996, worker exposure cannot be accurately determined. Results of the dose evaluation may identify a need for additional shielding, automation, or an entirely new system to meet the WHC/DOE administrative guideline of $1,500 \mathrm{mrem}$ per year. This dose assessment may indicate that the batch furnaces are acceptable as-is or with minor modifications, thus eliminating the need for a continuous system. 


\subsubsection{Alternatives/Impacts}

There is no reasonable alternative at PFP to thermal stabilization of the oxides. This implementation plan includes two parallel activities (batch and continuous systems). Due to its continuous operation and higher throughput, the continuous calciner is the preferred method. Should the continuous calciner prove impractical, the furnaces have the capability to complete the stabilization within the eight-year time frame. Shipment of metal and oxides to another DOE site with processing capability is a viable alternative.

\subsubsection{Technology Development}

No technology development needs are identified for this material.

\subsection{ACTIVITIES COMMON TO ALL PLUTONIUM-BEARING MATERIAL TYPES - SUPPORT SYSTEMS}

\subsubsection{Scope}

This category includes all support systems necessary to implement this portion of the Hanford SISMP, but which are not directly related to a specific material category. Current infrastructure (basic facility services such as power, ventilation, heat, etc.) at the PFP are in need of upgrades to support facility operations for the next 8 to 15 years of stabilization, cleanout, and transition to a deactivated state. Approximately half of PFP's current inventory of plutonium-bearing material is expected to be covered by DOE Standard DOE-STD-3013-94, the remainder will be covered by the standard currently under development. To implement DOE-STD-3013-94 (as well as the residue standard under development), PFP will need to: (1) install a new packaging system; (2) modify the existing vault storage arrays to accept the new package; and (3) develop a new material container meeting the requirements of DOE Standard DOE-STD-3013-94. The existing safeguards and security (SAS) systems will need to be modified as well to support the new package and/or to maintain reliability for the next 20 years of storage. The current laboratory capabilities at the Hanford Site are insufficient to support the necessary analysis of TRU materials and wastes. Depending on the outcome of the DOE Materials Disposition PEIS, additional upgrades to the $2736-Z$ and $2736-Z B$ facilities may be required.

\subsubsection{Support Objectives}

The objectives of these support systems are: to enable the facility to transform the plutonium-bearing materials to a stable form, typically oxide, suitable for long-term storage; to provide the necessary hardware to implement the DOE-STD-3013-94 packaging standard; and to maintain a safe and compliant facility. Additionally, these support systems will enable the facility to discard those items that are determined to be waste in full compliance with state and federal regulations. 


\subsubsection{Support Systems Descriptions}

The required support system modifications can be broken down into four categories:

1. Installation of the packaging and loadout system and associated vault modifications to allow for the implementation of DOE-STD-3013-94 and the to-be-issued residue standard.

2. Upgrades to the existing PFP laboratories to enable complete characterization of plutonium-bearing materials and waste as needed.

3. Upgrades to the existing facility infrastructure to enable the facility to support plutonium handling in a cost-effective manner. These upgrades are not fully defined but include replacement of the steam system with electric service, replacement of old ventilation control equipment with more reliable and maintainable systems, and modification of facilities as required to support the general transition and deactivation of the PFP complex.

4. Modernization of the existing SAS systems to provide maintainable remote inventory and surveillance capabilities.

All proposed modification projects are being screened to ensure that they support the general transition of the PFP complex towards deactivation and are necessary to achieve an acceptable level of reliability.

Due to the scope of the work required and the associated cost, one line-item-funded project is envisioned for the new packaging system and associated vault modifications. The SAS system modernization is expected to be expense-funded replacement-in-kind. The laboratory upgrades are expected to be within the constraints of a general plant project (GPP).

\subsubsection{Schedule Objectives}

Engineering work on the facility upgrades and SAS modernization is well underway. The SAS project is currently funded for FY 1995 and FY 1996 with contingent funding in FY 1997. An estimate will be prepared for the laboratory upgrades with the goal of obtaining GPP funding for 1997. The new packaging system and associated vault modifications will require additional engineering prior to development of a validated cost estimate.

Reprogramming of an existing line item (FY 1998, \$18 million for PFP SAS upgrades) will be required to meet the programmatic goal of completion of the repackaging by May 2002. The packaging system can, accordingly, be available in June 1998 . 


\subsubsection{Assumptions}

The following assumptions are used in developing this portion of the Hanford SISMP, addressing the support system schedule.

1. Approximately half of the plutonium-bearing material will be above $50 \mathrm{wt} \%$ of plutonium and will therefore be stored in the Hanford Site's organic-free material container until the capacity exists to package to DOE-STD-3013-94 criteria.

2. That the consolidated development and procurement activity currently underway at DOE-HQ will provide a functional system which PFP can procure in October 1997 (FY 98 funding) and have fully operational by June 1998.

\subsubsection{Issues and Problems}

No specific issues or problems have been identified in this area. The DOE standard packaging system is being developed through a consolidated development and procurement effort.

\subsubsection{Alternatives/Impacts}

The development and procurement of the packaging system is being coordinated by DOEHQ. No alternatives are being considered locally. Hanford will continue to stabilize material and store it to Hanford's current criteria (using an organic free material container starting in May 1996) until such a time as the standard packaging system is fielded.

\subsubsection{Technology Development}

The standard packaging system is being developed by DOE-HQ as a consolidated, complexwide activity.

Hanford will need to stabilize material prior to the fielding of the DOE standard DOE-STD3013-94 packaging system. The development of a material container must meet the requirements of DOE-STD-3013-94 and residue standard currently under development, and be capable of guaranteeing the LOI of the stored material. This material container must also fit into Hanford's existing food-pack-style container for interim storage. This container must be free of organics while still guaranteeing a leak tight seal. The container must also have a tattle-tale system to indicate if a leak has occurred. The Hanford Site's material container will guarantee that material does not have to be re-stabilized before repackaging to DOE standard criteria. 


\subsection{DOSE EVALUATION}

The preliminary stabilization and cleanup rates in this SISMP do not consider the radiation dose on the workers, and it is questionable that individual doses can be held within the administrative limit of 1,500 mrem per year with all systems operational and at projected staff levels. A dose evaluation engineering study on the overall system will be performed to address this issue. The study will:

1. Map the existing dose rates in the areas of the 234-5Z Building where processing gloveboxes are, or will be, located. This mapping will identify the background radiation levels associated with operations in these areas and also pinpoint sources of radiation that should be removed.

2. Model the individual processing operations and calculate worker dose based on:

- The location, amount, and composition of the source material contributing to the radiation field

- The geometry and logistics of worker movements relative to the radiation field

- The production demands on the processing system.

3. Based on the above evaluations:

- Calculate the total dose commitment associated with operation of the entire system, based on the production projections

- Calculate the annual dose per person based on the proposed staffing plan for each processing facility

- Recommend remote monitoring and handling improvements as necessary to meet ALARA requirements

- Recommend remediation measures, i.e., shielding or reconfiguration, to bring the worker dose down to the administration limit

- Recommend other dose-reducing measures such as sequencing the items to be stabilized so that the higher dose items are spread through out the stabilization campaign instead of bunched together.

The study will be completed in June 1996 in time for the recommendations to be implemented. Preliminary results from the study will be available beginning in December 1995 to help orient design work then in progress. 


\subsection{CHARACTERIZATION OF PLUTONIUM-BEARING MATERIALS}

Containers of plutonium-bearing materials shall be classified according to their contents and container integrity into one of the following categories:

- Stable and suitable for continued, indefinite storage as is

- Stable and suitable for indefinite storage after repackaging

- Needs thermal stabilization and packaging for indefinite storage

- Needs denitration, thermal stabilization, and packaging for indefinite storage

- Needs pyrolysis, thermal stabilization, and packaging for indefinite storage

- Can be packaged and disposed of as waste.

This characterization shall be done by:

- Reviewing the documentation on contents of each container

- Assessing the material and container in accordance with the above categories

- Where necessary, sampling and analyzing the contents of the container to make the above determination

This effort will provide the basis for the sequencing of items to ensure continued safe storage as well as to ensure the proper stabilization process is used on each item. This effort will also provide valuable information relative to dose to workers. The dose information will be used to help ensure worker doses do not exceed the administrative control limits.

\subsection{PLUTONIUM FINISHING PLANT FINAL SAFETY ANALYSIS REPORT REVISION}

The PFP received approval for the FSAR after a four-year approval process. The scope of processing and cleanout activities listed in the DNFSB Recommendation 94-1 SISMP will necessitate a revision to the PFP FSAR. This revision will need to be expedited through the DOE approval cycle in order to meet the programmatic goals.

\subsection{INTERNATIONAL ATOMIC ENERGY AGENCY INTERACTION}

Currently, one of PFP's vaults is monitored by the IAEA. Plans exist to bring the rest of PFP's vaults under IAEA monitoring prior to completion of the implementation of this plan. 
While it is believed that necessary arrangements can be made to allow the stabilization to continue as planned, there is a significant potential for schedule delays.

\subsection{WORK PLAN}

Cost, schedule, and technical baselines for the plutonium-bearing materials covered by this SISMP are provided by this document. Cost and schedule performance will be monitored on a monthly basis, and variance reports will be submitted to RL by the PFP Program Manager on the seventh of each month beginning June 7, 1995. Each task or activity is covered by a schedule bar on the GANTT chart and by a WBS Cost Account. A PFP Cost Account Manager is assigned to each activity and is responsible for cost and schedule performance under that activity. The PFP Cost Account Manager will report his performance to the PFP Program Manager on the first of each month. The variance report by the PFP Program Manager will cover any variation between the baseline and actual schedule or cost account with explanation and plans for necessary corrective action. The technical baseline is subject to formal change control and cannot be changed without the change control process.

The Program baseline will be reviewed and changed, as necessary, every six months starting in August 1995. The formal change control process will govern any change to the Program baseline.

\subsection{PLUTONIUM VULNERABILITY CORRECTIVE ACTIONS}

\subsubsection{Scope}

Hanford has 35 identified Plutonium Environmental, Safety, and Health Vulnerabilities. The vulnerabilities range from institutional problems to specific hardware problems. Many of the identified vulnerabilities will be corrected through the stabilization and packaging activities required by the DNFSB Recommendation 94-1 Implementation Plan, others will be corrected as a part of plutonium handling facilities transition (deactivation) to the Environmental Restoration Program, the remaining can not be fully corrected until environmental restoration is complete. Table 3-3 outlines the vulnerability and relationship to the three methods of mitigation.

\subsubsection{Mitigation Activities}

\subsubsection{Stabilization and Packaging Activities}

Vulnerabilities associated with stabilization and packaging of plutonium bearing materials will be mitigated by the efforts outlined in sections 3.2 through 3.5 of this Management Plan. All activities will be completed by May 2002. 


\subsubsection{Transitioning of Plutonium Handling Facilities Activities}

Vulnerabilities associated with residual contamination in facilities will be mitigated through facility transition and eventual deactivation. The end result of this effort will be facilities that are acceptable for turnover to the Environmental Restoration Program. Those activities listed with completion dates listed in Table 3-3 are also shown on this Management Plan schedule. Only the cost associated with the cleanout and deactivation of the PFP are included in the total program costs included in this Management Plan. Budget data have only been developed for activities through the year 2004.

\subsubsection{Environmental Restoration Activities}

Vulnerabilities that can not be mitigated by the operating contractor will be mitigated during environmental restoration activities. These vulnerabilities typically require facility demolition or other large scale corrective measures. Appropriate compensatory measures are in place to ensure the vulnerabilities do not pose undue risk to the workers, public, or environment. No schedule or budget data are available at this time. 
Table 3-3. Hanford Plutonium ES\&H Vulnerabilities

\begin{tabular}{|c|c|c|c|}
\hline $\begin{array}{l}\text { Plutonium } \\
\text { Vulnerability } \\
\text { Number }\end{array}$ & Vulnerability Title & Mitigation Process & $\begin{array}{c}\text { Estimated } \\
\text { Completion Date }\end{array}$ \\
\hline RL-1.0.1 & $\begin{array}{l}\text { Competing Priorities for } \\
\text { Experienced Personnel }\end{array}$ & N/A & N/A \\
\hline RL-1.0.2 & Penetration of Glovebox Barriers & Facility transition/ deactivation & FY 2004 \\
\hline RL-1.0.3 & $\begin{array}{l}\text { Isolation and Layaway of } \\
\text { Gloveboxes }\end{array}$ & Facility transition/ deactivation & FY 2004 \\
\hline RL-1.0.4 & $\begin{array}{l}\text { Polymer-Based Panels and } \\
\text { Glovebox Windows }\end{array}$ & Facility transition/ deactivation & FY 2004 \\
\hline RL-1.0.5 & $\begin{array}{l}\text { Penetration of Contamination } \\
\text { Containment/Fixative }\end{array}$ & Facility transition/ deactivation & FY 2006 \\
\hline RL-2.0.1 (PNL) & $\begin{array}{l}\text { Insufficient Knowledge of } \\
\text { Packaging Configuration and } \\
\text { Nature of Material in Building } \\
324\end{array}$ & $\begin{array}{l}\text { Stabilization and packaging } \\
\text { efforts directly related to the } \\
\text { DNFSB Recommendation }\end{array}$ & TBD \\
\hline RL-2.0.2 (PNL) & $\begin{array}{l}\text { Insufficient Knowledge of } \\
\text { Packaging Configuration and } \\
\text { Nature of Material in Building } \\
325\end{array}$ & $\begin{array}{l}\text { Stabilization and packaging } \\
\text { efforts directly related to the } \\
\text { DNFSB Recommendation }\end{array}$ & TBD \\
\hline RL-2.0.3 (PNL) & $\begin{array}{l}\text { Insufficient Knowledge of } \\
\text { Packaging Configuration and } \\
\text { Nature of Material in Other PNL } \\
\text { Buildings }\end{array}$ & $\begin{array}{l}\text { Stabilization and packaging } \\
\text { efforts directly related to the } \\
\text { DNFSB Recommendation }\end{array}$ & TBD \\
\hline RL-3.0.1 & $\begin{array}{l}\text { Criticality Accident During } \\
\text { Deactivation or D\&D Activities } \\
\text { Due to Abnormal Conditions }\end{array}$ & Facility transition/ deactivation & FY 2006 \\
\hline RL-3.1.2.1 & $\begin{array}{l}\text { 232-Z Incinerator Contamination } \\
\text { Release Due to Seismic } \\
\text { Destruction of Building }\end{array}$ & Facility transition/ deactivation & December 1995 \\
\hline RL-3.1.2.2 & $\begin{array}{l}\text { Release of Plutonium Holdup in } \\
\text { Exhaust Ducts Downstream of } \\
\text { 234-5Z Final HEPA Filters Via } \\
\text { 291-Z Stack Exhaust Blowers }\end{array}$ & Facility transition/ deactivation & FY 2006 \\
\hline RL-3.1.2.3 & $\begin{array}{l}\text { Concrete Block Wall and Doors } \\
\text { at the South End of the PRF } \\
\text { Canyon Fail DBE Analysis }\end{array}$ & $\begin{array}{l}\text { Re-analysis has shown wall and } \\
\text { doors are adequate as-is. }\end{array}$ & Complete \\
\hline RL-3.1.3.1 & $\begin{array}{l}\text { Hydrogen Generation in Solution } \\
\text { Storage Containers Which Are } \\
\text { Not Vented }\end{array}$ & $\begin{array}{l}\text { The suspect containers were } \\
\text { inspected and vented as required. }\end{array}$ & Complete \\
\hline RL-3.1.3.2 & $\begin{array}{l}\text { Plutonium Stored in Unstable } \\
\text { Forms }\end{array}$ & $\begin{array}{l}\text { Stabilization and packaging } \\
\text { efforts directly related to the } \\
\text { DNFSB Recommendation }\end{array}$ & January 2000 \\
\hline
\end{tabular}


WHC-EP-0853 REV. 1

\begin{tabular}{|c|c|c|c|}
\hline $\begin{array}{l}\text { Plutonium } \\
\text { Vulnerability } \\
\text { Number }\end{array}$ & Vulnerability Title & Mitigation Process & $\begin{array}{c}\text { Estimated } \\
\text { Completion Date }\end{array}$ \\
\hline RL-3.1.3.3 & $\begin{array}{l}\text { Deterioration of Storage } \\
\text { Containers }\end{array}$ & $\begin{array}{l}\text { Stabilization and packaging } \\
\text { efforts directly related to the } \\
\text { DNFSB Recommendation }\end{array}$ & May 2002 \\
\hline RL-3.1.3.4 & $\begin{array}{l}\text { Insufficient Knowledge of } \\
\text { Packaging Configuration and } \\
\text { Characterization of Material }\end{array}$ & $\begin{array}{l}\text { Stabilization and packaging } \\
\text { efforts directly related to the } \\
\text { DNFSB Recommendation }\end{array}$ & January 2000 \\
\hline RL-3.1.4.1 & $\begin{array}{l}\text { Injury or Contamination During } \\
\text { PRF Canyon Entry }\end{array}$ & Facility transition/ deactivation & September 1999 \\
\hline RL-3.1.4.2 & $\begin{array}{l}\text { Reactive Chemicals in PFP } \\
\text { Gloveboxes }\end{array}$ & $\begin{array}{l}\text { Stabilization of the existing } \\
\text { inventory of sludges has been } \\
\text { completed. Any future sludge } \\
\text { that is generated during facility } \\
\text { cleanup will be stabilized soon } \\
\text { after collection. }\end{array}$ & Complete \\
\hline RL-3.1.5.1 & $\begin{array}{l}\text { Breach of Drain Lines with } \\
\text { Holdup in PFP }\end{array}$ & Facility transition/ deactivation & FY 2003 \\
\hline $\mathrm{RL}-3.1 .5 .2$ & $\begin{array}{l}\text { HF Corrosion of Exhaust } \\
\text { Ventilation Ductwork and } \\
\text { Primary Filters Servicing } \\
\text { Glovebox HC-9B and HA-46 in } \\
\text { PFP }\end{array}$ & Facility transition/ deactivation & September 1997 \\
\hline RL-3.1.5.3 & $\begin{array}{l}\text { Corrosion of Ductwork } \\
\text { Servicing Laboratories by Acids }\end{array}$ & Facility transition/ deactivation & FY 2003 \\
\hline RL-3.1.5.4 & $\begin{array}{l}\text { Worker Exposure from Exhaust } \\
\text { Ventilation Ductwork and } \\
\text { Process Vacuum System }\end{array}$ & Facility transition/ deactivation & September 1997 \\
\hline RL-3.1.6.1 & $\begin{array}{l}\text { Contamination and Exposure } \\
\text { from Cleaning } 242-Z\end{array}$ & Facility transition/ deactivation & FY 2003 \\
\hline RL-3.2.1 & PUREX Pu Residual Inventory & Facility transition/ deactivation & FY 1997 \\
\hline RL-3.2.2 & Residuals in PUREX Tunnels & $\begin{array}{l}\text { Environmental Restoration } \\
\text { Program }\end{array}$ & TBD \\
\hline RL-3.2.3 & $\begin{array}{l}\text { Release of Residual Deep Bed } \\
\text { Filter Contamination Via the } \\
\text { PUREX Main Stack }\end{array}$ & $\begin{array}{l}\text { Environmental Restoration } \\
\text { Program }\end{array}$ & TBD \\
\hline RL-3.2.4 & $\begin{array}{l}\text { Inadvertent Breach of Gross Pu } \\
\text { Contamination Beneath Paint in } \\
\text { the PUREX White Room }\end{array}$ & Facility transition/ deactivation & FY 1997 \\
\hline RL-3.3.1.1 & $\begin{array}{l}\text { Contamination Spread Resulting } \\
\text { from Loss of Control Resulting } \\
\text { from a Roof Fire at Retired } \\
\text { Facilities }\end{array}$ & $\begin{array}{l}\text { Environmental Restoration } \\
\text { Program }\end{array}$ & TBD \\
\hline
\end{tabular}


WHC-EP-0853 REV. 1

\begin{tabular}{|c|c|c|c|}
\hline $\begin{array}{l}\text { Plutonium } \\
\text { Vulnerability } \\
\text { Number }\end{array}$ & Vulnerability Title & Mitigation Process & $\begin{array}{c}\text { Estimated } \\
\text { Completion Date }\end{array}$ \\
\hline RL-3.3.1.2 & $\begin{array}{l}\text { Potential Loss of Containment } \\
\text { Integrity - Retired Facilities: } \\
\text { 222-B \& -T, 202-S, 308, 309, } \\
3706\end{array}$ & Facility transition/ deactivation & TBD \\
\hline RL-3.3.2.1 & $\begin{array}{l}340 \text { Waste Handling Complex } \\
\text { Release to Environment }\end{array}$ & Facility transition/ deactivation & TBD \\
\hline RL-3.3.2.2 & $\begin{array}{l}\text { Sand Filters at 221-B, 221-T, } \\
\text { and 202-S }\end{array}$ & $\begin{array}{l}\text { Environmental Restoration } \\
\text { Program }\end{array}$ & TBD \\
\hline RL-3.3.2.3 & $\begin{array}{l}\text { Z-9 Building Frequent } \\
\text { Contamination Outside of } \\
\text { Engineered Barriers }\end{array}$ & Facility transition/ deactivation & FY 2001 \\
\hline RL-3.3.2.4 & $\begin{array}{l}\text { Release of Plutonium from 231- } \\
\text { Z Duct }\end{array}$ & Facility transition/ deactivation & FY 1998 \\
\hline RL-3.3.2.5 & Residual Plutonium in 209-E & Facility transition/ deactivation & TBD \\
\hline RL-WGAT-1 & $\begin{array}{l}\text { Criticality and Contamination } \\
\text { Potential in Settling Tank } 241-Z \text { - } \\
361\end{array}$ & Facility transition/ deactivation & FY 2000 \\
\hline
\end{tabular}




\subsection{REFERENCES}

Bergsman, K. H., 1994, Hanford Spent Fuel Inventory Baseline, WHC-SD-SNF-TI-001, Rev. 0, Westinghouse Hanford Company, Richland, Washington.

Brown, R. L., 1995, Spent Nuclear Fuel Canister Storage Building Startup Plan, WHC-SDW379-SUP-001 (Draft), Westinghouse Hanford Company, Richland, Washington.

Conway, J. T., 1994, DNFSB Recommendation 94-1, (letter to H. R. O'Leary, U.S. Department of Energy, May 26), Defense Nuclear Facilities Safety Board, Washington, D.C.

DOE, 1993, DOE Spent Fuel Working Group Report on Inventory and Storage of the Department's Spent Nuclear Fuel and other Reactor Irradiated Nuclear Materials and the Environmental, Safety, and Health Vulnerabilities, U.S. Department of Energy, Washington, D.C.

DOE, 1994a, Plan of Action to Resolve Spent Nuclear Fuel Vulnerabilities (Phase III), U.S. Department of Energy, Washington, D.C.

DOE, 1994b, DOE Spent Nuclear Fuel Technology Integration Plan, SNFP-PP-FS-002, U.S. Department of Energy, Washington, D.C.

DOE, 1995a, Approval of Spent Nuclear Fuel (SNF) Path Forward Recommendation, (letter to A. L. Trego, Westinghouse Hanford Company, July 31), U.S. Department of Energy, Richland Operations Office, Richland, Washington.

DOE, 1995b, Approval of K Basins Sludge Disposition Strategy, (letter to A. L. Trego, Westinghouse Hanford Company, June 13), U.S. Department of Energy, Richland Operations Office, Richland, Washington.

DOE, 1995c, Plutonium Vulnerability Management Plan for the Environmental, Safety and Health Vulnerabilities Associated with the Department's Plutonium Storage, DOE/EM-0199, U.S. Department of Energy, Washington, D.C.

Ecology, EPA, and DOE, 1994, Hanford Federal Facility Agreement and Consent Order, as amended, Washington State Department of Ecology, U.S. Environmental Protection Agency, and U.S. Department of Energy, Olympia, Washington.

Fulton, J. C., 1994, Hanford Spent Nuclear Fuel Project Recommended Path Forward, WHC-EP-0830, Westinghouse Hanford Company, Richland, Washington. 
Idaho, 1995, Public Service Company of Colorado v. Batt, No. 91-0035-S-EJL (Distric Court of Idaho, October 17, 1995), (consent order).

Lytle, J. E., 1994, Action: Approval of Path Forward for N-Reactor Spent Nuclear Fuel Interim Storage, (letter to T. P. Grumbly, November 9), U.S. Department of Energy, Washington, D.C.

O'Leary, H. R., 1995, DNFSB Recommendation 94-1 Implementation Plan, (letter to J. T. Conway, Defense Nuclear Facilities Safety Board, February 28), U.S. Department of Energy, Washington, D.C.

WHC, 1995a, Hanford Site Spent Nuclear Fuel Project Management Plan, WHC-SD-SNFPMP-011, Westinghouse Hanford Company, Richland, Washington.

WHC, 1995b, Integrated Process Strategy for K Basins Spent Nuclear Fuel, Volume I: Strategy \& Recommendations (Draft), WHC-SD-SNF-SP-005, Westinghouse Hanford Company, Richland, Washington.

WHC, 1995c, Spent Nuclear Fuel Project Technical Baseline Document, WHC-SD-SNF-SD003, Rev. 0, Westinghouse Hanford Company, Richland, Washington.

WHC-CM-5-8, Plutonium Finishing Plant Administration, Volume 1, Westinghouse Hanford Company, Richland, Washington. 
WHC-EP-0853 REV. 1

APPENDIX A

FACILITY DESCRIPTIONS 
WHC-EP-0853 REV. 1

This page intentionally left blank. 


\section{APPENDIX A: FACILITY DESCRIPTIONS}

\section{$105-\mathrm{KE}$ and 105-KW Basins}

The 105-KE and 105-KW Basins are located in the 100 Area of the Hanford Site. The basins are constructed of reinforced concrete walls and floors. The dimensions of each basin are 125 feet long (38 meters), 67 feet wide ( 20 meters), and 21 feet deep ( 6 meters). The 105-KE Basin walls are a constant thickness of $69 \mathrm{~cm}$. The 105-KE Basin has neither sealant nor liner on its concrete. The 105-KW Basin has an epoxy sealant, but no liner.

Each basin is enclosed by a one story steel framed building. The building also houses the water treatment and cooling systems. The roof structure of the steel frame includes a monorail fuel transport system. A personnel floor grating system covering the entire basin, is suspended from the roof.

Water levels are maintained in the $105-\mathrm{K}$ Basins at a minimum of $3 \mathrm{~m}$ above the irradiated fuel to cool the fuel and provide radiological shielding for personnel working in the facility. The water retention boundary extends into the auxiliary pits located on the east and west ends of the basins. The water in each basin is recirculated through a closed loop water-cooling system using mechanical chillers. Filters and an ion exchange system maintain basin water clarity and remove radionuclides. Used filters and spent ion-exchange system components are disposed of at the Hanford 200 Area Low-Level Waste Burial Grounds.

The fuel is stored in canisters on the bottom of the basins in single stacked storage racks. The canisters are approximately $74 \mathrm{~cm}$ high, have two cylindrical barrels which are approximately $23 \mathrm{~cm}$ in diameter, and normally contain 14 fuel elements. A significant fraction of the fuel has damaged cladding which occurred at reactor discharge or during subsequent fuel handling, or resulted from uranium metal oxidation during storage. The loss of cladding integrity allows soluble and gaseous fission products to be released into the canister water. The canisters used in the 105$\mathrm{KE}$ Basin do not have lids and thus allow free exchange of water between the canister and the basin. Some of the canisters in the 105-KE Basin also have screen bottoms. All of the canisters in the 105-KW Basin have closed lids and bottoms.

Using hoists and separately attached lifting rods, canisters can be moved along an underwater path which corresponds to the route of the interconnecting network of slots built into the floor-grating covers. The canisters can be shifted to and from the storage basins into the abutting pits or pickup station for subsequent unloading, loading, reviewing, or inspection operations as needed.

In the 105-KE Basin, a significant amount of sludge has accumulated on the floor. The sludge consists of zirconium oxide, iron oxide, concrete grit, and other materials 
that have mixed with fission products and fuel pieces, the fuel pieces having escaped from open storage canisters or remaining from previous fuel encapsulation activities.

The 105-K Basins each currently have about $25 \%$ unused capacity (assuming no stacking), although encapsulation of the 105-KE fuel and accumulated sludge would eliminate the unused capacity in the 105-KE Basin. Fuel enrichment only up to $0.947 \%$ is allowed in the $105-\mathrm{KE}$ Basin because of the sludge accumulation on the basin floor.

Access to the $105-\mathrm{K}$ Basins is by rail. Cask handling capability at the basins are similar and fairly restrictive. Crane capacity is 27 metric tons. Casks must be loaded under water and must be less than $2.6 \mathrm{~m}$ tall. The cask transfer pit is $2.1 \mathrm{~m}$ by $2.8 \mathrm{~m}$, but framework within the loading pit reduces the free clearance to $1.5 \mathrm{~m}$ by $1.2 \mathrm{~m}$. Also, only the transfer pit located on the south side of the basin is functional.

T Plant

The 221-T Building is a $259 \mathrm{~m}(850 \mathrm{ft})$ long by $21 \mathrm{~m}(68 \mathrm{ft})$ wide by $23 \mathrm{~m}(74 \mathrm{ft})$ high reinforced concrete canyon building. T Plant was originally designed for recovery of plutonium from defense production reactor fuel. The building consists of the canyon, three galleries, one shielded craneway and a "headend" facility. The canyon area consists of 37 cells and one railroad tunnel entrance/exit. Shielding walls made of 3-m-thick $(9 \mathrm{ft})$ reinforced concrete separate the cells from the electrical and pipe galleries. The operating gallery is separated from the canyon deck by a $1.5-\mathrm{m}-$ thick ( $5 \mathrm{ft}$ ) concrete wall that extends $3 \mathrm{~m}(9 \mathrm{ft})$ towards the ceiling. Most of the cells are covered by four $2-\mathrm{m}$-thick $(6 \mathrm{ft})$ reinforced-concrete blocks. The original equipment has been removed from some to the cells. The 221-T Building canyon pool cell (Cell 4) was modified for the storage of the PWR Core II irradiated fuel. This concrete cell has a fabric liner between white concrete and grey reinforced concrete.

Cell 4 is adjacent to the railroad tunnel and contains a $4 \mathrm{~m}$ wide by 8.4 meter long pool with a capacity of about 200,0001 . Filtered, demineralized raw water is used for the initial pool fill. An installed demineralizer provides make-up water to replenish pool water lost by evaporation. An ion exchange column, installed in a radiation shield near the pool, is provided for removal of radioactive contamination from the pool water and for maintaining water quality. Two pumps, each capable of providing a flow of $38 \mathrm{1} / \mathrm{min}$, are installed for recirculation of pool water through the ion exchange column and the water chillers. Two chillers, each capable of removing up to $133,000 \mathrm{~kJ}$ per hour of radioactive decay heat, are installed near the pool. One pump and one chiller will normally be on standby. A catwalk is placed $1.5 \mathrm{~m}$ above the pool to allow access to the pool for sampling and maintenance. All fuel must be handled remotely. The water depth in the pool cell is 5.8 meters (19 feet). Each assembly is stored vertically in a separate compartment of a rectangular metal rack. 


\section{Fast Flux Test Facility}

Until recent defueling of the FFTF reactor, FFTF assemblies were stored within several different systems at FFTF. Irradiated assemblies were stored within the reactor core, the in-vessel storage (IVS), the interim decay storage (IDS), and the fuel storage facility (FSF). Some irradiated fuel pins were shipped off-site for detailed examination and a few assemblies were temporarily located within the IEM cell, while they were examined. Irradiated assemblies were handled remotely and those within the reactor core, the IVS, the IDS, and the FSF were cooled with liquid sodium. Assemblies were routinely moved between the reactor core, the IVS and the IDS; but once placed in the FSF, fuel assemblies were not reinserted into the reactor. The following paragraphs describe storage at each of the FFTF systems although the reactor has been permanently defueled.

The reactor contains the fueled and non-fueled assemblies, and provides radiation shielding, cooling, and instrumentation to allow safe operation. The reactor is also equipped with instrumentation which permits monitoring of assembly temperature and coolant flow, but is not part of the plant safety system.

The reactor core contains fueled, non-fueled, and control rod assemblies, as well as radial reflectors and shield components, which function together to create a controlled, fast neutron environment. The core consists of nine rows of vertical elements arranged in a hexagonal array. The active zone consists of the 91 positions of the six inner rows. It can be loaded with as many as 82 fueled and non-fueled-test assemblies, with the other nine positions occupied by control rods. The active zone is surrounded by three rows of reflector assemblies.

The IVS is located within the reactor core barrel, but outside of the core region. Fuel stored in the IVS enables the reactor core to be reconfigured during an operating cycle, without opening the reactor vessel. The IVS consists of three storage modules within the reactor, each serving one-third of the reactor core. Each module provides 19 natural-circulation, sodium-cooled receptacles for core components. Each IVS module consists of a top and bottom plate welded together with an elliptical shaped body. The storage receptacles are cylindrical tubes supported by the top and bottom plates. Heat is rejected through the same primary coolant system that services the reactor core.

The IDS is located within the reactor containment building, but outside of the reactor core. It provides a controlled environment for temporary storage of irradiated fuel and other core components between irradiations in the reactor core. The IDS also provides temporary storage of new assemblies and other core components enroute to the core. The IDS is in a rectangular, steel-lined concrete cell. The IDS consists of a rotatable storage basket, contained in a sodium filled, argon inerted, stainless steel primary vessel. A carbon steel guard tank surrounds the primary vessel to help ensure adequate sodium cooling even if the primary vessel were to leak. The 
atmosphere outside the primary vessel, but within the concrete cell, is nitrogen which also serves as a heat transfer medium to control the cell temperature.

There are 122 storage positions for fueled components and other core components, arranged in five concentric circles. The outer four circles can store 112 of the $3.7 \mathrm{~m}$ long core components while the inner circle can store ten special $12 \mathrm{~m}$ long non-fuel assemblies. In order to accommodate these different length assemblies, the IDS has a relatively small cylindrical lower section connected to a larger upper section. The lower cylinder is approximately $6 \mathrm{~m}$ long and $0.25 \mathrm{~m}$ in diameter. The upper section is a cylinder $3.8 \mathrm{~m}$ long and $3.7 \mathrm{~m}$ in diameter. The transition between these sections is a conical section approximately $2 \mathrm{~m}$ long. The primary vessel contains about $60,000 \mathrm{~kg}$ of sodium.

The decay heat of an assembly placed in the IDS must be no greater than $10 \mathrm{~kW}$, while the total inventory decay heat is limited to $155 \mathrm{~kW}$. Decay heat is dissipated by either the primary sodium system for the reactor or the backup nitrogen cooling system.

The FSF is located at the FFTF, in a separate building from the reactor containment building. It provides a controlled environment for longer term storage of irradiated fueled components and other core components. The FSF consists of a primary storage vessel, several closed loop systems and supporting facilities. The fuel is held in a rotatable storage rack contained in a sodium filled, argon inerted, carbon steel primary vessel. A surrounding carbon steel guard tank ensures adequate sodium containment and cooling, in the event of a primary vessel leak. The FSF is housed in a building of standard industrial above-grade construction and reinforced concrete below-grade construction.

The primary vessel contains 466 positions for assemblies and Ident 69 containers (containers of irradiated assembly fuel or blanket pins) arranged in concentric circles, although only 380 are currently usable due to criticality considerations. The primary vessel is about $6.9 \mathrm{~m}$ in diameter and $7.3 \mathrm{~m}$ long. It is supported by a flange at the top and contains about $100,000 \mathrm{~kg}$ of sodium. The decay heat of an assembly placed in the FSF must be no greater than 1.4 kilowatts.

Decay heat is removed from the stored materials by natural circulation of the vessel sodium. The sodium transfers heat to two separate sodium-potassium heat transfer loops, which reject the heat to the atmosphere through a natural draft heat exchanger in each loop. Each loop has a heat removal capacity of $205 \mathrm{~kW}$.

The FSF is designed to interface with the FFTF fuel-handling equipment to facilitate insertion and removal of fueled and non-fueled core components, as are all the FFTF facilities where fuel is held. The FSF makes use of the Bottom Loading Transfer Cask and the FFTF floor valve for these operations. 


\section{$\underline{324 \text { Building }}$}

The 324 Building accommodates the study of chemical processes from laboratory to pilot scale at levels of radiation varying from natural background to megacuries (MCi). It also permits examination and mechanical testing of irradiated specimens. The 324 Building contains the laboratory, support facilities including hot cells, and offices required to pursue technical laboratory operations.

The 324 Building is $62.5 \mathrm{~m}$ by $71.6 \mathrm{~m}$ in plan and $13.7 \mathrm{~m}$ in height above ground level. The 324 Building has a partial basement, first, second, and partial third floors for a total of approximately $9,450 \mathrm{~m}^{2}$ of floor area. The foundation structure is poured-in-place reinforced concrete. The superstructure is constructed from insulated, fluted-steel, industrial panels supported on a structural steel frame.

Fuel in the 324 Building is stored primarily in two hot cells:

- B Cell - is $6.7 \mathrm{~m}$ wide $\times 7.6 \mathrm{~m}$ long $\times 9.3 \mathrm{~m}$ high. The cell is $3.0 \mathrm{~m}$ below grade and extends $6.2 \mathrm{~m}$ above ground level. The floor and walls are lined with stainless steel. The cell is serviced by two remotely operated cranes with 2.7 and 5.4 metric tons capacity, respectively. These cranes travel through a $5.2 \mathrm{~m}$ high doorway into the neighboring Airlock Cell.

The cell is surrounded on three sides by operating galleries on the first and second floors and on two sides by a gallery at the basement level. Shielding walls at the three operating faces of the first-floor operating gallery level are $1.2 \mathrm{~m}$ thick, high density concrete. Each of these walls has a large viewing window, two master-slave manipulators, and a number sleeved holes for supplying services to the cell. There are two cubicles on the west wall of BCell. The remaining cell-to-gallery shielding walls are $1.4 \mathrm{~m}$ and $1.2 \mathrm{~m}$ thick normal concrete at the first and second floors and basement, respectively.

- D Cell - is $4.0 \mathrm{~m}$ wide $\times 6.4 \mathrm{~m}$ long $\times 5.2 \mathrm{~m}$ high and is located directly over C-Cell. The floor between the cells is $0.6 \mathrm{~m}$ thick with a removable floor plug. The short east and west walls are $1.7 \mathrm{~m}$ thick normal concrete and border on the Cask Handling Area and operating gallery, respectively. The long north wall is $1.1 \mathrm{~m}$ thick normal concrete and borders on the Airlock Cell. The long south wall is $1.2 \mathrm{~m}$ thick, high density concrete and borders the operating gallery.

D-Cell is similar to other RE cells (A and C cells) and has two shielding windows, two pair of master-slave manipulators, a remote viewing periscope, and closed-circuit television. The floor is lined with stainless steel; the walls are lined with mild steel with a corrosion-resistant coating. Access to the cell is via the Airlock Cell or through a small transfer port communicating with a glove box. This glovebox is used for experiments using microcuries of 
radioactive materials in encapsulated form and connects to the ventilation system. A small $10 \mathrm{~cm}$ pass-through port is available for one-way movement of materials into the cell. All normal operations in D-Cell are done remotely; all services and facilities are provided at the front face and connected through shielding plugs or offset piping.

Although there are rail spurs in the 300 Area, no direct rail access to the 324 facility is available. Any movement of materials to or from the facility would need to be done by truck. The facility has an overhead crane with a capacity of 27 metric tons, which could be used to move the fuel inside the building. There are also some restrictions to movement of heavy or large objects within the facility, specifically, the floor loading capacity is limited to $978 \mathrm{~kg} / \mathrm{m}^{2}$. The hot cell air lock height is also somewhat limited.

The fuel is stored dry in racks within the cells. Air provides the necessary cooling and is filtered by high efficiency particulate air filters before discharged through an exhaust stack. The fuel is handled remotely with cranes and master-slave manipulators.

\section{$\underline{325 \text { Building }}$}

The 325 Building was designed to provide space for radiochemical research. The building, located in the 300 area of the Hanford Site, houses the 325-A Radiochemistry Facility and the Shielded Analytical Laboratory. The 325 Building consists of 1) a central portion (completed in 1953) containing general purpose laboratories modified for low-level radiochemical work by provision of special ventilation and work enclosures; 2) a south (front) wing containing office space, locker rooms, a lunch room and maintenance shops; and 3) east and west wings provided with shielded enclosures and remote manipulators for high-level radiochemical work.

The central portion of the building is 59.1 by $59.8 \mathrm{~m}$ on three floors (basement, ground, and second) and contains over 100 laboratories and offices. The south wing is 22.6 by $40.5 \mathrm{~m}$ on two floors and contains offices, a conference room, a machine shop, a lunch room, and rest rooms. The east wing (325A), known as the HighLevel Radiochemistry Facility, housing the process research hot cells, truck lock, and manipulator repair, is 14.6 by $39.6 \mathrm{~m}$ with a 12.2 by $12.8 \mathrm{~m}$ service area/truck lock addition. The west wing (325B), known as the Shielded Analytical Laboratory, is 16.2 by $16.5 \mathrm{~m}$ and houses additional process research hot cells. Small fuel pieces are stored in the hot cells in both the High-Level Radiochemistry Facility and the Shielded Analytical Laboratory.

The High-Level Radiochemistry Facility contains three interconnecting cells (A-, B-, and $\mathrm{C}-\mathrm{Cell}$ ) and supporting facilities for work with megacuries of radionuclides. Two of the cells have inside dimensions of $1.8 \mathrm{~m}$ wide by $4.6 \mathrm{~m}$ high by $2.1 \mathrm{~m}$ deep; the 
third cell has inside dimensions of $4.6 \mathrm{~m}$ wide by $4.6 \mathrm{~m}$ high by $2.1 \mathrm{~m}$ deep. The three cells are enclosed in a $25 \mathrm{~m}$ by $14.6 \mathrm{~m}$ steel-framed, reinforced-concrete structure. These cells are shielded with walls of $1.2 \mathrm{~m}$ thick, high-density concrete on the front and sides and $0.9 \mathrm{~m}$ thick, high-density concrete on the back. Remote operation of the cell equipment is performed in the "front face" operating gallery; movement of materials takes place in the rear support gallery. The rear support gallery also provides access to the cells. The cells are ventilated by air drawn from the rear face gallery and exhausted through testable HEPA filters. The cells are constructed on the first-floor level and supported by heavy reinforced-concrete piers, columns, and pilasters. The basement level contains exhaust ducting, HEPA filters, and other miscellaneous services to the cells. The front side contains manipulators, service ports, and high-density lead-glass windows having equivalent shielding to that of the walls. Each cell has a $45.7 \mathrm{~cm}$ thick Meehanite iron door shielding the main entrance and other smaller entry ports on the back.

B-Cell currently contains a core extruder and analytical measuring equipment used for the tank waste characterization program. A-Cell and C-Cell contain contaminated equipment from canceled programs, for which clean-up is not currently funded. Currently A-Cell and C-Cell are also being used to characterize tank waste.

The Shielded Analytical Laboratory contains six interconnecting "hot" cells and two separate hot cells. The interconnecting cells are 1.7 by $1.7 \mathrm{~m}$ compartments inside shielding walls. These compartments are divided into three groups of two compartments each, separated by hollow $10.2 \mathrm{~cm}$ thick sheet metal dividers. The shielding walls on the east and north sides of the cells are $30.5 \mathrm{~cm}$ of Meehanite iron.

Shielding walls on the west and south sides are $66 \mathrm{~cm}$ of magnetite concrete. The east side of each compartment is equipped with two manipulators and with highdensity, lead-glass viewing windows having the same shielding effect as the walls. These compartments are used for analytical chemistry operations on small amounts of highly radioactive materials such as samples of single-shell tank waste. Operations within the cells are by manipulator or other remote equipment. The other two hot cells are in a separate room and are two all-metal cells. One cell is $2.0 \mathrm{~m}$ long by $1.4 \mathrm{~m}$ wide by $2.5 \mathrm{~m}$ high, inside dimensions, with $15 \mathrm{~cm}$ thick walls and roof. The other cell is $1.7 \mathrm{~m}$ long by $1.5 \mathrm{~m}$ wide by $1.5 \mathrm{~m}$ high, inside dimensions, with $15 \mathrm{~cm}$ thick walls and roof. This cell sits on a pedestal that is $81 \mathrm{~cm}$ above the floor. Both cells have shielded viewing windows, two master-slave manipulators, an access door, and a pass-through port.

Although there are rail spurs in the 300 Area, no direct rail access to the 325 facility is available. Any movement of materials to or from the facility would need to be done by truck. The 325A Wing has an overhead crane with 27 metric tons capacity and the $325 \mathrm{~B}$ Wing has an overhead crane with 2.7 metric tons capacity, which could be used to move the fuel inside the building. 


\section{Building}

The 327 Building is a single-story structure with a partial basement. Maximum dimensions are $65.5 \mathrm{~m}$ long by $42.7 \mathrm{~m}$ wide by $9.8 \mathrm{~m}$ tall and the building is roughly cruciform in shape. The total work area is approximately $2,330 \mathrm{~m}^{2}$ with $929 \mathrm{~m}^{2}$ of laboratory and work areas; $195 \mathrm{~m}^{2}$ of offices; $223 \mathrm{~m}^{2}$ of storage areas; and $975 \mathrm{~m}^{2}$ of common areas containing ventilation and auxiliary equipment. The building framework is welded steel. The exterior walls are fluted steel insulated panels. The primary operating area is on the main floor and includes 11 hot cells, two small shielded cells, two small water pools, the area around the cells (the canyon), and the bays connected to the canyon in which auxiliary operations are performed.

A 13.5 and a 18 metric ton bridge crane are used to transfer casks containing radioactive structural materials or fuel from the receiving area to the cells or between the cells, and for general lifting and transfer service in the canyon.

Materials unaffected by air are examined and tested in shielded cells with an air atmosphere. Cells A through I are shop-fabricated from high-density cast iron (Meehanite) having a specific gravity of 7.3. The base, walls, and top cover are fitted together by a groove-dowel, lock-together design. The shielded cells rest on a reinforced concrete floor. If direct access is required, a wall may be removed to permit maintenance or to make changes in process or handling equipment.

Most operations in the cells are performed with manipulators. Spaced symmetrically about the iron cell walls are interchangeable plugs that lock in place by expanding retaining rings. Services and viewing ports are supplied through special plugs.

The two lead-brick shielded cells are used for density determination and for deposition of surface films for electron microprobe studies.

The Special Environmental Radiometallurgy Facility or SERF Cell provides an examination and storage facility with a nitrogen atmosphere for specimens that may be affected by air. The facility consists of an upper operating area and a lower storage area. A detachable shielded enclosure at the north end, with access to the operating cell, houses a remote metallograph for photomicrography, microhardness testing, and sample viewing at high magnification. Two airlocks provide access for entry or removal of test materials, supplies, equipment, and waste without compromising the integrity of the cell atmosphere. Operating equipment is designed to be located entirely within the cell, and operations are performed with manipulators.

The SERF storage cell is located in the basement and is connected to the operating area by a transfer tube. There is a thickness of $1.75 \mathrm{~m}$ of concrete between the ceiling of the SERF storage cell and the floor of the main SERF cell above.

Shielding consists of $0.6 \mathrm{~m}$ of concrete on all sides with $10 \mathrm{~cm}$ of lead shielding on the north and west sides and $27 \mathrm{~cm}$ of steel on the operating (east) face. The south 
side is inaccessible since it is adjacent to a building support wall. A manipulator is provided to permit positioning and retrieval of materials in the storage area. Three storage racks are located in the cell, on the wall opposite and on the two walls adjacent to the operating face of the cell. The racks accommodate $6.4 \mathrm{~cm}$ diameter by $10.2 \mathrm{~cm}$ long sample cans and other smaller containers. The three storage racks contain a total of 460 locations.

The purpose of the wet storage basins is to store incoming material before examination and out-going material before shipment. The larger storage basin is $3 \mathrm{~m}$ wide by $4.6 \mathrm{~m}$ long by $5.2 \mathrm{~m}$ deep, with an $2.6 \mathrm{~m}$ deep underwater shelf, $1.2 \mathrm{~m}$ wide, across the width of the basin. The smaller basin is $1.8 \mathrm{~m}$ wide by $2.4 \mathrm{~m}$ long by $3 \mathrm{~m}$ deep. A canal $0.5 \mathrm{~m}$ wide by $3 \mathrm{~m}$ deep connects the large and small basins, to facilitate movements of material from one storage basin to the other. Two $225 \mathrm{~kg}$ jib cranes, one serving each basin are used to transfer materials in the basins. A transfer tube connects Cell $A$ and the small basin. A mechanical sample carrier in the tube provides for sample transfers between cells and the basins. Water quality in the basins is maintained by molecular filters and mixed bed deionizers.

Several racks are located in the large basin for storage of fuel and structural materials. There is one breeder reactor fuel pin storage rack, capable of holding up to 200 pins in a rigid array. The rack consists of $76 \mathrm{~cm}$ long, $2.5 \mathrm{~cm}$ diameter stainless steel tubes arranged in a $4 \times 50$ rectangular array. The tubes are welded into a box-like structure with a stainless steel frame and side panels. The rack sits on the basin floor with the storage tubes oriented vertically. A lifting ring is permanently attached to the top of the rack. The entire rack is $168 \mathrm{~cm}$ long, $61 \mathrm{~cm}$ wide, and 76 $\mathrm{cm}$ high. A wall rack for containers holding individual pins or structural specimens and a peg rack for holding tubing or duct material are located on the north wall of the large storage basin.

The irradiated fuel is stored in several different locations within the Postirradiation Testing Laboratory of 327 Building. The intact fuel pins are stored in a rack in a water basin and in various facility hot cells. The partial fuel pins and small fuel pieces are stored in small cans on shelves in the thirteen hot cells, and in a small dry storage vault.

\section{Building}

The 308 Building, located in the 300 Area of the Hanford Site, is a two story structure constructed of reinforced concrete, concrete block, and steel siding, with the interior finished in painted plaster. The interior support pillars are reinforced concrete. The floors are reinforced concrete with a painted or vinyl surface. The roofs are constructed with a steel decking covered with insulating concrete and topped with a built-up, 20 year life, tar and gravel coating. The interior of the building consists of office space, laboratory facilities, gloveboxes, fuel element assembly and 
storage areas, X-ray facilities, the Neutron Radiography facility, and maintenance areas.

The building was designed as a multipurpose nuclear facility for the development and fabrication of nuclear reactor fuel containing plutonium. Originally constructed in 1961 , the building has been expanded several times to reach the current $6,600 \mathrm{~m}^{2}$ of floor space. Of this area, the first floor laboratories comprise 2,249 $\mathrm{m}^{2}$; second floor laboratories and personnel corridor comprise $950 \mathrm{~m}^{2}$; the maintenance shops, service areas, and ventilation equipment comprise $1,480 \mathrm{~m}^{2}$; the 308 Annex comprises $870 \mathrm{~m}^{2}$; and an attached office building comprises $1,050 \mathrm{~m}^{2}$.

A large fuel assembly area was added in 1970. Over 2,000 fuel configurations were produced in the 308 Building before 1976, many for a variety of offsite reactors. Between 1975 and 1979, the 308 Building was expanded with the addition of the 308 Annex and the Training Reactor Isotopics General Atomics (TRIGA) Reactor. Since 1976, the main mission of the building has been the preparation and quality assurance (QA) verification and testing of all FFTF fuel assemblies.

The Neutron Radiography Facility (NRF) consists of that portion of the 308 Building Annex which houses the TRIGA Reactor and associated neutron radiography equipment. The NRF consists of the reactor hall, control room, and irradiated fuel cask handling room. The main feature of the facility is the TRIGA Mark I reactor, which is housed in a cylindrical stainless steel water pool, $2.8 \mathrm{~m}$ in diameter and $6 \mathrm{~m}$ deep. Although connected to the 308 Building by a 7.6 meter long airlock, they do not share a common wall. The annex walls are constructed of steel reinforced concrete block, and the roof is a weather-sealed steel deck.

The TRIGA reactor in the NRF was used primarily as a source of neutrons for the NRF to generate radiographs of fabricated fuel pins. It was used to a lesser extent in neutron activation analysis and as training platform for other reactors. The TRIGA reactor was installed in the NRF in the late 1970's and operated intermittently for 13 years. Currently there are no plans to use the 308 Building or the NRF for nuclear fuel development or fabrication. The facility is being placed in long term shutdown configuration and the NRF is no longer needed. The TRIGA reactor has been shutdown since May 1989. The fuel elements are being stored in subcritical racks around the periphery of the reactor pool. Following the transfer of all fuel elements to the storage racks, the status of the reactor was changed to that of a fuel storage basin per the DOE approved shutdown plan for the TRIGA reactor. The reactor is now referred to as the TRIGA Fuel Storage Basin.

Although there are rail spurs in the 300 Area no direct rail access to the 308 facility is available. Any movement of materials to or from the facility would need to be done by truck. The 308 Building has an overhead crane with 4.5 metric tons capacity, which could be used to move the fuel inside the building. 


\section{Area Plutonium Finishing Plant}

Eighty-four grams of 93.2 percent enriched uranium fuel stored at the 2736-ZB Building at the Plutonium Finishing Plant in the 200 West Area of the Hanford Site. The fuel was irradiated at the University of Washington. The fuel is a uraniumaluminum alloy with aluminum cladding. The fuel is contained in a partial assembly of six plates, which are 65.1 centimeters in length, 7.24 centimeters in width and 0.18 centimeters in thickness. The six fuel plates are stored in one 55 gallon drum. The fuel has had very little exposure; its burnup is effectively zero, with surface dose rates of $0.3 \mathrm{mr} / \mathrm{hr}$ gamma and $0.8 \mathrm{mr} / \mathrm{hr}$ beta plus gamma.

There are 7.8 kilograms of plutonium fuel from the LAMPRE at Los Alamos National Laboratory stored in three EBR II casks within the yard area at PFP. The casks are located within a protective concrete structure.

\section{West Area Low-Level Burial Ground}

There are 17.2 kilograms of uranium from the TRIGA at Oregon State University stored at the 200 Area Low Level Burial Grounds. The uranium hydride fuel in the TRIGA fuel element is mixed with zirconium hydride (8.5\% uranium and $91.5 \%$ zirconium). Six or seven of the aluminum clad fuel assemblies are contained in each of 13 lead-lined 55 gallon drums. The average weight of the drums is 1,043 kilograms. Overall dimensions of the TRIGA fuel elements are 3.73 centimeters (1.47 inches) in outside diameter and 72.1 centimeters ( 28.4 inches) in length. The fuel was received at Hanford during 1987 and is covered with soil in Trench 7 in $218-\mathrm{W}-4 \mathrm{C}$.

The 218-W-4C Burial Ground contains trenches with flat, gravel bottoms, and with asphalt bottoms. The 218-W-4C Burial Ground holds the 13 lead-lined 55 gallon drums in trench 7, covered with at least four feet of soil.

The current storage container, called the TRIGA ${ }^{\oplus}$ Standard Fuel Element Storage Drum is composed of three layers. The outside skin is made from a 17C DOT Specification Container, 49 CFR 178.115, sometimes called a 55 gallon drum. The intermediate container is a carbon steel, 14-inch diameter, schedule 80 pipe section, with a bottom welded closure and a top bolted closure. Normal weight concrete is poured between these two containers. The third and inner container is a 5-inch diameter, schedule 40 pipe. The void between the two pipes is filled with lead shot with lead castings top and bottom. 
WHC-EP-0853 REV. 1

This page intentionally left blank. 
various solutions in forms suitable for disposal as TRU waste is not expected to be determined before September 1995. Other important activities are:

1. Contents of the two organic solution containers will be evaluated for immobilization in small batches or for disposal as TRU solid waste. A decision as to the disposition of this material is expected in September 1995. If disposal is recommended and approved by DOE, disposal would be completed within 90 days of DOE authorizing the disposition of the material.

2. The chloride and miscellaneous solutions (including fluoride solutions) are being stabilized in the PFP Process Support Laboratory as a result of the test program to demonstrate alternative technologies for stabilization of solutions. The chloride and miscellaneous solutions will be stabilized by September 1995. The technology development program will be complete by March 1996.

3. Development of the Hanford interim storage container started in May 1995 with a functional container being available by May 1996. The DOE standard packaging system is currently scheduled to be ready in June 1998 (See Section 3.5).

\subsubsection{Assumptions}

The following assumptions were considered in the development of the portion of the Hanford SISMP for solutions:

1. Dose rates associated with the solution stabilization effort will be manageable given the WHC/DOE administrative limit of 1,500 mrem exposure per year. A dose evaluation, discussed below in Section 3.6, will be completed to confirm this assumption or to identify the changes needed to achieve an acceptable dose. This concern is being reviewed by the PFP EIS and a record of decision is due in June 1996.

2. The current laboratory development program will identify and resolve any technology and equipment development issues and will serve as an adequate basis for design of the selected process system.

3. Facility modifications needed for packaging and storage of plutonium containers to the DOE Standard (DOE-STD-3013-94) are scheduled to be operational, with special funding dispensation, by June 1998. The Hanford container, suitable for overpacking to the DOE Standard, will be available by May 1996. Stabilized high-assay ( $>50 \mathrm{wt} \%$ plutonium) solution material produced after the latter date will be retrieved from storage and overpacked for 50-year storage. No further processing or repackaging will be required. Vault modifications will be required to store the DOE standard container. 
4. Operations will be on a 24-hour-per-day, 5-day-per-week basis, and personnel and funding will be provided to support this level of effort.

\subsubsection{Issues and Problems}

The following issues and problems have been identified that could affect the ability of the solution stabilization program to meet its objectives:

1. Until the processing activities are defined and an integrated system dose evaluation is completed in June 1996, worker exposure cannot be accurately determined. Results of the dose evaluation may identify a need for additional shielding, automation, or an entirely new system to meet the WHC/DOE administrative guideline of 1,500 mrem per year.

2. An upgrade of the PFP Analytical Laboratory is needed to facilitate characterization of the plutonium-bearing material for processing or disposal, to provide better process control of the various stabilization operations, and to meet Waste Isolation Pilot Plant (WIPP) and RCRA criteria for TRU waste.

3. To expedite the disposal process, approval authority for deleting safeguards for items designated as waste needs to be transferred to the Field Offices. Additionally, to avoid problems in the future associated with the ultimate disposal of the TRU waste, the Field Offices must be given a space allocation in WIPP.

\subsubsection{Alternatives/Impacts}

Currently, six processes to be utilized in the stabilization of aqueous solutions are being evaluated in the PFP Process Support Laboratory. Two of these processes are preferred pending final laboratory results expected by the end of 1995; one of these methods will be selected at that time as the preferred option to be discussed in the PFP EIS:

1. A continuously operated vertical calciner that will produce a solid plutonium oxide product from aqueous nitrate feed. The calciner product would be further stabilized in a muffle furnace.

2. A batch precipitation/filtration system that will produce a filter cake suitable for thermal stabilization in a muffle furnace.

Neither of the above processes is suitable for the organic solutions. The only practicable alternatives are to immobilize the solution in a solid absorbent and package the material as TRU solid waste, or to stabilize the solutions in very small batches using thermal stabilization. The latter alternative would require a safety appraisal to establish the safe batch size. The issue of discarding plutonium-bearing material as TRU waste is expected to be resolved by September 1995 with the approval of an engineering evaluation of the 


\section{DISTRIBUTION}

\section{Number of Copies}

\section{ONSITE}

14

U.S. Department of Energy-

Richland Operations Office

R. A. Almquist

N2-36

A. J. Colburn (5)

A5-58

D. C. Langstaff

K8-50

E. D. Sellers

S7-41

D. W. Templeton (5)

R3-79

Public Reading Room

$\mathrm{H} 2-53$

3 Pacific Northwest Laboratory

J. H. Jarrett P8-34

D. K. Kreid

K9-21

Hanford Technical Library

P8-55

38 Westinghouse Hanford Company
A. B. Carlson
$\mathrm{T} 4-02$
G. B. Chronister
T5-50
G. J. Cox (5)
T5-50
J. C. Fulton
R3-11
E. W. Gerber
R3-86
M. W. Gibson
T5-55
S. Guttenberg
N2-53
K. R. Herzog (5)
T5-50
T. E. Huber
T5-50
R. K. Hulvey
$\mathrm{N} 2-33$
S. L. Magnani
R3-85
R. L. McCormack
R3-86 
WHC-EP-0853 REV. 1

Westinghouse Hanford Company (cont'd)

M. J. Monthey

R3-86

A. N. Praga (10)

R3-86

J. M. Steffen

$\mathrm{N} 1-47$

E. C. Vogt

T5-50

J. C. Womack

R3-86

SNF-PF

R3-11

OSTI (2)

A3-36

Central Files

A3-88

$$
\begin{aligned}
& \text { Evd Date } \\
& 2-23-96
\end{aligned}
$$

